University of Baltimore Law ScholarWorks@University of Baltimore School of Law

\title{
Legal Accountability in an Era of Privatized Welfare
}

Michele E. Gilman

University of Baltimore School of Law, mgilman@ubalt.edu

Follow this and additional works at: http://scholarworks.law.ubalt.edu/all_fac

Part of the Social Welfare Law Commons

\section{Recommended Citation}

Legal Accountability in an Era of Privatized Welfare, 89 Cal. L. Rev. 569 (2001)

This Article is brought to you for free and open access by the Faculty Scholarship at ScholarWorks@University of Baltimore School of Law. It has been accepted for inclusion in All Faculty Scholarship by an authorized administrator of ScholarWorks@University of Baltimore School of Law. For more information, please contact snolan@ubalt.edu. 


\title{
California Law Review
}

\begin{tabular}{lll}
\hline \hline Vol. 89 & May 2001 & No. 3 \\
\hline
\end{tabular}

Copyright $\odot 2001$ by Califomia Law Review, Inc.

\section{Legal Accountability in an Era of Privatized Welfare}

\author{
Michele Estrin Gilman $\dagger$
}

TABLE OF Contents

Table of Contents

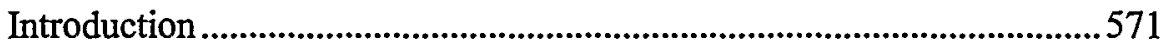

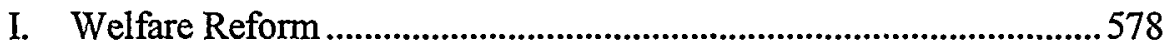

II. Privatization in Context: History and Modern Trends........................581

A. History of Public and Private Welfare Provision ..........................581

1. Early American History .........................................................582

2. The Nineteenth Century......................................................582

3. The Twentieth Century ........................................................584

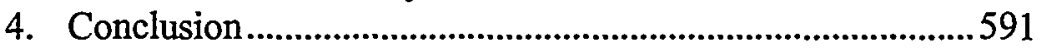

B. New Directions in Welfare Privatization .....................................591

C. The Broader Privatization Movement ..........................................594

III. Privatization and Accountability ....................................................595

A. The Arguments for and Against Privatization..............................596

B. The Empirical Evidence: The Necessity of Competition.............598

1. Entrenchment........................................................................599

2. Difficulties in Defining Tasks and Measuring Performance 600

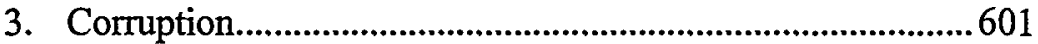

C. Legal Aspects of Privatization ....................................................602

Copyright (O) 2001 Califomia Law Review, Inc. Califomia Law Reviw, Inc. (CLR) is a California nonprofit corporation. CLR and the authors are solely responsible for the content of their publications.

$\dagger$ Visiting Assistant Professor, University of Baltimore School of Law. B.A. 1990, Duke University; J.D. 1993, University of Michigan Law School. 1 would like to thank the members of the Mid-Atlantic Clinical Theory Workshop, and especially Rob Rubinson, for their comments on a prior draft of this Article. I would also like to thank Neil Gilman. This Article is dedicated to the memory of the Honorable Frank A. Kaufman, who taught me the power of the law to do justice. 
IV. Enforcing Due Process in a Privatized Welfare System.....................603

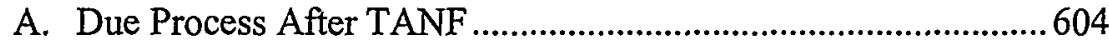

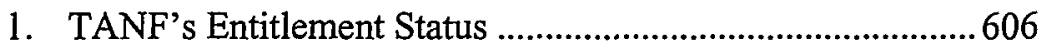

2. State Practices Under TANF ...............................................608

B. The State Action Dilemma............................................................69

1. The State Action Tests...........................................................611

2. A Critique of the State Action Tests......................................614

3. Disentangling Liability .......................................................617

4. State Action Limits on Contracting ......................................620

5. The Lower Courts' Approach ...............................................621

6. The Problem of Qualified Immunity for State Actors ...........623

V. Alternatives to Constitutional Litigation ...........................................625

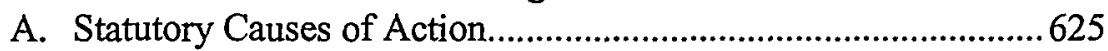

1. Federal Enforcement Mechanisms ......................................626

a. The TANF Enforcement Scheme....................................626

b. Section 1983 Statutory Enforcement ...............................627

c. Implied Right of Action ...................................................629

d. Conclusion ......................................................................6.6. 631

2. State Enforcement Mechanisms ............................................631

a. State Implied Rights of Action..........................................631

b. State APA Enforcement ..................................................632

c. State Mandamus Claims..................................................634

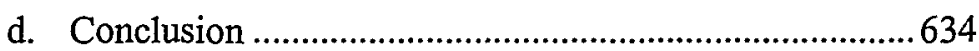

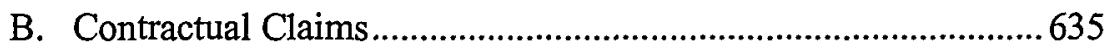

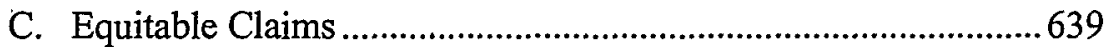

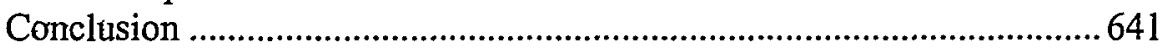




\title{
Legal Accountability in an Era of Privatized Welfare
}

\author{
Michele Estrin Gilman
}

When the federal welfare system was reformed in 1996, Congress gave States the option to contract out administration of their welfare programs to private entities. Moreover, after enactment of the welfare reform, welfare recipients are expected to work to receive benefits. This means that front-line welfare office workers must engage in intensive interpersonal counseling rather than simply confirm objective eligibility criteria and dispense checks. This results in vastly increased discretion for these front-line workers. When privatization is layered over this discretionary scheme, issues of accountability to program beneficiaries becomes significant. For over thirty years, it has been a tenet of public benefits law that due process protections attach to the government's delivery of benefits. Yet when private entities deliver the same benefits, constitutional protections may fall by the wayside. This article explores the implications of welfare privatization on welfare beneficiaries' procedural rights. It explains how the Supreme Court's current state action doctrine may well insulate private welfare providers and their state contracting partners from constitutional claims. Accordingly, the Article also explores other potential federal and state bases for enforcing accountability in welfare programs in privatized jurisdictions, ranging from statutory to contractual to equitable claims. The Article concludes that the procedural rights of welfare recipients after welfare reform are greatly diminished.

\section{INTRODUCTION}

Lockheed Martin, the defense contracting giant, has found a new business niche in an era of declining defense spending: running welfare offices. Private companies like Lockheed Martin, along with various nonprofit organizations, have become an integral part of the massive welfare reform effort started in 1996 with the enactinent of the Personal Responsibility and Work Opportunity Reconciliation Act (PRA). ${ }^{1}$ The Act, comnonly known for turning "welfare" into "workfare," is designed to push welfare recipients into the workforce. ${ }^{2}$ The PRA restructured welfare administration by eliminating the country's main assistance program for poor

1. Pub. L. No. 104-193, 110 Stat. 2105 (1996) (codified in scattered sections of 42 U.S.C.).

2. Pub. L. No. 104-193, $\$ 401,110$ Stat. 2105, 2113 (1996) (codified at 42 U.S.C. $\S 601$ ). 
families, Aid to Families with Dependent Children (AFDC), and by giving states fixed block grants for "temporary assistance for needy families," known as TANF. ${ }^{3}$ The Act also devolves significant control over welfare administration from the federal government to the states, and it further gives the states the option of devolving welfare operations to the county and city level, and to private organizations if they choose. State and local governments have eagerly embraced this new opportunity to privatize welfare in the hopes that private organizations can deliver welfare cheaper, faster, and better. ${ }^{5}$

Despite the growing privatization of social services, there has been little discussion of the ramifications of this change on welfare recipients themselves from either a practical, empirical, or legal perspective. ${ }^{6}$ While government has relied heavily on contracting with private nonprofit entities for social service delivery since the 1960s, these entities have usually been limited to providing discrete services such as job training or child care. The PRA makes two major changes to this existing scheme of public/private interdependence. First, under the PRA, private entities are allowed to run entire welfare offices. This means that, for the first time, they can perform eligibility determinations and sanction recipients for noncompliance with program requirements. Second, the PRA has opened the door for large forprofit organizations such as Lockheed Martin to enter into welfare delivery. These for-profit entities have different incentives, and more political power, than the nonprofit entities typically engaged in social service delivery in the past.

After the PRA, welfare office employees are no longer dispensers of checks. They are expected to put people to work, and this requires intensive interpersonal interactions. As a result, front-line workers have vastly increased discretion. When privatization is layered over the PRA's broad discretionary scheme, accountability issues heighten. Stories of failed social service privatization programs have already surfaced. For instance, Maryland cancelled a contract with Lockheed Martin to conduct child support enforcement in the face of service complaints after Lockheed failed to meet collection objectives. ${ }^{7}$ Likewise, Califorma cancelled a contract with Lockheed to build a statewide computer system for child support

3. See infra note 52 .

4. See infra notes 56-58 and accompanying text.

5. See infra Part II.B.

6. Some of the few exceptions include Daphne Barak-Erez, A State Action Doctrine for an Age of Privatization, 45 Syracuse L. Rev. 1169 (1995), and David J. Kennedy, Due Process in a Privatized Welfare System, 64 BROOK. L. Rev. 231 (1998). These articles, however, are limited largely to constitutional issues. See infra notes 257 and 259.

7. See Greg Garland, Lockheed Called Failure on Child Support Goals: State Announces Collection Contract Will Not Be Extended, BALT. SuN, Mar. 4, 1999, at 1B; Greg Garland, Collections of Child Aid Questioned; Lockheed IMS Defends Performance in State's Program, BaLT. SuN, Jan. 10, 1999 , at $1 \mathrm{~B}$. 
enforcement when cost projections escalated from $\$ 99$ million to $\$ 277$ million (and where Lockheed's contract limited its own liability to just $\$ 3$ million). ${ }^{8}$ Lockheed is not the only culprit of headline-grabbing malfeasance. Another big player in welfare privatization, Maximus, Inc., has its welfare contracts with New York City under criminal investigation for alleged nepotisin and corruption. ${ }^{9}$ Its contract with Connecticut to handle child care benefits for welfare families was threatened with termination because " $[h]$ nndreds of families have waited for months without receiving aid they were promised, the company has been unable to process a deluge of paperwork and its phone lines have been overloaded with pleas for help." 10

Apart from this anecdotal evidence, empirical evidence suggests that privatization is ill-fitted for the complex, long-term tasks associated with welfare delivery after the PRA. This area lacks the definable yardsticks and competition necessary to sustain accountability to taxpayers and to service beneficiaries. As a result, legal mechanisms for enforcing accountability of welfare providers are more important than ever.

Unfortunately, privatization also strips away the traditional legal methods for enforcing accountability. Under AFDC, the predecessor welfare prograin to the PRA, welfare benefits were an entitlement to which due process protections attached. ${ }^{11}$ Moreover, since beneficiaries were interacting with government bureaucrats, there was no question that state actors were involved and that due process protections therefore applied. Under the PRA, it is less clear whether welfare benefits retani their entitlement status. As a result, welfare advocates across the country are struggling with questions concerning the contimued availability of federal constitutional protections. In privatized jurisdictions, these issues are even more complex. Even if a federal constitutional right to due process remains in the receipt of welfare benefits, it is questionable whether a private entity such as Lockheed Martin will be deemed a state actor to whoin constitutional guarantees apply. ${ }^{12}$

This Article explores the implications of privatization on welfare beneficiaries' due process rights. The piece focuses on procedural rights for several reasons. To begin with, fair procedures increase the likelihood of success of substantive claims for benefits. Under the PRA, states and localities have increased discretion in running their welfare programs. As a result, welfare recipients must rely less on statutes and regulations as a

8. Willian D. Hartung \& Jennifer Washbum, From Warfare to Welfare: Lockheed Martin Wants to Make Huge Profits from Social Programs, Balt. Sun, Mar. 22, 1998, at 1F.

9. See infra notes 206-209 and accompanying text.

10. Jonathan Rabinovitz, In Connecticut, a Privately Run Welfare Program Sinks Into Chaos, N.Y. TIMEs, Nov. 24, 1997, at B1.

11. See infra Part IV.A.

12. See infra Part IV.B. 
basis for asserting their substantive rights, and more on fact-based advocacy focusing on their individual claims. ${ }^{13}$ For example, if a welfare recipient disagrees with a caseworker's decision to sanction the recipient for failing to participate in a job training program, the recipient will have to contest that decision through the hearing process. Perhaps the recipient failed to attend job training because of a lack of child care or transportation, or because of domestic abuse. ${ }^{14}$ That individual needs a fair and impartial forum in which to be heard. Moreover, the fair hearing process serves as a constraint on arbitrary and capricious decision making by front-line workers, who now possess more discretionary power than ever. Finally, fair hearing procedures provide empowerment and dignity to welfare recipients, a group traditionally voiceless. ${ }^{15}$

The implications of privatization for the due process rights of recipients are best illustrated by the experiences of real people navigating the choppy waters of welfare reform. In August 1998, Lue Garlick was cut off from public benefits because New York's Office of Employment Services claimed that she did not go to a required work assignment on one day four months earlier. ${ }^{16}$ Although she had indeed worked that day (failing only to sign out), she lost the fair hearing challenging her termination of benefits because she was unsure of what the judge expected her to prove. ${ }^{17}$ She was told she could reapply for benefits on November $16,1998 .{ }^{18}$ On November 16 , she went to a Job Center at 8:00 a.m. to reapply for cash assistance, food stamps, and Medicaid. ${ }^{19}$ By this time, she was homeless and pregnant with twins, and suffering from severe anemia and low blood pressure. ${ }^{20}$ She informed the receptionist that she had no food or money and needed to apply for expedited food stamps as well as Medicaid benefits so that she could buy prenatal vitamins and medication for her low blood pressure. ${ }^{21}$ The woman at the information window told her that there were no more expedited food stamps and that she would have to be in the "system"

13. Alan W. Houseman, Civil Legal Assistance for the Twenty-First Century: Achieving Equal Justice for All, 17 YALE L. \& PoL'Y REV. 369, 386-87 (1998).

14. Although many welfare recipients do not appeal adverse decisions (often because they are never made aware of their fair hearing rights), statistics demonstrate that those individuals who pursue appeals have a high success rate. Barbara Sard, The Role of the Conrts in Welfare Reform, 22 Clearinghouse ReV. 367 (1988). At the same time, ““[f]air' procedures cannot guarantee 'fair' results when the substantive rules thcmselves are inequitable." $I d$. at 379.

15. See Rebecca E. Zietlow, Giving Substance to Process: Countering the Due Process Counterrevolution, 75 DENV. U. L. REv. 9, 31-32 (1997).

16. Class Action Complaint I 149, Reynolds v. Giuliani, 35 F. Supp. 2d 331 (S.D.N.Y. 1999) (No. 98 Civ. 8877).

17. Id. ๆ 150 .

18. Id.

19. Id. I 151.

20. Id. ๆ 144.

21. Id. ๆ 151. 
before she could receive any food stamps or get Medicaid.22 The receptionist then gave her an envelope with many forms and told her to fill them out. ${ }^{23}$ The packet was missing an application form, and although Ms. Garlick requested the form, she was told she would have to wait. ${ }^{24}$

At about 10:00 a.m., a Job Center employee told her that the computer did not show that her sanction had been lifted and that she would have to wait five more days and return to the center on November $23 .{ }^{25}$ Again, she requested expedited food stamps, explaining that she was pregnant and anemic, but she was told to apply for them when she returned on the twenty-third. The Job Center employee then refused to return her documents, including the letter stating she was eligible to work as of November $16{ }^{26}$ When Ms. Garlick returned on the twenty-third at 8:00 a.m., the receptionist told her that she had no information about Ms. Garlick having been there on November 16, nor of her having applied for expedited benefits. She also was told that her documents had been lost, and that she would have to reapply. ${ }^{27}$

Seven hours later, at 3:00 p.m., Ms. Garlick was finally called for her interview. ${ }^{28}$ The employee told Ms. Garlick that she had only nine months left of benefits and that after those nine months were over, she would not be eligible for any assistance, including food stamps and Medicaid. ${ }^{29}$ She also told her that there were no emergency food stamps any longer and referred Ms. Garlick to a food pantry. She then gave Ms. Garlick a fifty-day Calendar of Appointments and told her that she was required to report to the Hamilton Job Center every day. ${ }^{30}$

Ms. Garlick reported to the Hamilton Job Center every day as required, from November 23, 1998 until December 3. ${ }^{31}$ During that time, she had a great deal of trouble obtaining food, and she frequently got sick with headaches and fevers. ${ }^{32}$ She went to the food pantry to which the Job Center had referred her, but because the Job Center required her to be at the center from 9:00 a.m. to 5:00 p.m., by the time she got to the pantry it usually was closed.$^{33}$ In the meantime, the Eligibility Verification Review office and the Job Center failed to coordinate her application, and thus permission granted by one office to miss an appointment for a doctor's

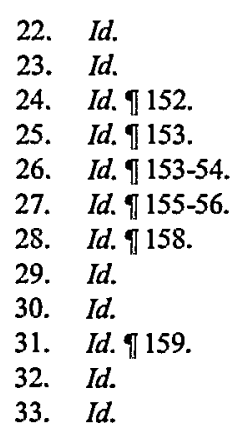


visit was not forwarded to the other office, and Ms. Garlick's application was not acted upon. Instead, she was bounced around from office to office. ${ }^{34}$ Her name was subsequently lost in the computer, and promises by the Job Center to call her back when her file was found were ignored. ${ }^{35}$ When Ms. Garlick called the Hamilton Job Center again on Deceinber 8 to see if they had found her records, she was told that they had not, that her application was rejected, and that she would have to reapply. ${ }^{36} \mathrm{Ms}$. Garlick received no benefits until December 19,1998, over one month after her mitial application. ${ }^{37}$ During that month, she went entirely without food on several occasions. ${ }^{38}$

Ms. Garlick was just one of several named plaintiffs in a class action against New York State and City welfare officials. ${ }^{39}$ The class alleged that the defendants were systematically preventing eligible individuals from obtaining food stamps, Medicaid, and cash assistance by deterring, discouraging, and preventing plaintiffs from filing applications for and receiving benefits. ${ }^{40}$ Specifically, the class alleged that the Job Centers provided false and misleading information about the availability of both ongoing and expedited assistance; refused to allow people to file applications; pressured people to withdraw their applications; denied food stamps and Medicaid benefits for reasons that apply only to cash assistance eligibility; and failed to provide written notice, including notice of hearing rights, to people who were denied benefits. ${ }^{41}$ Based on its findings of fact, drawn from the affidavits and testimony of class members, the district court issued a preliminary injunction ordering the defendants to coniply with a complex corrective plan designed to ensure that the defendants obeyed the requirements of due process as well as Medicaid, food stamp, and cash assistance statutory requirements. ${ }^{42}$

The court awarded its relief pursuant to 42 U.S.C. $\S 1983$, commonly known as Section $1983,{ }^{43}$ a civil rights statute that permits plaintiffs to enforce rights created under federal statutes and the Constitution. However, Section 1983, as well as the constitutional guarantees it enforces, applies only to state actors. ${ }^{44}$ Thus, if Ms. Garlick was applying for benefits at a

\footnotetext{
34. Id. ๆ 160-63.

35. Id. II 163.

36. Id. ๆl 164.

37. Reynolds v. Giuliani, 35 F. Supp. 2d 331, 331 , 339 (S.D.N.Y. 1999).

38. Id. at 339.

39. Id. at 331 .

40. Id. at 336-37.

41. Class Complaint at $\llbracket 4$, Reynolds (No. 98 Civ. 8877).

42. Reynolds, 35 F. Supp. $2 \mathrm{~d}$ at $347-48$. Subsequently, the court refused to modify or vacate its preliminary injunction and it certified the plaintiff class. Reynolds v. Giuliani, 2000 WL 1013952 (S.D.N.Y. 2000).

43. Id. at 337. Section 1983 is discussed in detail infra Part 1I.B.

44. See infra note 258 and accompanying text.
} 
similarly operated office run by Lockheed Martin, the question arises whether she would have any of the same protections obtained through the New York litigation. Would she have a constitutional right to due process? Would the Lockheed Martin employees be state actors? The answers to these questions will greatly impact welfare recipients in the new privatized economy of welfare.

Of course, it could be argued (and is) that the Kafka-esque conditions encountered by Ms. Garlick are the very reason why privatization should be explored as an alternative to government bureaucracies. Indeed, there is ample evidence that government welfare bureaucracies are quite capable of acting without regard to the rule of law and contrary to the interests of the disenfranchised persons they are supposed to serve. ${ }^{45}$ Yet in publicly run welfare jurisdictions, as the Giuliani litigation demonstrates, the legal system is available as a last lime of attack agamst such behavior. As this Article argues, that may no longer be true in privatized jurisdictions. Because it is not clear that private entities perform any better than public ones, privatization needs to be approached with extreme caution. Currently, it is not.

The Article proceeds as follows. Part I describes the changes mandated by the PRA and specifically addresses how the Act devolves power downward from the federal government to local institutions, both public and private. Part II sets forth the historical background of welfare $m$ this country, with an emphasis on the intertwined roles of public and private poor relief, and then explams how the landscape of welfare delivery has begun to change in the midst of the PRA. Part III discusses the arguments for and against privatization, and attempts to sort through the empirical evidence to draw some conclusions about the practical impact privatization will have upon the rights of welfare beneficiaries. Part IV explores whether constitutional protections remain for welfare beneficiaries in privatized jurisdictions. It also explains, in depth, how the Supreme Court's current state action doctrine may well insulate private welfare providers from constitutional claims. Accordingly, Part V explores other potential bases for enforcing accountability in privatized jurisdictions. Potential theories include statutory, contractual, and equitable claims; yet, all of these strategies have serious limitations. This Article concludes that under the current state of the law, welfare privatization poses great dangers to the procedural rights of beneficiaries.

45. See Susan D. Bennett, "No Relief But Upon the Terms of Coming Into the House"Controlled Spaces, Invisible Disentitlements, and Homelessness in an Urban Shelter System, 104 YALE L.J. 2157, 2157 (1995) (describing discouragement practices at the District of Columbia's Office of Emergency Shelter and Support Services, including "a waiting room ethos of undisclosed information, unexplained delays, and, above all, endless waiting, punctuated by humiliating demands for information"). 


\section{WELFARE REFORM}

In 1996, Congress passed, and President Clinton signed, the Personal Responsibility and Work Opportunity Reconciliation Act of 1996 (PRA), legislation designed to "end welfare as we know it."46 The Act eliminated the existing welfare program, Aid to Families with Dependent Children (AFDC) ${ }^{47}$ which was the subject of almost two decades of persistent criticism by policymakers, the media, and the public, who accused AFDC of causing increased government spending and of fostering dependency while failing to eliminate poverty. ${ }^{48}$ As Congress' response to these criticisms, the PRA's stated purposes are to reduce welfare dependency and out-ofwedlock births and to encourage the formation of two-parent families. ${ }^{49}$ The PRA also gives the states the flexibility to create their own programs as long as they meet these objectives. ${ }^{50}$ Accordingly, the Act changes not only the structure and funding of welfare delivery in this country, but it also attempts to change the behavior and perceived lifestyle of welfare recipients. $^{51}$

The Act eliminates AFDC's open-ended federal funding and guarantee of assistance to all eligible persons and replaces it with a capped block grant to the states, called Temporary Assistance to Needy Families

46. This was one of President's Clinton's campaign promises. Jason DeParle, The Clinton Welfare Bill: A Long, Sionny Journey, N.Y. T1MES, July 15, 1994, at A1.

47. 42 U.S.C. $\$ 601$ (repealed 1996).

48. Much of the attack on AFDC centered around a racist stereotype of the "welfare queen," an unemployed, teenage, African-American, unmarried, ghetto resident with many children. See HeLEN Hershkoff \& Stephen Loffredo, The Rights of the Poor 5-6 (1997); Kathleen A. Kost and Frank W. Munger, Fooling All of the People Some of the Time: 1990's Welfare Reform and the Exploitation of American Values, 4 VA. J. Soc. PoL'Y \& L. 3, 29 (1996). The empirical evidence does not support this stereotype. HershKofF \& LofFredo, supra, at 38-46; see also Joel F. Handler, "Ending Welfare As We Know It"-Wrong for Welfare, Wrong for Poverty, 2 Geo. J. on Fighting Poverty 3, 12-16 (1994).

The PRA also replaced the Job Opportunities and Basic Skills Training Program (known as JOBS), enacted in 1988 as part of the Family Support Act to provide incentives for AFDC recipients to work. Pub. L. No. 100-485, 102 Stat. 2343 (1988) (repealed); see infra notes 132-134 and accompanying text.

49. Pub. L. No. 104-193, $§ 401,110$ Stat. 2105,2113 (1996) (codified at 42 U.S.C. $\$ 601$ ).

50. The Act followed several years of state experimentation with welfare-to-work programs conducted pursuant to waivers from the federal government. 42 U.S.C. $\$ 1315$ (1996). Under AFDC, states had to submit a plan for Health and Human Services (HHS) approval setting forth how they would comply with their federal obligations under the law. $\S 602(a)$. However, states could obtain waivers from the "State plan" requirements for "experimental, pilot, or demonstration project[s]." $\S$ 1315. Forty-three states obtained waivers, but reformers argued that the waiver approval process was overly burdensome. These complaints, along with calls by state officials for greater state freedom, provided part of the impetus for welfare reform. See, e.g., H.R. ReP. No. 104-651 (1996), reprinted in 1996 U.S.C.C.A.N. 2183 (complaining about Ohio's experience with the waiver process; "the administration rejected four parts of the Ohio plan, or requested substantive changes that essentially gutted certain provisions....").

51. See GWENdolyn Mink, Welfare's End 103-108 (1998); Tonya L. Brito, The Welfarization of Family Law, 48 U. KaN. L. REV. 229, 234-35 (2000). 
(TANF)..$^{52}$ Although states must adhere to some national requirements, such as the PRA's requirement that all TANF recipients engage in "work activity" within two years of getting benefits and its five-year lifetime limit on the receipt of benefits, states have broad discretion to determine the conditions of eligibility for TANF funds.$^{53}$ For example, states can choose to limit the receipt of benefits to less than five years, to deny benefits to mothers who do not identify their children's biological fathers or to children born while their family is receiving benefits, to sanction families that include adults under age fifty-one who neither have nor are seeking a high school diploma, to declare noncitizens meligible for assistance, to require recipients to take drug tests, or to cut benefits to families with truant children. ${ }^{54}$ States can even choose to provide no cash benefits at all. ${ }^{55}$

By allowing states to design their own welfare programs, TANF devolves much of the authority over administering welfare from the federal government to the states. ${ }^{56}$ The federal government's role essentially is limited to reviewing state plans, monitoring the perfornance of states in putting welfare recipients to work, and sanctioning or rewarding states based on their performance. Even more significant than this federal-to-state devolution is the discretion states have under TANF to delegate authority to local governments and private nonprofit or for-profit entities. The law allows states to provide welfare services through contracts with charitable, religious, or private organizations. ${ }^{57}$ They can also choose to provide beneficiaries with certificates, vouchers, or other forms of disbursement that are redeeniable with such private organizations. ${ }^{58}$

52. Each state receives a portion of the annual $\$ 16.4$ billion block grant in an amount based upon its past welfare expenditures. Pub. L. No. 104-193, $\$ 103,110$ Stat. 2105, 2116 (1996) (codified at 42 U.S.C. $\$ 601$ ). As a capped grant, TANF ends the federal cost-sharing that covered fluctuations in welfare rolls due to economic and/or demographic changes.

53. See $\S 103,110$ Stat. at 2137 (adding new Sec. 408(a)(7) to Title IV of the Social Security Act). States can exempt up to $20 \%$ of their caseload from the five-year limit in cases of hardship. Id. (codified at 42 U.S.C. $\$ 408(a)(7)(C)$ ). They can also use their own funds to provide benefits after the five-year limit. Id.

54. Id.

55. States have the discretion to use their grants for any activity reasonably designed to achieve the Act's purposes. See id. (adding new Sec. 401 to Title IV of the Social Security Act). The stated purposes are to provide for needy children, decrease dependency and out-of-wedlock births, and encourage the formation and maintenance of two-parent families. Id.

56. Despite the Act's block grant system, at least one author has argued that the devolutionary nature of the PRA has been overemphasized given the Act's "burdensome and expensive federal requirements," for example, the maximum lifetnne limit on TANF assistance to adults of sixty months. Candice Hoke, State Discretion Under New Federal Welfare Legislation: Illusion, Reality and a Federalism-Based Constitutional Challenge, 9 Sran. L. \& Pol'y Rev. 115, 118 (1998). As a result, Hoke argues that "states with more compassionate political leadership who wish to counter the national trend may seek areas of flexibility in vain." Id. at 116.

57. Pub. L. No. 104-193, $\$ 104,110$ Stat. 2105, 2163 (1996) (codified at 42 U.S.C. $\$ 604 a$ ).

58. Id. 
Given TANF's emphasis on finding people jobs and sanctioning those who fail to work, front-line workers have a great deal of discretion, and thus, power. ${ }^{59}$ Putting welfare recipients to work necessarily requires a personalized, hands-on approach that delivering monetary benefits pursuant to objective financial eligibility criteria does not. Under AFDC, front-line workers were state employees who focused on assessing whether applicants met income and other standardized eligibility requirements. ${ }^{60}$ They might have referred welfare beneficiaries to private social service providers for job training, job placement, child care, or other discrete services, but these private agencies did not operate as the program's gatekeepers. ${ }^{61} \mathrm{By}$ contrast, front-line workers generally now engage $\mathrm{m}$ a variety of counseling and evaluative tasks. These include educating applicants about the TANF program; assessing their work histories and attempts to obtain employment; reviewing their eligibility for entitlement benefits such as SSI, Medicaid, and food stamps; determining their eligibility for cash grants, loans, or other services to divert them from the TANF program; assisting them in securing child support from noncustodial parents; helping them with job searches; assessing their child care and transportation needs, as well as doniestic violence problems or alcohol or drug abuse; drafting individualized plans to attain economic self-sufficiency; and assisting them in locating job training, GED, ESOL, and other skill building activities. ${ }^{62}$ Thus, front-line workers are being asked to shift from a people-sustaining role to a people-transforming role. ${ }^{63}$

59. See generally Mathew Diller, The Revolution in Welfare Administration: Rules, Discretion, and Entrepreneurial Government, 75 N.Y.U. L. REv. 1121 (2000) (examining changes in the adminstrative structure of the welfare system since 1996). Diller points out that many welfare programs are consolidating eligibility and counseling functions "so that each worker has several roles." Id. at 1161.

60. A study of Wisconsin's welfare reform statute, Wisconsin Works, explained the prior system: Under AFDC in 1988, an adult with a dependent child applied for assistance at the offices of the county social services agency. The application process consisted of filling out a form, providing certain documentation, and meeting with an intake worker. Payments began once the necessary information was provided to ensure that the children were the applicant's and that the family had little income, few assets, a local residence, and, in the case of two-parent families, an unemployed principal earner witb a work history. The amount of payment depended on the family's size and its income, if any.

Michael Wiseman, Urban INST., In Midst of Reform: Wisconsin IN 1997, at 4 (1999).

61. Id. at 5. For the difference between administrative structure under AFDC/JOBS and the current structure, see also David Dodenhoff, Wisconsin Policy Research INST., Inc., Privatizing WELFARE IN WISCONSIN 4-10 (1988).

62. Richard P. Nathan \& Thomas L. Gais, Implementing the Personal Responsibility AcT OF 1996: A FIRST LoOK 21 (1999).

63. Marcia K. Meyers, Gaining Cooperation at the Front Lines of Service Delivery: Issues for the Implementation of Welfare Reform, Rockefeller Reports, at http://www.rockinst.org/reports/rr07.html (June 12, 1998). Ironically, at the same time, eligibility standards at food banks and other social service organizations have tightened dramatically in the face of overwhelming demand caused by a decline in government spending on food aid. Poor people in need of these services face "[s]eemingly arbitrary eligibility rules, inflexible limits on aid and impersonal requirements." Nina Bernstein, Charity Begins at the Rule Book, N.Y. TimEs, Dec. 24, 2000, $\$ 4$, at 5. 
Thus far TANF has shrunk the nation's welfare rolls; ${ }^{64}$ however, its effectiveness in lifting the poor out of poverty is still open to debate. ${ }^{65}$ It is also unclear whether the rolls have shrunk solely because welfare recipients are working, or whether soine have been discouraged, disappeared, or have otherwise been churned off the rolls. What is clear, however, is that TANF pushes decision making downward and increases discretion at the level of the front-line worker. And where local governments have contracted out their welfare programs, that discretion rests in the hands of private persons.

II

Privatization in Context: History and Modern Trends

Privatization of social services is not new. Since the New Deal, the expansion of the federal government's role in providing welfare has been accompanied by a corresponding growth in the involvement of nonprofit providers to the point where "the Umited States relies more heavily on nonprofit organizations than on its own instrumentalities to deliver government-funded human services, and... human service nonprofits receive more of their income from government than from any other single source ... ." ${ }^{\prime 66}$ This Part aims to put the private provision of welfare in perspective, especially to demonstrate the extent to which the PRA extends welfare privatization into uncharted waters. Accordingly, this Part describes the historical background of the public and private roles in welfare relief and the growing scope of current privatization initiatives.

\section{A. History of Public and Private Welfare Provision}

Throughout American history, the poor have relied on both public relief and private charity for assistance. While the respective contributions of the public and private spheres have ebbed and fiowed over the years, often in opposition to one another, public agencies and private charities have become increasingly intertwined since the 1960s. This Part briefiy

64. Since 1994, welfare caseloads have been cut by 52\%. KATHERINE AlLEN \& Maria KiRBY, Brookings Inst., Unfinished Business: Why Cities Matter to Welfare Reform (2000).

65. See Pamela Loprest, Urban Inst., Families Who Left Welfare: Who Are They and How ARE THEY DoIng? (1999) (finding in this comprehensive study that while most women who left welfare are working, they are working in low-wage jobs and are less likely to have health insurance than other low-income mothers; one-third to one-half report serious economic struggles providing food and $20 \%$ have problems paying rent); David Kocieniewski, Study Finds Mixed Results in Reducing Welfare Rolls, N.Y. TIMES, Oct. 22, 1999, at B6 (noting that although a third of the people who left New Jersey's welfare rolls since 1997 found jobs, "two-thirds of all those who were receiving welfare when the study began in 1997 remain below the Federal poverty level of $\$ 19,000$ per year, and half have experienced serious housing problems and been evicted, forced to stay in homeless shelters or moved in with friends or family members").

66. Lester M. Salamon, Partiners in Public Service: Government-Nonprofit Relations IN THE MODERN WeLfare STATE 15 (1995). 
outlines the roles of, and connections between, public and private agencies in America's welfare history while simultaneously sketching major themes in social welfare history.

\section{Early American History}

As the population in early colonial America increased, destitution did as well, and neighborly kindness simply could not deal with the growing numbers of poor and infirm. ${ }^{67}$ In need of a more systemized response to poverty, the colonists looked to England as a model and adopted the tenets of Elizabethan Poor Law. The English Poor Law of 1601 made poor relief a matter of local responsibility and distinguished between the "unworthy" poor and the "worthy" poor, that is, those who were deemed culpable for their destitute state and those who were not. ${ }^{68}$ The colonies followed suit. ${ }^{69}$

This localized system of poor relief gradually became strained by increased migration of "strangers" into towns and cities due to immigration and job transience. As a result, by the early eighteenth century, some local governments began to call on colonial treasuries for monetary relief. ${ }^{70}$ Also around this time, private philanthropy for poor relief began in earnest, reflecting the growing accumulation of wealth by some citizens. ${ }^{11}$ In addition, private groups such as churches, fraternal societies, and benevolent organizations began providing charitable services. ${ }^{72}$ Thus, by the turn of the nineteenth century, poor relief was a mix of local, state, and private efforts, with the bulk of the relief still provided by local governments.

\section{The Nineteenth Century}

In the nineteenth century, social welfare policy took a new turn. Reformers began attacking outdoor relief (basic material assistance provided in the home), accusing it of encouraging idleness and pauperism, draining

67. See Walter I. Trattiner, From Poor Law to Welfare State: A History of Social. WELFARE IN AMERICA 15-16 (6th ed. 1999).

68. See id. at 10-12. The Poor Law, enacted in 1601 and effective for over 250 years, categorized the poor into three groups, each of which was assisted by different means: children were apprenticed, the able-bodied were put to work, and the helpless, or "worthy" poor were provided with either home relief or institutionalized. Id.; see also MichaEL B. Katz, In THE SHADOW OF THE POORHOUSE 14 (10th ed. 1996).

69. See Joel F. Handler, The Poverty of Welfare Reform 12-13 (1995). Handler cxplains that the colonies used four basic methods to relieve poverty: (1) auctioning the poor (selling them to the lowest bidder); (2) contracting the poor (paying local families to take them in at public expense); (3) indoor relief (placing the poor in poorhouses); and (4) outdoor relief (basic assistance outside the poorhouse). See also KATZ, supra note 68 , at 14 . This distinction between the worthy and unworthy poor is one that has continued to define American poor relief policies. As demonstrated by TANF, Americans have long had little sympathy for those deemed able to work, regardless of the actual availability of work. HANDLER, supra, at 30-31.

70. TRATTNER, supra note 67 , at 19-22.

71. Id. at 33 .

72. Id. at $35-36,42$. 
the public fisc, and reducing the labor supply. ${ }^{73}$ As a result, poorhouses began to dominate poor relief policy ${ }^{74}$ Both states and private organizations built and administered these social welfare institutions. Indeed, states often relied on private charities to provide certain social services, and private organizations often contributed money to states to start institutions. ${ }^{75}$ Although poorhouses mitially held promise of reform, it soon became clear that they had become warehouses of despair, and they were ultimately a failure. ${ }^{76}$ Not only did the poorhouses fail to relieve poverty, but they were plagued by corruption, filth, disorder, and disease, and they ended up costing more than outdoor relief. ${ }^{77}$

During this time, private benevolent societies also played an imcreasing role in poor relief. ${ }^{78}$ Because these societies viewed poverty as a result of poor morals, they believed that they could lift people out of poverty by improving their character. Accordingly, they embarked on campaigus to visit the homes of the poor and to provide them with moral uplift and exhortation. ${ }^{79}$

With the downfall of poorhouses, two other private alternatives to outdoor relief, both with roots in the earlier private benevolent societies, came to dominate welfare policy in the late nineteenth century: scientific charity and settlement houses. The scientific charity movement, which sought to apply the scientific principles of rationality and efficiency to welfare work, consisted of orgamizations that served as clearinghouses to coordinate relief among the many available public and private sources ${ }^{80}$ Like the earlier benevolent societies, they relied on "friendly visitors" to investigate the homes of the poor and to provide them with moral and religious

73. KaTZ, supra note 68 , at $14,23$.

74. TRATTNER, supra note 67 , at 58-59. The rise of the poorhouse mirrored the rise of other specialized institutions for the needy, such as orphanages and mental institutions. Id. at 57, 62; HANDLER, supra note 69, at 13-14; KATZ, supra note 68, at 11.

75. KATZ, supra note 68, at 10-11. Supporters claimed that poorhouses "would suppress intemperance, the primary cause of pauperism, and inculcate the habit of steady work," a habit that outdoor relief had supposedly eroded. Id. at 11,18 .

76. Id. at 24-26.

77. Id. at 26; HANDLER, supra note 69, at 16-17; TRATTNER, supra note 67, at 59-60.

78. TRATTNER, supra note 67 , at $67-68$.

79. Id. at 67, 70-71. The most prominent of these associations was the New York Association for Improving the Condition of the Poor (A.1.C.P.), founded in 1843. The A.I.C.P. relied on male visitors to "lead the dependent to self-support through instruction in the basic virtues of religious observance, thrift, hard work, and temperance." Id. at 68 . Walter Trattner has concluded that the A.I.C.P. "was no more a charitable agency than an instrument for reducing relief costs and keeping society orderly, stable, and quiet." Id. at 69. However, he points out that A.1.C.P. meinbers eventually began to understand the economic forces underlying poverty and to provide financial aid to the needy. Id. at 71 . The association thus greatly impacted later charity organization movements. Id. For a discussion of the role of volunteerism and the wide variety of active private welfare organizations in the nineteenth century, see KaTZ, supra note 68 , at 61-68.

80. TRATTNER, supra note 67 , at $91-92$. 
counseling. ${ }^{81}$ The settlement house movement, following on the heels of scientific charity, favored a preventative approach to poverty. ${ }^{82}$ Settlement house workers lived among the poor in inner-city neighborhoods and focused on strengthening communities through social and economic reforms. Central to both movements was their staunch opposition to outdoor relief. ${ }^{83}$ However, their failure to provide material aid and to recognize the underlying economic causes of poverty was one of the many reasons that scientific charity and settlement houses ultimately withered away. ${ }^{84}$

\section{The Twentieth Century}

Unable to meet increasing need, private relief shrank in importance during the first two decades of the twentieth century, and governmental assistance to the poor ascended. Reformers quickly realized that volunteerism alone could not cope with the increasing poverty engendered by the social forces of industrialization, urbanization, and immigration..$^{85}$ The plight of poor children, who were often taken from their homes and put in impersonal and expensive institutions, particularly mobilized reformers. They began to call for the care of children in their own homes. ${ }^{86}$ Accordingly, following an influential White House conference on children's issues in 1909, mothers' pensions, a form of cash assistance to women with dependent children, became the preferred form of welfare. ${ }^{87}$ The mothers' pension statutes formed the basis for the federal Aid to Dependent Children (ADC) program enacted in 1935 (later changed to Aid to Families With Dependent Children in the 1960s), the very program later abolished by the PRA.

81. This approach was riddled with contradictions that hastened its demise. As Michael Katz explains, "Over and over again, charity organizations' sponsors claimed their overriding goal was to restore the very poor to independence. Dependence on private or public charity was their great enemy. Yet, their very method taught dependence, because only an outward show of deference merited relief. Any display of independence they translated into ingratitude, and gratitude was everything." KATZ, supra note 68 , at 70 .

82. Katz, supra note 68, at 163-68; James T. Patterson, America's Struggle Against POVERTY 1900-1994, at 24-25 (1994); TRATTNER, supra note 67, at 163.

83. TRATTNER, supra note 67, at 91-92. As one reformer stated, "next to alcohol, and perhaps alongside it, the most pernieious fluid is indiscriminate soup." Id. at 92.

84. However, these two movements left their mark by eventually merging into the soeial work profession. Id. at 182 .

85. Id. at 214. At the same time, cities began to centralize their power and provide increasing municipal services to their citizens, including welfare. KATZ, supra note 68 , at 155-63. As a result, "by the late 1920 s, most cities spent three times more money than private agencies on outdoor relief." Id. at 159 .

86. TRATTNER, supra note 67 , at 215-16.

87. KATZ, supra note 68, at 215-16; TRATTNER, supra note 67, at 222-23. However, the statutes contained "suitable home" requirements, which restricted aid to "worthy" mothers and which gave local authorities great discretion in awarding beneflts. As a result, most of the aid went to "deserving" white widows, while many poor women, including those who were divorced, deserted, unmarried, or of color, received nothing. Id. at 225 . 
The 1929 stock market crash and the depression that followed left millions unemployed. ${ }^{88}$ Although private agencies and local governments attempted to aid the jobless, they were overwhelmed by the massive need. ${ }^{89}$ By 1932, one-third of the voluntary relief agencies had shuttered their doors. ${ }^{90}$ Still, President Hoover resisted a federal response to the crisis, preferring to rely on the little private charity that remained. ${ }^{91}$ By contrast, when Franklin D. Roosevelt entered the White House, he brought his support for public poor relief programs with him, and he was able to spur enactment of a series of work relief measures. ${ }^{92}$ Roosevelt got the federal government significantly involved in poor relief for the first time, a process that required the creation of massive administrative structures from whole cloth. ${ }^{93}$ Yet Roosevelt's emergency measures were meant to be temporary. ${ }^{94}$ To provide long-term security for the needy, Roosevelt pushed for enactment of the Social Security Act. Passed on August 14, 1935, the Act provided social insurance, in the forms of old-age insurance and unemployment assistance, as well as public assistance for the aged, dependent children in single-parent families, disabled children, and the blind. ${ }^{95}$ The federal government administered the old-age insurance portion of the Act (which we call Social Security), while the public assistance programs were

88. KATZ, supra note 68, at 214-17, 220. "Between 1929 and the summer of 1933, official unemployment in America climbed froin 3.2 percent to 24.9 percent." Id. at 214.

89. Id. at 214; PATTERSON, supra note 82, at 56.

90. KATZ, supra note 68, at 221-22; TRATTNER, supra note 67, at 273.

91. KATZ, supra note 68, at 222; TRATTNER, supra note 67, at 276. For an in-depth analysis of Hoover's doomed attempt to use the private sector as a substitute for a welfare state, see Ellis W. Hawley, Herbert Hoover, Associationalism, and the Great Depression Relief Crisis of 1930-1933, in With Us Always, A History of Private Chartry and Public Welfare 161 (Donald T. Critchlow \& Charles H. Parker eds., 1998). Hawley concludes that "[t]he Hooverian experience ... would seem to offer little encouragement to those who currently hope to supplant the welfare state with a private sector substitute." Id. at 175. In fact, the utter failure of voluntary relief likely paved the way for the expansive federal programs undertaken during the New Deal. Id. at 174-75.

92. TRATTNER, supra note 67, at 282-83. One of these programs, the Federal Emergency Relief Act of 1933 , made $\$ 500$ million in grants-in-aid to the states for emergency unemployment relief. The administering agency, the Federal Emergency Relief Administration, had authority to determine the extent of the grants, but the funds were distributed by states and localities. Id. at 284-85. However, the head of the agency, Harry Hopkins, issued a directive requiring that all of the grant money be handled by public agencies, thus prohibiting states from giving federal funds to private agencies. Id.

93. KATZ, supra note 68 , at 224. The chosen measures included federal grants-in-aid to the states, as well as work relief programs. The former included the Federal Emergency Relief Act, and the latter included the Civilian Conscrvation Corps, the Civilian Works Administration, and later, the Works Progress Administration. See id. at 226-29; PATTERSON, supra note 82, at 234.

94. KATZ, supra note 68, at 234. For instance, Roosevelt wamed Congress that "continued dependence upon relief induces a spiritual and moral disintegration fundamentally destructive to the national fibre. To dole out relief in this way is to administer a narcotic, a subtle destroyer of the human spirit." Id.

95. Pub. L. No. 74-271, 49 Stat. 620 (1935) (codified as amended at 42 U.S.C. $\$ \S 301-1397 f$ (1994)). The categorical nature of the Act derived from prior state and federal laws, and in keeping with history, it provided public assistance only to the "worthy" poor. See HANDLER, supra note 69, at 20. It also favored men over women. Mimi Abramovitz, Regulating tHe Lives of WoMen 235 (1996). 
administered by states and localities through grants-in-aid from the federal government. As a result of local administration, $A D C$ remained a small program until the 1960 s, and it primarily aided white widows, as had the forerunner state laws. ${ }^{96}$

Overall, the New Deal put in place the categorization of need that marks current welfare policy. It distinguished between social insurance (for the worthy masses, including the middle-classes) and public assistance (for the unworthy poor). ${ }^{97}$ It expanded the role of the federal government and forced the states to commit to poor relief and develop administrative structures for the distribution of that relief. ${ }^{98}$ It also "reinforced state and local variations in welfare benefits and froze into place the complex, multilayered, decentralized pattern that has distinguished relief and welfare in America since early in the nation's history.",99

After WWII, the country lost interest in poverty; the dominant ideology was one of mass prosperity. ${ }^{100}$ The prevalent belief among policymakers was that a strong economy would eliminate poverty. ${ }^{101}$ Nevertheless, the welfare rolls quietly increased, and by the mid-1950s most welfare funds went to $A D C$ recipients rather than to the aged. ${ }^{102}$ In response to this growth, the states implemented a variety of punitive policies designed to reduce the number of welfare recipients, including eligibility investigations of recipient households and "suitable home" requirements. ${ }^{103}$

During the 1960s, a growing awareness that the country's prosperity had not trickled down to all people replaced the optimism of the 1950s. Social and demographic shifts, including the flow of rural populations into the cities, the increasing number of persons on public assistance, and especially the civil rights movement, heightened public awareness of inequities in American society. ${ }^{104}$ In his bid for the presidency, Kennedy expressly made poverty and hunger a campaigu theme. ${ }^{105}$ Once elected, Kennedy, and then President Johnson, enacted significant welfare reform measures based on a "service strategy," which aimed to provide the poor with services to gain employment, such as job training and placement, rather than

\footnotetext{
96. ABRAMOVITZ, supra note 95, at 319.

97. KATZ, supra note 68 , at 242; PATtERSON, supra note 82 , at 76.

98. KATZ, supra note 68 , at 255.

99. Id. at 247.

100. PATterson, supra note 82 , at 78-79, 83; TrATtNer, supra note 67 , at 308 . Yet in the late 1950 s, poverty affected nearly 40 million people. $I d$. at 78 .

101. PATTERSON, supra note 82 , at 79,89 .

102. TRATTNER, supra note 67 , at 309 . Between the 1930 s and 1960 , the numbers of ADC recipients had grown from 701,000 to 3 million. PATTERSON, supra note 82 , at 86 . Still, only $1 \%$ of the gross national product was being spent on categorical or general assistance to the poor. Id.

103. ABRAMOVITZ, supra note 95, at 323-26; KATZ, supra note 68, at 261; PATTERson, supra note

104. KATZ, supra note 68 , at 260. James Patterson provides a detailed exploration of the "rediscovery" of poverty during this time period. See PATTERSON, supra note 82, at 99-114.

105. PATTERSON, supra note 82 , at $126-27$.
} 82 , at $87-88$. 
with money. ${ }^{106}$ The strategy, set forth in the Economic Opportunity Act of 1964 and administered by the Office of Economic Opportunity, was carried out by a vast network of private social service providers and community action agencies. Federal funds bypassed state and local governments and went directly to programs that federal law required be "administered with maximum feasible participation of the residents."107 Thus, "[t]he War on Poverty generated a nuniber of concepts and undertook a number of interventions that reflected, either explicitly or implicitly, a vote of no confidence in governmental services as then being delivered."108 Increased privatization, funded by federal dollars, was the result. Thus, both the federal government and private social services expanded greatly during this time period. ${ }^{109}$

The community action program was intensely controversial, as local officials, threatened by the loss of funds and control, vehemently attacked the program. ${ }^{110}$ Those attacks, coupled with budget cuts as a result of Vietnam War spending, eventually heralded the demise of the federal government's War on Poverty. ${ }^{111}$ Yet its legacy was far-reaching. It fostered grassroots social activism and created a generation of reformers, many of whon migrated into government service. ${ }^{112}$ It also spawned Head Start, legal services, and neighborhood service and health centers, and it mobilized the poor to agitate for their rights. ${ }^{113}$ It also started the interdependent relationship between government and private social welfare providers that continues to this day.

The expansion of federal government welfare spending that began in the early 1960s continued into the mid-1970s, despite President Nixon's anti-welfare rhetoric. ${ }^{114}$ All told, the time period from the early 1960 s to the

106. KATZ, supra note 68, at 263; Alice O'Connor, Neither Charity Nor Relief: The War on Poverty and the Effort to Redefine the Basis of Social Provision, in WrTH Us ALwAYs, supra note 91, at 191, 191-92.

107. KATZ, supra note 68 , at 267.

108. Arnold Gurin, Governmental Responsibility and Privatization: Examples from Four Social Services, in Privatization and the Welfare State 179, 182 (Sheila B. Kamerman \& Alfred J. Kahn eds., 1989).

109. See id. at 183 ("The 1960 s, thus, were a period of great expansion in the role of government, especially the federal government, but also a period of expansion in privatization of various kinds, both nonprofit and for-profit, fueled largely by government funds.").

110. Patterson, supra note 82, at 146-47.

111. See id. at 148; O'Connor, supra note 106, at 207. Nixon finally closed the OEO in 1974, transferring its remaining programs to other government departments. KATZ, supra note 68, at 268.

112. KATZ, supra note 68, at 263.

113. Patterson, supra note 82, at 126. As part of the backlash to the War on Poverty, Congress enacted two "work incentive" programs, in 1967 and 1971 respectively, designed to push AFDC recipients into the workplace. HANDLER, supra note 69, at 58; PATTERSON, supra note 82, at 175-76. Both programs failed. Id.

114. KATZ, supra note 68 , at 269-70. The poor benefitted from a variety of other legislative gains during Nixon's tenure, including increases in food stamp and Social Security spending and the federalization of supplemental security income, which set an income fioor for the less controversial 
mid-1970s saw three significant trends. First, there was a massive increase in government spending on social welfare programs. ${ }^{115}$ As noted earlier, much of this spending went to private voluntary agencies, thus creating a "mixed" welfare state that "marked a creation unique to the United States, reflecting a deep-seated American tradition of associative enterprise that combines self-reliance and private voluntarism with communitarianism and government activity." matically reduced the numbers of poor. ${ }^{117}$ Third, and despite the second trend, the number of AFDC recipients grew dramatically. ${ }^{118}$ Several intertwined reasons explain this growth in the number of AFDC recipients, including an increase in the number of eligible families that applied for aid as the welfare rights movement gathered steam; ${ }^{119}$ an increase in eligible applicants who were actually assisted by the states (particularly northern states, which paid higher benefits and which liberalized eligibility requirements); and demographic changes, such as population growth and rising divorce and illegitimacy rates. ${ }^{120}$

The next major shift in welfare policy occurred in the 1980s. President Reagan advocated the work ethic, blamed the poor for their condition, and accordingly, promised to slash social welfare spending. ${ }^{121}$ In a throwback to Hoover, Reagan believed that welfare should be provided by private volunteer organizations. ${ }^{22}$ While Congress defeated many of Reagan's more extreme proposals to eliminate social spending, significant cuts survived nonetheless, including cuts to food stamps, child nutrition, and unemployment insurance. ${ }^{123}$ In 1981, Reagan pushed legislation through Congress that cut back work incentives for those on AFDC and that

adult categories of public assistance: the aged, blind, and disabled. PATTERson, supra note 82, at 168, 197. The proposed floor was higher than AFDC payments in eight southern states. Id. at 193; see also TRATTNER, supra note 67 , at 348-51.

115. Expenditures rose at an annual rate of $7.2 \%$ for the years between 1965 and 1976, compared to $4.6 \%$ annually from 1950 to 1965 . Social welfare spending went from $7.7 \%$ of the gross national product in 1960 to $16 \%$ in 1974 , although the bulk of that money went for non-mcans-tested programs such as Social Security and Medicare. PATterson, supra note 82, at 164.

116. Donald T. Critchlow, Implementing Family Planning Policy: Philanthropic Foundations and the Modern Welfare State, in WrrH Us Always, supra note 91, at 211, 212.

117. KATz, supra note 68, at 278. According to flgures based on the official poverty line, "the number of poor Americans decreased from 39 million (22 percent of the population) in 1959, to 32 million (17 percent) in 1965, to 25 million (13 percent) in 1968, to 23 million (1 1 percent) in 1973." PATterson, supra note 82 , at 160.

118. PAtTerson, supra note 82, at 171 (increasing from " 3.1 million in 1960 to 4.3 million in 1965 to 6.1 million in 1969 to 10.8 million by 1974 ").

119. TRATTNER, supra note 67 , at 343-44.

120. ABRAMOVITZ, supra note 95, at 334-35; KATZ, supra note 68, at 275-76; PATTERSON, supra note 82 , at $178-84$.

121. PATterson, supra note 82, at 213; TRATTNER, supra note 67, at 370 .

122. KATZ, supra note 68 , at 289.

123. KATZ, supra note 68, at 296-97; PATTERSON, supra note 82, at 212. 
restricted AFDC eligibility. ${ }^{124}$ Reagan's cuts to social spending also devastated the very private programs he was counting on to alleviate poverty. ${ }^{125}$ Not surprisingly, the poverty rate began growing again, and by 1983 , the poverty rate was the highest it had been since the mid $1960 \mathrm{~s} .{ }^{126}$

Increasing poverty rates helped fuel an obsession with a perceived growing underclass. ${ }^{127}$ In 1984, Charles Murray, a conservative sociologist, fanned the flames by publishing an influential book called Losing Ground, in which he argued that welfare created dependency and prevented the poor from achieving self-sufficiency. ${ }^{128} \mathrm{He}$ proposed that all public welfare programs be eliminated, with the possible exception of uneinployment insurance. ${ }^{129}$ Soon, the states began experimenting with workfare (that is, work requirements tied to the receipt of welfare benefits); by 1987 , forty states had such programs. ${ }^{130}$ In 1988 , the workfare concept became part of federal law when Reagan signed the Family Support Act, which enacted the Job Opportunities and Basic Skills (JOBS) program. ${ }^{131}$ JOBS required single parents on welfare whose children were over three years old-or over one in some states - to work as a condition of receiving benefits, or, if they could not find a job, to enroll in education or job training courses. ${ }^{132}$ Like previous federal work programs, JOBS ultimately made little difference in the lives of the poor. The states, strapped for cash, failed to start or expand job training programs or to provide ample funds for child care or other

124. ABRAMovitz, supra note 95, at 355-56 (as a result of this legislation, between 1981 and $1983,400,000$ working welfare mothers lost their grant); KATZ, supra note 68, at 306.

125. See KATZ, supra note 68, at 296-97, 289; SALAMON, supra note 66, at 153-54, 166, 194-95.

126. TRATTNER, supra note 67 , at 368 (by 1983 , the poverty rate had risen to $15.3 \%$ of the population). At this time, the feminization of poverty continued. That is, two out of every three poor adults were women. Id. at 370; see also PATTERSON, supra note 82, at 219.

127. PATTERSON, supra note 82 , at 215-18.

128. Charles Murray, Losing Ground: American Social Policy, 1950-1980 (1984).

129. Id. at 227-33. "What Murray ignored was the fact that, between 1960 and 1972 , precisely the years when welfare programs really proliferated, poverty in America was cut in half-and the greatest growth in poverty came during the early 1980 s, when the Reagan administration curtailed and eliminated such programs." TratTNER, supra note 67, at 371 n.13. Murray's position has been skillfully critiqued by, among others, Christopher Jencks, The Safety Net, in RetHinking Sociai. Policy: RACE, POVERTY, AND THE UNDERCLASS 70, 70-91 (1992); Jeffrey Lehman \& Sheldon Danzinger, Reflections on Welfare Reform, 37 U. Mich. L. QuaNDrangle Notes 34, 37-38 (1994); Lucy A. Williams, The Ideology of Division: Behavior Modification Welfare Reform Proposal, 102 YALE L.J. 719 (1992); Sheldon Danzinger \& Peter Gottschalk, The Poverty of Losing Ground, Challenge, May/June 1985, at 32; Robert Greenstein, Losing Faith in 'Losing Ground,'New REPUBLIC, Mar. 25, 1985, at 12.

130. TrattNer, supra note 67 , at 375 .

131. 42 U.S.C. $\$ \$ 681-687$ (repealed 1996).

132. JOBS was based on the dubious assumptions, disproven by many scholars, "that most recipients have been on welfare for long periods of time (even generations), by choice; that they are able to get, and to hold, jobs, or would be able to do so after receiving some basic education or job training, that paid employment was the ticket out of poverty for women on welfare; and that they will enter the labor force only when required by law or threatened with starvation." TRATTNER, supra note 67 , at 377 . 
supportive services, ${ }^{133}$ and, as a result, only a small percentage of welfare clients actually enrolled in work programs. ${ }^{134}$

President Bush replicated Reagan's approach to poverty; Bush's domestic welfare agenda focused on advocating for a "thousand points of light," or volunteerism. ${ }^{135}$ Meanwhile, however, the poverty rate climbed and welfare applications soared. ${ }^{136}$ In response, in the late 1980s, states began to freeze or reduce AFDC benefits. ${ }^{137}$ They requested waivers from the federal government to experiment with behavior modification welfare programs such as learnfare (sanctions for families whose teenage children missed school), family caps (denial of additional benefits to mothers who gave birth to additional children while on AFDC), healthfare (reduced benefits for families that failed to get children immunized), and wedfare (bonuses to welfare mothers who married). ${ }^{138}$ The states thus bccame the laboratories and agents of changes that were eventually passed into federal law in the PRA.

After his election in 1992, President Clinton encouraged these state waivers. ${ }^{139} \mathrm{He}$ had campaigned upon a promise to "end welfare as we know it." In 1993, his administration granted a waiver to Wisconsin to develop a workfare program with a two-year lifetime limit on benefits. ${ }^{140}$ With the Republican takeover of Congress in 1994, and the resulting Contract With America, the pressure increased on Clinton to pass substantial welfare reform legislation. ${ }^{141}$ After vetoing two Republican versions of welfare reform, Clinton signed the PRA into law in $1996 .{ }^{142}$ As enacted, the PRA reflects many of the themes of colonial poor law, including an emphasis on local responsibility, restrictions on aid to "strangers," or out-of-state residents (subsequently struck down by the Supreme Court), ${ }^{143}$ and a "work or starve" mentality for the able bodied. ${ }^{144}$ At the same time, by encouraging states to use private entities as welfare providers, the PRA embodies

133. Id. at 381; AвRAMovitz, supra note 95, at 357-61; KATZ, supra note 68, at 301, 309; Patterson, supra note 82, at 231-32.

134. KaTz, supra note 68, at 301 .

135. TRATTNER, stpra note 67 , at $379,383$.

136. Id. at 380. Between 1989 and 1992 , the poverty rate rose sharply to $14.5 \%$ of the population, from $12.8 \%$. PATtERSON, supra note 82 , at 225 . AFDC rolls jumped by $25 \%$ in this time period. Id. at 229.

137. TRATTNER, supra note 67, at 380 .

138. KaTZ, supra note 68, at 310-11; PATrerson, supra note 82, at 239.

139. ABRAmovitz, supra note 95, at 362; PATTERSON, supra note 82, at 239; TRATTNER, supra note 67 , at 396.

140. PATTERSON, supra note 82, at 240.

141. AвRAMOVITZ, supra note 95, at 363; KaTZ, supra note 68, at 301.

142. For a complete history of the legislation, see Congressional Quarterly Almanac 6-3 to 6-24 (1996).

143. Saenz v. Roe, 526 U.S. 489 (1999) (holding that TANF residency requirements violated the Privileges and Immunities Clause).

144. TRATTNER, supra note 67, at 397. 
strands of the War on Poverty and its emphasis on community-oriented service delivery as well as the government's general trend toward privatization. Yet the PRA's privatization provision received scant notice in the legislative debates; it was overshadowed by the spotlight thrown on the Act's overtly punitive measures. ${ }^{145}$ This barely acknowledged addition to the law has the potential to alter the rights of millions of welfare recipients.

\section{Conclusion}

This brief history reveals that the poor have relied on both public and private provision of welfare since the founding of this country. Contrary to the claims of soine privatization proponents, there never was a mythic "golden age" during which private charity alone took care of the needs of the poor. Rather, government has always provided the majority of funding for poor relief. Left to their own devices, private entities would be unable to relieve poverty. At the same time, the government has always relied on private entities to carry out many of its social service objectives. So, calls for the government alone to carry the burden of poor relief are equally unrealistic. At bottom, it appears that publicly funded, privately provided social service delivery is here to stay. ${ }^{146}$ However, the entry of for-profit entities and the devolution of eligibility and sanctioning functions to private entities raises new and troubling questions.

\section{B. New Directions in Welfare Privatization}

The PRA has brought for-profit entities into the social service fold on a scale above and beyond their traditional involvement as contractors for information and data systems. ${ }^{147}$ Unlike government and most nonprofit agencies, these for-profit providers are trying to make money, which may affect their accountability and the quality of service they provide to

145. The only significant debate about Section 104 revolved around allowing religious organizations to provide welfare services. PRA allows states to contract with religious organizations to provide welfare services. Pub. L. No. 104-193, \$ 104(b), 110 Stat. 2105, 2162 (1996) (codified at 42 U.S.C. $\$ 604 a$ ). This obviously raises issues under the Establishment Clause. Thus, states cannot discriminate against religious organizations that apply to be contractors. Id. $\$ 104$ (c). At the same time, beneficiaries who object to the religious character of a provider organization are entitled to assistance from an altemative provider within a reasonable period of time after objecting. Id. $\S 102(\mathrm{e})(1)$. Further, religious organizations cannot discriminate against individuals on the basis of religion. $I d . \$ 102(\mathrm{~g})$. Reliance on faith-based organizations to supply social welfare is controversial, and it is not clear how effective they would be in an expanded role. See Jacab S. Hacker, Faith Healers, New RePubLic, June 28,1999 , at 16. For some of the legislative debates on the privatization provision see H.R. REP. No. 104-651, at 1374-75 (1996), reprinted in 1996 U.S.C.C.A.N. 2183, 2433-34; 142 CoNG. REC. S8493 (daily ed. July 3, 1996); 141 CoNG. REc. S13481 (daily ed. Sept. 13, 1995).

146. Privatization may be appealing to governments who find intemal reform too politically costly. See Jonas Prager, Contracting-Out: Theory and Policy, 25 N.Y.U. J. INT'L L. \& PoL. 73, 103 (1992).

147. See Demetra Smith Nightingale \& Nancy Pindus, Urban Inst., Privatization of Public Social Services: A Background Paper 5 (1997). 
beneficiaries. In many contracting schemes, which pay a set fee to the contractor, the more money the provider saves, the more money the provider gets to keep. ${ }^{148}$ This raises incentives for profit-seeking organizations to cut staffs and to implement other cost-savings measures that can impact the quality of service provided. In other contracting schemes, where fees are paid based on services provided, there are incentives to help only those persons most easily placed in jobs. Thus, profit-making entities often have incentives inconsistent with the needs of welfare recipients. These changes heighten the importance of ascertaining whether welfare recipients have any enforceable rights against welfare providers. ${ }^{149}$

Several states have jumped on the privatization bandwagon, and others are beginning to move in that direction. ${ }^{150}$ Wisconsin pioneered the privatization of welfare services, privatizing pursuant to a waiver from HHS even before the 1996 welfare reform statute. As of January 1998, private companies handled the entire welfare caseload in Milwaukee, where seventy percent of the state's welfare caseload resides. ${ }^{151}$ Arizona is another state leader in welfare privatization. In early 1999, it started a pilot program called ARIZONA WORKS in a portion of Maricopa County, which covers metropolitan Phoenix. ${ }^{152}$ This privatized district is being run by Maximus, Inc., a for-profit corporation, and is expected to take in about thirteen percent of the state's $\$ 160$ million welfare budget. ${ }^{153}$ Although Arizona has long contracted with private service providers for discrete services, the new pilot program was intensely controversial, largely because of the influx of for-profit providers and their authority to conduct eligibility functions. It thus faced vocal opposition from welfare advocates and public enuployee unions. ${ }^{154}$ Arizona's plan envisions expansion of privatization; it calls for additional privatization projects and for study and consideration of further privatization initiatives. ${ }^{155}$ Other jurisdictions that

148. See, e.g., DoDEnhofF, supra note 61 , at 4.

149. For one creative strategy, see Cheryl L. Wade, For-Profit Corporations That Perform Public Functions: Politics, Profit, and Poverty, 51 Rutgers L. Rev. 323, 327, 330 (1999). She explains that the shareholder primacy paradigm of private corporations leaves out any concern for the beneficiaries of the privatized social services programs. Accordingly, sbe argues for increased accountability of forprofit social service providers through a revised notion of corporate law that would require that directors and officers of the corporations fulfill fiduciary obligations to the constituents of these programs (whom she calls Corporate Dependents) rather than solely to shareholders.

150. In 1998, USA Today reported that more than thirty states had turned over parts of their welfare systems-ranging from job placement to eligibility determinations-to the private sector. Richard Wolf, Public Aid Going Private in Many States, USA TodAy, Aug. 3, 1998, at 3A. A summary of privatization initiatives on a state-by-state basis can be found at http://www.welfareinfo.org (last visited Nov. 1, 2000).

151. See DODENHOFF, supra note 61, at 3, 13-17.

152. See John Stuart Hall \& Gerald J. Kubiak, Arizona's Welfare Reform Experience, Rockefeller Reports, at http://rockinst.org.reports/rr13.html (Nov. 2, 1999).

153. See id.

154. Id.

155. See id.; Ar1z. Rev. Stat. ANN. $§ 46-342$ (West 2000). 
also have significant welfare privatization initiatives underway include Texas; ${ }^{156}$ Florida; ${ }^{157}$ and Orange, San Diego, and Los Angeles Counties in California. ${ }^{158}$ Notably, the inost extensive privatization programs are occurring in urban areas, such as Milwaukee and Phoenix. This coincides with the deinographic trend that inost of America's welfare families hive in urban areas. ${ }^{159}$ Thus, privatization is poised to affect a significant number of welfare recipients.

Currently, the big for-profit players in welfare privatization are Lockheed Martin and Maximus. Maximus bills itself as the "nation's largest private sector provider of job developinent and placement services to the disadvantaged."160 Although the company was formed in 1975, its business increased dramatically in the wake of welfare reform and it went public in $1997 .^{161}$ If it were a state, Maximus would have the country's 29th largest social services caseload in the country, ${ }^{162}$ and it holds a thirty percent share in the growing health and human services market. ${ }^{163}$ Unlike Maximus, which has always focused on the human services field, Lockheed Martin's business has long centered on defense contracting. However, with declining defense spending, Lockheed has focused on developing new business areas, and now welfare reform services represent one of its two fastestgrowing business lines. ${ }^{164}$ The company states that in the last four years it

156. Merrill Goozner, Welfare's Gold Rush: Private Sector Mining Hard for Reform Effort's Contracts, Chicago Tribune, June 29, 1997, at 1C; Welfare Information Network, Privatization, available at http://www.welfareinfo.org/privitization.htm (last visited February 21, 2001).

157. See Deborah Hardin Wagner, Welfare's Forgotten Families: Training Not Included, ST. Perersburg Tmes, Nov. 7, 1999, at ID; Safety Net of Florida, WAGES Coalition Profiles, available at http:/wnw.flimpact.org/wagesprofil.html (last visited Nov. 22, 2000) (describing in detail on a regional basis the public-private coalitions that are charged with setting up contracting with private providers and developing jobs).

158. See Karen Kucher, Lawsuit Targets Welfare Contracts; Group Claims Profit Motivated Awards, San Drego UnIon-Trib., Aug. 3, 1999, at Bl; Nicholas Riccardi, County Nears Private Bids on Welfare Reform, L.A. TmEs, Feb. 8, 2000, at B1; Nicholas Riccardi, Supervisors Privatize JobTraining Services, L.A. TmEs, July 12, 2000, at B3; Janet Wilson, County Planning to Contract Out Bulk of Welfare Reform Efforts, L.A. TMES, Mar. 12, 1998, at B1.

159. ALLEN \& KIRBY, supra note 64, at 1 . The concentration of poverty in urban areas poses grave challenges for policymakers who must contend with a population served by poor schools, weak job information networks, and scarce employment opportunities. Id. at 4. These urban areas contain a greater share of hard-to-serve welfare families, i.e., those facing multiple barriers to work. Id.

160. This sales pitch is available at Maximus, Inc., Welfare to Work, http://www.1naxinc.com/broch4.html.

161. Frederic J. Frommer, Strategies; Maximus Pulling in the Outsourcing Jobs, WASH. Posr, Sept. 20, 1999, at F13.

162. Lorraine Woellert, Maximus, Inc.: Welfare Privatizer, Bus. WeEk, May 31, 1999, at 96.

163. Id.

164. Jonathan Walters, The Welfare Bonanza, GoverNING, Jan. 2000, at 34; see also Greg Schneider, Defense Industry Faces Consolidation, Transition; Mergers Also Likely to Continue, BaLr. SuN, Jan. 18, 1998, at 13K. However, according to Lockheed's Website, sales to the Department of Defense still constitute $53 \%$ of its profits. See Lockheed Martin, About Us: At a Glance, at http://www.lockheedmartin.com/about/ataglance.htm (last visited Nov. 22, 2000). 
has gone from zero to forty contracts in twenty-nine locations. ${ }^{165}$ Lockheed aggressively recruits former government welfare officials to bolster this growing line of work. ${ }^{166}$ Along with these two corporate behemoths, many smaller nonprofit and for-profit organizations play a role in welfare reform on a local basis.

\section{The Broader Privatization Movement}

Beyond the welfare context, privatization is proliferating in spheres traditionally run by government. Privatization, "a fuzzy concept that evokes sharp political reactions," 167 generally entails the transfer of governmental functions to the private sector. Privatization initiatives range from contracting, vouchers, subsidies, franchises, and tax credits, to more extreme forms such as load-shedding, in which the government eliminates its role in certain areas by selling its assets to the private sector or withdrawing from providing a service altogether. ${ }^{168}$ The dominant form of privatization in this country, and the form endorsed by TANF, is contracting out, $\mathrm{m}$ which government funds services but contracts for their iniplementation with the private sector. ${ }^{169}$ In the United States, "more than half of all government spending on goods and services is publicly financed but privately produced." 170 The history of welfare in America, discussed above, reveals that TANF's endorsement of privatization is the latest, and most far-reaching, extension of government's increasing reliance on private entities to carry out its welfare objectives. It is also traceable to the mcreasmg momentum of the broader privatization movement that took root during the Reagan Administration in the 1980s, as prominent American conservatives became influenced by Britain's Thatcher government, which had privatized

165. See Lockhced Martin, About Us: At a Glance, at http://www.lockheedmartin.com/about/ataglance.htm (last visited Nov. 22, 2000).

166. See, e.g., Kery Murakami, Corporate Giants Eye the Welfare Rolls, SeatTle Times, Jan. 6, 1997 , at B1.

167. Paul Start, The Meaning of Privatization, in Prvatization and the Welfare State, supra note 108 , at 15 .

168. See id. at 24; Adrian Moore \& Wade Hudson, The Evolution of Privatization Practices and Strategies, in Local Government InNovation 17, 18-20 (Robin A. Johnson \& Norman Walzer eds., 2000); Paul Seidenstat, Theory and Practice of Contracting Out in the United States, in ConTracting Out Government Services 3, 4-8 (Paul Seidenstat ed., 1999). In other parts of the world, privatization is most often associated with selling off government assets. See JOHN D. DONAHUE, THE Privatization Decision 6 (1989). For instance, in the 1980s, Britain sold off British Gas, British Telcom, Jaguar, British Airways, the Sealink Ferry Service, all or part of its stakes in British Sugar, British Aerospace, British Petroleum, and British Steel, among other things. Id. By contrast, the American government has simply never owned as many enterprises. Thus, "most of the activities that tend to work badly in the public seetor, as both industrialized and third-world countries learned to their sorrow in the post-war decades, America had kept private in the first place." Id. at 7.

169. Joel Handler, Down From Bureaucracy: The Ambigumy of Privatization and EMPOWERMENT 78 (1996); Seidenstat, supra note 168, at 8, 8-10 (“[P]ractically all privatization in education, health, mental health, soeial services, and transportation rehes . . . on contracting out.").

170. HANDLER, supra note 169 , at 7 . 
and sold off major government programs throughout the $1980 \mathrm{~s}^{171}$

Soon, local governments increased contracting for municipal services from trash collection to highway maintenance, and, as a result, privatization became less of a novelty and more of a standard option for governance. Moreover, privatization was securely placed on the public agenda and became part of a conservative intellectual and philosophical movement that continues to this day and that underlies the TANF privatization option. ${ }^{172}$ Its appeal has become bipartisan, as exemplified by President Clinton's initiative for Remventing Government, yet another attempt to downsize the federal government and to make up the shortfall through private contracting. ${ }^{173}$ Currently, various privatization initiatives are dominating public discourse in other social service areas including charter schools, child welfare, child support enforcement, and Social Security. ${ }^{174}$

III

\section{Privatization AND Accountability}

Government plans to privatize typically engender heated and acrimonious debate, and the privatization of welfare is no exception. Privatization raises accountability issues for all whom it affects: government employees, program beneficiaries, and the tax-paying public. Each of these groups has conflicting goals and desires, and vast disagreements over the costs and benefits of privatization can exist within each group. Accordingly, Part A traces the arguments for and against privatization as a means of understanding the values at stake. Part B then examines what the empirical evidence reveals about social service privatization. The purpose of this analysis is not to take a stand in the privatization debate. Rather, the empirical analysis is important to better understand how privatization is likely to impact the rights of beneficiaries. In brief, due to a lack of vigorous competition, privatization in the social services field rarely dehvers on the supposed benefits of privatization. At the same time, the very imstitutional structure that results from privatization appears to decrease accountability

171. See DONAHUE, supra note 168, at 4-5; Norman Walzer \& Robin A. Johnson, Introduction and Overview, in Local Government InNOvation, supra note 168 at 1,5 . In fact, the word "privatization" only began to appear in dictionaries around this time. See Seidenstat, supra note 168, at 4.

172. Although much of President Reagan's rhetoric was never transformed into action, "the hetoric itself changed the way in which the public viewed government. People believed nore than ever that not only was government wasteful and interfering but government itself was the problem." Ruth Hoogland Dehoog \& Lana Stein, Municipal Contracting in the 1980s: Tinkering or Reinventing Government, in Contracting Out GOVERNMENT SERVICES, supra note 168, at 26. Emblematic of the conservative privatization movement are the books by Emanuel Savas including, PrivatizING THE Public Sector: How to Shrink Government (1982).

173. Dehoog \& Stein, supra note 172, at 27.

174. For a discussion of privatization in the context of foster care, see Susan Vivian Mangold, Protection, Privatization, and Profit in the Foster Care System, 60 Oнг ST. L. J. 1295 (1999). 
to program beneficiaries. This, in turn, increases the importance of legal remedies as a bulwark against the unfettered discretion of private entities, a subject dealt with in the remainder of this Article.

\section{A. The Arguments for and Against Privatization}

Privatization advocates, relying largely on market force economic theories, contend that private companies can deliver services with greater efficiency and innovation than government at a lower cost. Cost savings are said to derive from a variety of sources:

competition among firms that may create pressure for efficiency not present in a monopoly municipal department; a relative freedom from "red tape" and other procedural constraints; and the ability of private firms to hire, fire, compensate, and therefore motivate and utilize workers with greater fiexibility than can government departments constrained both by civil service rules and strong unions. ${ }^{75}$

Yet another strand of the privatization movement sees privatization as a democratizing force that returns power from the government to local cominunities and their mediating institutions, such as churches, neighborhoods, and voluntary organizations, which are better situated to address a community's needs. ${ }^{176}$ This argument gains support not only from conservatives, but also from some liberals who advocate a communitarian, grassroots vision of social service delivery. ${ }^{177}$ Thus, privatization of welfare converges "the free market ideology of the right and the citizen participation/empowerment objectives of the left." 178

Opponents of privatization generally share the contrary ideological view that government should play a strong social role in addressing the needs of the unfortunate and that government can better provide services in a uniform, nondiscriminatory manner. They argue that privatization lessens governmental accountability and thus leaves private entities susceptible to fraud, corruption, and conflicts of interest. ${ }^{179}$ Along these lines, they contend that a democratic government should not delegate functions that affect

175. Marc Bendick, Jr., Privatizating the Delivery of Social Welfare Services: An Idea to be Taken Seriously, in Privatization and the Welfare State, supra note 108, at 97, 107. The Reason Foundation has been especially prominent in advocating for privatization and providing technical assistance to jurisdictions considering privatization. See Reason Public Policy INST., Privatization 1999: The 13Th ANNuAl Report ON PRivatization (1999).

176. Starr, supra note 167 , at 26 .

177. This view is associated with Peter Berger and Richard Neuhaus and is well-summarized in Starr, supra note 167, at 34; see also HANDLER, supra note 169, at 68.

178. Neil Gilbert, Welfare Reform: Implications and Alternatives, 7 Hastings Women's L.J. 323, 328 (1996).

179. See Steven Rathgeb Smith \& Michael Lipsky, Nonprofits for Hire: The Welfare State in the Age of Contracting 98-99 (1993). 
disenfranchised and marginalized persons. ${ }^{180}$ Especially in the welfare context, opponents fear that private entities have mcentives to reduce the quahity of services and to "cream" off those most likely to succeed in a program while denying services to those with the most intractable problems. These concerns arguably are heightened for programs in which payinent to the private provider is based on a fixed cost per client served.

Critics also challenge the supposed benefits and underlying assumptions of privatization. As for cost, critics contend that both the expense of soliciting and monitoring contracts and the cost of the contractor's profit actually can make privatization more expensive than publicly provided services. ${ }^{181}$ As for efficiency, critics point to large private entities whose bureaucratic structures often mirror those of large governmental agencies. They downplay the effects of marketplace competition, arguing that once contracts are awarded, they are often renewed automatically and become self-perpetuating, thus minimizing innovation and creating an intractable private bureaucracy. Moreover, they question whether the market metaphor is appropriate in the context of social services because a third party (the government) is purchasing the service for the consumer (the beneficiary). ${ }^{182}$ Where the consumers are needy and vulnerable, it is unlikely that they can bargain for quality services. As for the supposed democratizing effects of privatization, opponents claim that privatization reduces citizen participation in government and can cause nonprofit agencies to become co-opted by their governmental overseers. ${ }^{183}$ Another frequently raised argument against privatization is the disruption in services that occurs when a company declares bankruptcy or goes out of business. ${ }^{184}$ Finally, some opponents fear the loss of good public sector jobs to lower-paying private jobs with fewer benefits, and accordingly, public employee unions are often the most vocal privatization critics. ${ }^{185}$ Indeed, much of the cost savings of privatization derives from the ability to pay lower wages to nonunionized and/or nongovernment employees.

1S0. See Sheila B. Kamerman \& Alfred J. Kahn, Continuing the Discussion and Taking a Stand, in Privatization and the Welfare State, supra note 108, at 261, 264.

181. See Terry Peters, Public Services and the Private Sector, in Privatization: The Provision of Public Services by the Private Sector 53, $58-59$ (Roger L. Kemp ed., 1991); Hatry, supra note 168 , at 25 ; Gurin, supra note 108 , at $200-01$.

182. See Gilbert, supra note 178 , at 328-29.

183. See, e.g., HANDLER, supra note 169 , at 85 .

184. See Peters, supra note 181 , at 58-59.

185. See, e.g., Nicholas Riccardi, County Nears Private Bids on Welfare Reform, L.A. Times, Feb. 8,2000 , at $\mathrm{Bl}$ (noting that the union representing welfare office employees has objected to Los Angeles County's move toward welfare privatization). This is a concern even where the govemment contracts with nonprofit groups. "Ironically, efforts to revitalize civil society through support of geographicallybased mediating institutions are being promoted at the cost of functionally-based communities of organized labor, which also constitute powerful mediating institutions." Gilbert, supra note 178, at 331. 


\section{B. The Empirical Evidence: The Necessity of Competition}

Clearly, much of the debate over privatization is political and centers . on opposing views of government's role in the modern welfare state. ${ }^{186}$ There is little empirical evidence to test these competing political views, but that which exists provides some valuable lessons for the welfare realm. In a wide-ranging examination of empirical studies across many types of privatized services, John Donahue found that privatization can offer increased efficiency without a corresponding loss in accountability only when certain conditions are met. ${ }^{187}$ After assessing privatization initiatives in garbage collection, military support services, office cleaning, firefighting services, transportation, and utilities, he concluded that the single most important factor for producing efficiency is competition. ${ }^{188}$ Thus, government agencies competing for contracts against private entities can maximize efficiency in a competitive market, while private entities can be as wasteful as the most inefficient government bureaucracy in a noncompetitive market. The "fundamental distinction ... is between competitive, output-based relationships and noncompetitive, input-based relationships rather than between profit-seekers and civil servants per se."189 The necessity of competition makes strong intuitive sense; indeed, the entire notion of privatization hinges on the benefits created by market forces.

According to Donahue, competition is fostered where tasks can be specified in advance and performance evaluated after the fact, where disappointing contractors can be replaced or penalized, and where government cares more about ends than means. ${ }^{190}$ Such circumstances present the strongest case for turning to profit-seekers rather than civil servants. He found that privatization worked well for certain discrete municipal services such as asphalt laying and janitorial services, but was less effective where complex social welfare initiatives were involved. ${ }^{191}$ In the latter programs, it is far more difficult to craft meaningful standards for evaluation, and it can be misleading to look solely at output as a measurement of value. ${ }^{192}$

186. However, it should be noted that when state and local governments decide to privatize, their decisions are made less for ideological reasons than for practical ones, i.e., for budgetary reasons or a desire to improve efficiency. See DeHoog \& Stein, supra note 172, at 32.

187. DONAHUE, supra note 168 , at 217-18.

188. Id. at 80; see also Prager, supra note 146, at 107.

189. DoNAHUE, supra note 168 , at $97-98$.

190. Id. at 79-80, 97-98.

191. DonaHUE, supra note 168 , at 217 . Other scholars have found similar results. For instance, Marc Bendick, Jr. reviewed several studies and found that private contractors work well for straightforward or specialized services such as refuse collection, processing payments, and data processing. However, where the project involves "more complex, undefinable, long-range, and 'subjective' services characteristic of the social welfare field, the record of successful experience rapidly thins." Bendick, supra note 175 , at 107.

192. As a cautionary tale, Donahue points to the Job Partnership Training Program (JPTP), which was enacted in 1982 (and which has been subsequently extinguished) with the goal of increasing job opportunities for low-income persons by giving the private sector responsibility for designing and 
This analysis raises serious questions for welfare privatization. As Donahue explains, competition can be hard to arrange or maintain for at least three reasons: (1) entrenchment, (2) difficulties in defining tasks and measuring performance, and (3) corruption. Welfare privatization implicates all of these threats to competition.

\section{Entrenchment}

Private contractors often get entrenched as they gain specific expertise and develop close relationships with government officials. ${ }^{193}$ This entrenchment is heightened where social services are involved because of "the lack of a large number of social service providers with sufficiently skilled labor, the high cost of entry into the social services field, and the need for continuity of care." 194 In the opening rounds of welfare privatization, there has been intense competition in the bidding for welfare contracts, but it has been concentrated between only a few large for-profit entities such as Lockheed Martin and Maximus. ${ }^{195}$ Moreover, once contracts are granted, history demonstrates that even this limited competition is likely to dissipate. In addition, these companies do not provide coinununity-oriented perspective and roots that are a supposed benefit of privatization. To the contrary, these large private entities are powerful lobbying forces, wielding inordinate influence over social welfare policy for corporate gain. ${ }^{196}$

running job training programs for disadvantaged persons. DonAHUE, supra note 168, at 179-211. Eligibility criteria were loosely defined to include the bottom one-fifth of the national income distribution, and local programs were vaguely directed to serve those who could benefit from training opportunities. Id. at 183. JPTP focused on output based measures of performance, namely, job placement. As a result, because the private trainers could select participants from a large and ill-defined eligible population, they creamed off those persons most likely to succeed and iguored the more diffieult persons. Id. at 199 . This, in turn, meant that JPTP was unlikely to create value; that is, it was unlikely to make "much difference for the employment, earnings, and productive capacity of American workers." Id. at 211.

193. DonaHuE, supra note 168 , at 78 . The phenomenon has been repeatedly documented in the human services field. HANDLER, supra note 169, at 88-90 (summarizing findings). Handler points to one study of the Massachusetts Department of Mental Health's contracting process that fonnd a lack of competition in bidding, largely because the '"goal of maintaining continuity of care,' economies of scale, and the difficulties associated with evaluating providers without 'track record' ... led to an increasing concentration of contracts with large organizations." Id. at 89. Handler concludes that in time "private suppliers, whether profit or nonprofit, come to resemble public monopolies." Id. at 217.

194. U.S. General Accounting Office, Social Service Privatization: Expansion Poses Challenges in Ensuring Accountabilrty for Program Results 12 (1997).

195. The immense value of these contracts has resulted in litigation between bidders. See Bruce Rubenstein, Privatization Wave Sparks Battle Over Virginia Contract, CorP. Legal Times, Mar. 1999, at 33 .

196. See Richard W. Roper, A Shifting Landscape: Contracting for Welfare Services in New Jersey, Rockefeller Reports, at http://rockinst.org/reports/rr10.html (Dec. 23, 1998). In Florida, private child welfare contractors lobbied the legislature to create a special immunity from litigation for themselves as a condition of agreeing to enter contracts with the state. Elizabeth Bettendorf, Comnunities Prepare to Manage Foster Care, TAMPA TRIB., Mar. 2, 1999, at 1; Limit the Risk for 
The presence of these behemoths is also likely to discourage smaller nonprofit providers from bidding for contracts, further reducing competition. ${ }^{197}$ This result is inconsistent with privatization's goal of returning control over welfare policies to communities. While smaller organizations, including nonprofits, still play a role in TANF, they are more likely to provide discrete services rather than to run entire welfare programs. Thus, they are playing essentially the same role they played before TANF. Yet as between for-profit and nonprofit providers, "[r]esearch indicates that nonprofit service deliverers have a distinctly better record than for-profit firms in providing services in the interest of clients beyond what is precisely specifiable in contracts." 198

\section{Difficulties in Defining Tasks and Measuring Performance}

Difficulties in defining tasks in advance and measuring performance can hinder competition by making it impossible to compare competitors. It is particularly hard in the area of welfare contracting to specify the desired tasks in advance. Putting people to work requires a complex assessment of the applicant's skills and family situation combined with available support services, such as child care and transportation, as well as opportunities in the local job market. These assessments, "because they involve direct contact with clients, . . . are at least partially unpredictable, largely unobservable and difficult to evaluate."199

Further, government officials have bemoaned the difficulty of "writing clear contracts with specific goals against which contractors can be held accountable." ${ }^{200}$ At the same time, under the PRA, performance is evaluated on outcomes, such as number of TANF recipients placed into jobs, rather than on process. Such performance-based contracting often pushes private entities to resort to "creaming" off those candidates most likely to succeed or "churning" off low-skilled candidates by making the

Child Services, St. Petersburg Times, Mar. 25, 1999, at 22A; John D. McKinnon, Question of Liability Limit Clouds Future of Privatized Child Welfare, WALL ST. J., Mar. 17, 1999, at F1.

197. For instance, in New York, where over $\$ 500$ million in welfare-to-work contracts were at stake, huge contracts with Maximus pushed out smaller job training and placement programs. Nina Bernstein, New Problems with Welfare-to-Work, N.Y. Times, Apr. 14, 2000, at B6. Maximus contracts were subsequently cancelled due to corruption in the bidding process. See infra notes 206-209 and accompanying text.

A study of welfare privatization in New Jersey likewise found that larger entities are pushing out smaller ones in part due to the data-rich accountability that accompanies performance based contracting; the smaller entities lack the experience and capacity to collect and report such complicated data. See Roper, supra note 196, at 10-11.

198. Bendick, supra note 175, at 113. However, as between nonprofit and government delivery of services, the evidence is scarce. Id. at 114 . Some studies have found that program quality does not differ much between the two types of provision, but that nonprofits may be able to implement programs more rapidly and may be able to reach clients more easily than government agencies. Id. at 114-15.

199. Meyers, supra note 63.

200. U.S. General Accounting Office, supra note 194, at 14. 
process so difficult to navigate that applicants give up. ${ }^{201}$ Such tactics may result in a cheery bottomline, such as low numbers of TANF recipients, but it will be one that does not serve the claimed purpose of the program to reduce welfare dependency.$^{202}$ It also gives no insights into the quality of the service provided. ${ }^{203}$

\section{Corruption}

Corruption or incompetence among government officials and/or private contractors may obliterate competition even where it is otherwise feasible. ${ }^{204}$ While there is little empirical evidence about welfare contracting under TANF, widespread anecdotal evidence of corruption exists in almost every jurisdiction that has experimented with privatization. For instance, Wisconsin is auditing Maximus Inc. for incorrectly billing the state for work and trips taken in pursuit of contracts in other jurisdictions. ${ }^{205}$ In New York, where $\$ 500$ million in welfare contracts is at stake, a State Supreme Court judge deemed the bidding process on welfare-to-work contracts to be corrupt and set aside more than \$I00 million in contracts awarded to Maximus Inc. ${ }^{206}$ The judge concluded that the city did not use a competitive bidding process in awarding the contracts and that extensive meetings between city officials and Maximus executives prior to the formal contracting process gave the company an unfair advantage. ${ }^{207}$ Subsequently,

201. It appears these phenomena already occur. See Sheryll D. Cashin, Federalism, Welfare Reform and the Minority Poor: Accounting for the Tyranny of State Majorities, 99 Colum. L. Rev. $552,565,602-08$ (1999) (describing "stringent work requirements and sanctions" that are resulting in high error rates and unexplained caseload declines unrelated to increased employment). In an article setting forth various criteria for governments to consider in weighing privatization, John O'Looney states, "Only outsource services for which providers can be held strictly accountable for both delivery and equitable provision. Services in which 'creaming' or 'cherry picking' of clients or tasks takes place should be avoided as this leads to mequality." John A. O'Looney, Selecting Services for Outsourcing, in Local Government InNOVATION, supra note 168 at 60,62 .

202. See supra note 192, describing the JPTP. This type of creaming was documented in a report of Pennsylvania's welfare privatization program, called Community Solutions, in which private contractors provide a broad range of pre-and post-employment services to TANF recipients referred by state social welfare offices. Diane Paulsell \& Robert G. WoOd, Mathematica Policy Research, Inc., The Commiunity Solutions INIMATIVE: EARLY IMPLEMENTATION EXPERIENCES (1999) (on file with author). The program uses performance-based contracts in which payments are tied to the achievement of specific performance goals with individual clients. Id. at 24 . The report found evidence that this sort of contracting prompted some contractors to implement selective admissions policies. Id. at 25 . In addition, monitoring performance goals has proven extremely complicated, increasing costs and delaying payments to contractors. Id. at 24-25.

203. U.S. GeNERAL AcCounting OFFICE, supra note 194, at 15.

204. DonaHuE, supra note 168 , at 78 .

205. Christopher Drew, Wisconsin to Audit Welfare Contractor, N.Y. TimEs, May 11, 2000, at B14. The state is also investigating a not-for-profit organization for similar violations. See Steve Schultze, State Gets Tab for W-2 Firm's Outside Work, Mrlwaukee J. Sent., Aug. 28, 2000, at 1 A.

206. Christopher Drew \& Eric Lipton, 2 With Ties to Chief of Welfare Got Jobs with Major Contractor, N.Y. Times, Apr. 21, 2000, at Al.

207. A Judicial Rebuke for the City, N.Y. TIMEs, Apr. 17, 2000, at A18; Eric Lipton, Judge's Ruling Bars Contracts in Welfare Plan, N.Y. TIMEs, Apr. 14, 2000, at A1. 
Maximus acknowledged that it hired the father-in-law and family friend of the city's welfare commissioner as it was trying to secure the contracts. ${ }^{208}$ Both the United States Attorney and the district attorney are investigating the bidding process. ${ }^{209}$

The potential lack of competition in welfare contracting, coupled with the difficulty in articulating performance objectives and means, raises serious questions whether privatization is appropriate in the welfare or social services context. Given the reality of the growing privatization of social services, ${ }^{210}$ legal avenues for enforcing accountability become more important. Yet the legal dimensions of privatization are usually ignored in the raging and highly politicized debates over privatization. ${ }^{211}$

\section{Legal Aspects of Privatization}

The legal implications of privatization can impact the assessment of benefits and costs of privatizing. For instance, as noted above, it is often assumed that government can save money by privatizing. One aspect of cost savings is said to come from government's ability to shift risk and liability to the private sector. Legally, this may or may not be true depending on the type of liability involved, the actors implicated, relevant statutes, and the terms of the contract, if any, between the government and the private provider. Furthermore, the ability of government or private agencies to avoid liability can impact the accountability of these institutions to taxpayers and beneficiaries. Cost savings can also be negated when opponents, particularly public employee unions, as well as public administrators or taxpayers, file lawsuits to prevent the privatization. ${ }^{212}$

In addition, privatization raises a host of other legal issues ranging from government contracting strategies ${ }^{213}$ to legal barriers to privatization $^{214}$ to freedom of information protections. ${ }^{215}$ Finally, there may be

208. Mayor Defends Welfare Hirings, N.Y. Times, Apr. 23, 2000, § 1, at 30.

209. See Eric Lipton \& Christopher Drew, Company Says City Forsook Welfare Deal, N.Y. TIMES, May 11, 2000, at B1; Eric Lipton \& Christopher Drew, A Contractor for Workfare Faces Inquiry, N.Y. Times, Apr. 22, 2000, at B1.

210. U.S. General Accounting OfFice, supra note 194, at 9-10.

211. The exception is in the context of the privatization of prisons. See Ira P. Robbins, The Legal Dimensions of Private Incarceration, 38 AM. U. L. REv. 531 (1989).

212. See Nicholas Morgan, Legal Barriers to Local Privatization, in ConTracting OuT Government Services, supra note 168, at 194; Caitlin Rother, Judge Orders Privatized Welfare Contracts Ended, SAN Dieco Union-TRIB., Sept. 9, 2000, at B-5 (reporting how judge terminated \$17 million worth of annual welfare-to-work contracts in lawsuit brought by public employees union).

213. State government officials who participated in a study by the U.S. General Accounting Office study stated that the most important and most difficult task in privatizing is writing specific work statements for privatization contracts. U.S. General Accounting Office, Privatization: Lessons LEARNED BY STATE AND Local GovernMENTS 17 (1997); see also JoHn A. O'LoONEy, Outsourcing State and Local Government Services 121-55 (1998); Ronald A. Cass, Privatization: Politics, Law, and Theory, 71 MARQ. L. REv. 449, 518-22 (1988).

214. Sec Morgan, supra note 212 , at 194-210. 
constitutional limitations on the extent of delegation of welfare programs from the government to the private sector. ${ }^{216}$ While this Article focuses primarily on how privatization affects legal accountability for process violations in the context of welfare, any policy discussion or assessment of welfare privatization needs to take into account all of these legal dimensions.

\section{IV}

\section{Enforcing Due Process in a Privatized Welfare System}

Under AFDC, using the legal system to enforce accountability from welfare providers was straightforward. AFDC benefits were entitlements to which constitutional protections attached, ${ }^{217}$ and the persons delivering and administering the benefits were government employees. Thus, accountability was enforced through constitutional and statutory litigation, often resulting in wide-ranging and comprehensive structural remedies similar to those imposed in the recent Reynolds $v$. Giuliani case. ${ }^{218}$

By contrast, legal accountability under TANF rests on much shakier terrain. The first question is whether TANF benefits are entitlements. Even if this question is answered in the affirmative, the state action doctrine poses a potential barrier to enforcement in privatized jurisdictions. Because the state action doctrine is founded on the principle of distinct public and private spheres, ${ }^{219}$ it is not amenable to the modern reality of public and private interdependence in social services. As a result, welfare advocates will likely have to enforce accountability of private welfare providers through a creative blend of other legal theories, each of which has serious shortcomings. ${ }^{220}$

215. See, e.g., Craig D. Feiser, Protecting the Public's Right to Know: The Debate Over Privatization and Access to Government Information Under State Law, 27 FlA. ST. U. L. REV. 825 (2000).

216. See Clayton P. Gillette \& Paul B. Stephan IIl, Constitutional Limitations on Privatization, 46 AM. J. Comp. L. 481, 493-96 (1998). They conclude that the federal Constitution as well as state constitutions pose few limits to contracting out. Id. at 501("Even in those areas where government may be required to play some role, there appears to be room for contracting out, so long as the contractual arrangements limit the discretion of the private firm."); see also Jody Freeman, The Private Role in Public Governance, 75 N.Y.U. L. REV. 543, 580-88 (2000); Robbins, supra note 211, at 544-77; Cass, supra note 213 , at $497-502$.

217. Goldberg v. Kelly, 397 U.S. 254 (1970).

218. See supra note 42 and accompanying text.

219. Although commentators disagree vehemently on the legitimacy of the public/private distinction, as well as where the line between public and private can be drawn (if at all), they agree that the distinction is what underlies the state action doctrine. See, e.g., Richard S. Kay, The State Action Doctrine, the Public-Private Distinction, and the Independence of Constitutional Law, 10 ConsT. Conmenr. 329, 330 (1993); Louis Michael Seidman, Public Principle and Private Choice: One Uneasy Case for a Maintenance Theory of Constitutional Law, 96 YALE L.J. 1006, 1011 n.18 (1987); Henry C. Strickland, The State Action Doctrine and the Rehnquist Court, 18 Hastings Const. L.Q. 587, 594-97 (1991).

220. See infra Part V (describing altematives in detail). 


\section{A. Due Process After TANF}

Prior to the enactment of TANF, it was well settled that AFDC benefits were an entitlement to which constitutional due process protections attached. ${ }^{221}$ Although the Court has refused to recognize a substantive constitutional right to welfare, ${ }^{222}$ in 1970 , the landmark case of Goldberg $v$. $K_{e l l y}{ }^{223}$ established that welfare benefits were a form of property and thus could not be terminated without the due process protections of prior notice and a hearing. Significantly, the Goldberg Court rejected the argument that welfare benefits were a "privilege," rather than a "right," and held that "[s]uch benefits are a matter of statutory entitlement for persons qualified to receive them."224

The concept of an entitlement was further defined in Board of Regents v. Roth, ${ }^{225}$ in which the Court explained that it is the nature, rather than the weight of the interest at stake, that determines whether due process protections apply. The Court stated, "[t]o have a property interest in a benefit, a person clearly must have more than an abstract need or desire for it. He must have more than a unilateral expectation of it. He must, instead, have a legitimate claim of entitlement to it."226 Legitimate claims of entitlement "are created and ... defined by existing rules or understandings that stem from an independent source such as state law ...."227 Rules create reasonable expectations of entitlements, while discretionary systems cannot. ${ }^{228}$

221. See supra note 217. Under the Fifth Amendment, the federal government may not deprive any person "of life, liherty, or property, without due process of law." U.S. CoNST. amend. V. The states are similarly bound under the Due Process Clause of the Fourteenth Amendment. U.S. CoNST. amend. XIV.

222. Dandridge v. Williams, 397 U.S. 471,487 (1970). This mle results from the Supreme Court's reading of the Constitution as providing negative rather than positive liberties. See DeShaney v. Winnebago County Dep't of Soc. Servs., 489 U.S. 189, 196 (1989) (holding that the Fourteenth Amendment does not afford any "affirmative right to governmental aid, even where such aid may be necessary to secure life, liberty, or property interests of which the government itself may not deprive the individual"). By contrast, state constitutions may provide a basis for claiming an affirmative constitutional right to public assistance. See Helen Hershkoff, Welfare Devolution and State Constitutions, 67 Fordham L. Rev. 1403 (1999). Hershkoff points to the New York Constitution, which requires the State to provide for "'[t]he aid, care and support of the needy." Id. at 1410. However, state courts have generally deferred to legislative decisions on how to effectuate such constitutional requirements and have not imposed higher standards even where the statutory program fails to provide adequate subsistence to the poor. Id. at 1408-09.

223. 397 U.S. 254 (1970).

224. Id. at 262.

225. 408 U.S. 564 (1972). In Roth, the Court held that an assistant professor teaching under a oneyear contact did not have a property interest in continued employment.

226. Id. at 577 .

227. Id. ("Thus, the welfare recipients in Goldberg v. Kelly... had a claim of entitlement to welfare payments that was grounded in the statute defining eligibility for them.").

228. See Cynthia R. Farina, On Misusing "Revolution" and "Reform": Procedural Due Process and the New Welfare Act, 50 ADMIN. L. REv. 591, 613 (1998) ("Roth entitlement analysis channeled the constitutional inquiry into scrutinizing the representations that regulatory government chooses to make to its citizens."); Nancy Morawetz, A Due Process Primer: Litigating Government Benefit Cases 
Thus, where courts conclude that the decision-maker has unfettered discretion in awarding the public benefit, they will not find an entitlement. ${ }^{229}$ As a result, the search for entitlement status requires a careful parsing of the statute creating the benefit in a search for substantive standards that constrain the discretion of the official decision-maker. ${ }^{230}$

One consequence of this positive law conception of due process is that it allows apphicants for benefits, as well as recipients, to claim a legitimate expectation of entitlement. ${ }^{231}$ Where the law sets forth objective criteria for the receipt of benefits, an applicant who meets the criteria has a "reasonable expectation" of their receipt. ${ }^{232}$ However, the Roth test also creates the perverse outcome that the more discretion a decision-maker has in administering a government benefit, the less likely that benefit is to obtain entitlement status. ${ }^{233}$ Moreover, the positivist approach gives the legislature control over whether an entitlement is created, thereby leaving the poor entirely at the mercy of the political process. ${ }^{234}$

in the Block Grant Era, 30 CleaRINGHouse Rev. 97, 104 (1996) ("Under Roth a critical inquiry in determining the applicability of due process guarantees will be whether the state program is rule based or discretionary.").

229. Compare Eidson v. Pierce, 745 F.2d 453 (7th Cir. 1984) with Ressler v. Pierce, 692 F.2d 1212 (9th Cir. 1982). Both courts were deciding whether plaintiffs eligible for federally subsidized housing had an entitlement to the housing. The Eidson court concluded that there was no entitlement because the private landlords had discretion to select tenants from among a broad class of eligible applicants. Because "[t]he law does not tell the owner how to choose between two eligible individuals," a hearing officer would be unable to offer any remedy. 745 F.2d at 460-61. By contrast, the Ressler court found that an entitlement existed under the same program because "the regulations and guidelines promulgated pursuant to the statute closely circumscribe an owner's discretion." 692 F.2d at 1215. Despite their contrary outcomes, both courts agreed that discretion was the key factor.

230. See, e.g., Hewitt v. Helms, 459 U.S. 460, 470-72 (1983). The Court did not have to establish this positivist conception of entitlements, i.e., a conception under which non-constitutional "rules or understandings" define entitlements. Rather, the Court could have established a substantive Fourteenth Amendment right to welfare. The reasons why the Court did not choose this approach are well documented in Elizabeth Bussiere, (Dis)Entitling the Poor: The Warren Court, Welfare Rights, AND THE AMERICAN Political TRADITION (1997).

231. The Supreme Court has never squarely addressed this issue. See Am. Mfrs. Mut. Ins. Co. v. Sullivan, 526 U.S. 40, $61 \mathrm{n} .13$ (1999) (stating that since the plaintiffs did not contend they had a property interest in their claims, as distinct from their benefits, the Court would not reach the issue). Nonetheless, the logic of Roth compels such a result aud the lower federal courts have so held. See Laurence H. Tribe, American Constitutional Law 690 \& n.37 (2d ed. 1988); Morawetz, supra note 228 , at 99 n.11. Applicants, however, may be entitled to less process than recipients. See id. at 105-06.

232. See, e.g., Daniels v. Woodbury County, 742 F.2d 1128, 1132 (8th Cir. 1984) (holding that applicants for general assistance have a right to due process); Griffeth v. Detrich, 603 F.2d 118, 121 (9th Cir. 1979) (same); Holbrook v. Pitt, 643 F.2d 1261, 1278 \& n.35 (7th Cir. 1981) (collecting eases).

233. The opposite should be true given that due process serves as a restraint on arbitrary and unfair governmental action. See, e.g., Fuentes v. Shevin, 407 U.S. 67, 97 (1972) (due process is meant to minimize "unfair and mistaken deprivations"); Boddie v. Connecticut, 401 U.S. 371, 374 (1971) ("Perhaps no characteristic of an organized and cohesive society is more fundanental than its erection and enforcement of a system of rules defining the various rights and duties of its members, enabling thein to govern their affairs and definitively settle their differences in an orderly, predictable manner.").

234. BussiERE, supra note 230, at 156 ("The principle established by the Warren Court that welfare is a statutory and not constitutional entitlement produced some important benefits for the poor, 


\section{TANF's Entitlement Status}

The political process was not kind to welfare recipients in the PRA. Congress states unequivocally in the statute that benefits are not entitleinents, and that the law "shall not be interpreted to entitle any individual or family to assistance under any State program funded under [the Act]. ${ }^{235}$ Several states enacted statutes with similar language, ${ }^{236}$ although some states used contrary language expressly preserving the entitlement status of welfare benefits. ${ }^{237}$ As soon as the PRA was passed, the "no entitlement" language attracted intense scholarly attention because of its implications for TANF claimants' due process rights. Most scholars who have considered the issue, ${ }^{238}$ as well as the only two courts to address it, ${ }^{239}$ have concluded that TANF benefits are still entitlements. Their reasoning is simple: the existence of an entitlement depends on the substantive standards set forth in the statute, not on the legislature's characterization of those stan-

but is has also meant that AFDC mothers' legal claims to subsistence have ultimately been dependent on the sustained sympathy of the electorate and elected officials.").

235. Pub. L. No. 104-193, $\$ 401,110$ Stat. 2105,2113 (1996) (amending 42 U.S.C. $\$ 601$ (b)). This statement is not surprising given that, throughout American history, opponents have attacked public outdoor relief (or direct money payments) for giving the poor too much of a sense of entitlement and thereby encouraging them to agitate for their rights. See supra Part II.A.

236. See, e.g., ARIz. REv. STAT. ANN. § 46-291 (West 2000) ("Notwithstanding the fulfillment of the eligibility requirements for any component of temporary assistance for needy families, an individual is not entitled to services or benefits under temporary assistance for needy families.'); FLA. STAT. ANN. $\S 414.025(5)$ (West 1998) ("This chapter does not entitle any individual or family to assistance under the WAGES Program or Title IV-A of the Social Security Act, as amended."); WIS. STAT. ANN. \$ 49.141(4) (West 2000) ("Notwithstanding fulfillment of the eligibility requirements for any component of Wisconsin works, an individual is not entitled to services or benefits under Wisconsin works.").

237. See, e.g., MD. ANN. CODE of 1957 art. 88A, § 50(c) (2000) (" Entitlement. -All recipients meeting the requirements of the [Family Investment Program] shall be entitled to cash assistance benefits.").

238. See Farina, stupra note 228 , at $622-23$ (finding that the Roth entitlement is now located in implementing state law rather than in federal statutory provisions); Melissa Kwaterski Scanlan, The End of Welfare and Constitutional Protections for the Poor: A Case Study of the Wisconsin Works Program and Due Process Rights, 13 BERKeley WoMEN's L.J. 153, 175-76 (1998) (concluding that Wisconsin law creates an entitlement to TANF benefits); Laura C. Conway, Student Research, Will Procedural Due Process Survive After Aid to Families with Dependent Children is Gone?, 4 GEo. J. ON FIGHTING PoverTy 209, 213-16 (1996) (holding that state laws may provide reasonable expectation of benefits, thus creating an entitlement); Kennedy, supra note 6, at 280-86 (Goldberg still governs receipt of benefits). But see Michelle L. VanWiggeren, Experimenting with Block Grants and Temporary Assistance: The Attempt to Transform Welfare by Altering Federal-State Relations and Recipients' Due Process Rights, 46 EMORY L.J. 1327, 1357-61 (1997) (concluding that "no entitlement" language destroys any reasonable expectation to a legitimate claim of entitlement); Richard J. Pierce, Jr., The Due Process Counterrevolution of the 1990s?, 96 Colum. L. Rev. 1973 (1996) (concluding that welfare benefits are not entitlements under federal law, but ignoring claims based on state laws).

239. Reynolds v. Giuliani, 35 F. Supp. 2d 331 (S.D.N.Y. 1999) (finding implicitly that New York State TANF benefits are entitlements by ruling that their deprivation violated the due process clause). ln Weston $v$. Hammons, a Colorado state eourt judge issued a bench ruling on May 28, 1999 that Colorado TANF benefits are a proteeted property interest to which due process requirements apply, despite "no entitlement" language in the Colorado TANF statute. See Welfare News, Colorado Court Rules That Due Process Applies to TANF Benefits Despite "No Entitlement" Language (June 1999), available at $\mathrm{http} / / \mathrm{www}$.welfarelaw.org/coloradocourt.htm. 
dards. ${ }^{240}$ TANF requires that states "set forth objective criteria for the delivery of benefits and the determination of eligibility and for fair and equitable treatment. ${ }^{9241}$ In turn, these objective criteria create a legitimate expectation of receipt of TANF funds for those meeting the criteria, and thus constitute an entitlement.

Moreover, it is not clear that Congress intended the "no entitlement" language to extinguish due process rights. The House Report accompanying the PRA stated that, "[r]emoving the individual entitlement to cash benefits, which is a critical aspect of the block grant approach to social policy, sends a clear message to recipients that benefits are temporary and are not intended to keep families dependent on public benefits year after year."242 This behavior modification purpose is in no way contravened by providing fair process rights to recipients during the time they are eligible for the program; rather, given the time limits on receipt of benefits, the need for accuracy in their distribution is all the greater.

In the context of TANF benefits, the eligibility standards in state welfare laws appear to constrain sufficiently the discretion of the decisionmakers such that the benefits are an entitlement. The state statutes set forth, in detail, the various eligibility criteria for their programs, including income, family composition, family size, citizenship status, total years on welfare, and participation in work. ${ }^{243}$ The statutes do not permit front-line workers to award limited benefits by choosing at will among a class of eligible applicants, a form of discretion that has defeated the creation of an entitlement in other types of public benefits cases. ${ }^{244}$ Nor do the statutes

240. See Farina, supra note 238 , at 620 ("[T] created a constitutionally protected interest is surely for the judiciary."); see also Washington Legal Clinic for the Homeless v. Barry, 107 F.3d 32, 38 (D.C. Cir. 1996) ("[W]e doubt that blanket "noentitlement' disclaimers can by themselves strip entitlements from individuals in the face of statutes or regulations unequivocally conferring them ....").

Similarly, once it has created an entitlement, a legislature cannot authorize the deprivation of that entitlement through constitutionally inadequate procedures. Cleveland Bd. of Educ. v. Loudermill, 470 U.S. 532, 541 (1985). Accordingly, beneficiaries need not take "“the bitter with the sweet." Id.; cf. Lebron v. Nat'l R.R. Passenger Corp., 513 U.S. 374, 392 (1995) ("If Amtrak is, by its very nature, what the Constitution regards as the Government, congressional pronouncement that it is not such can no more relieve it of its First Amendment restrictions than a similar pronouncement could exempt the Federal Bureau of Investigation from the Fourth Amendment.").

241. Pub. L. No. 104-193, \$ 402(a)(1)(B)(iii), 110 Stat. 2105,2114 (1996) (codified at 42 U.S.C. $\$$ 602) (emphasis added).

242. H.R. REP. No. 104-651, at 1328 (1996), reprinted in 1996 U.S.C.C.A.N. 2183, 2387.

243. See, e.g., ARIz. Rev. STAT. ANN. \$\$ 46-292 (eligibility for assistance); 46-294 (duration of assistance); 46-296 (eligibility for assistance; unwed minor parents); 46-299 (jobs program; definition) (West 2000).

244. See, e.g., Eidson v. Pierce, 745 F.2d 453 (7th Cir. 1984), discussed supra note 229. The Eidson court carefully limited the scope of its ruling:

We do not mean to suggest that any element of discretionary judgment in determining the receipt of public benefits would defeat an asserted property interest. Elements of discretion or judgment are often involved in the application of legal criteria, and a hearing or judicial review might ensure that the discretion was exercised in accordance with the relevant criteria. 
permit a front-line worker arbitrarily to cut off a recipient, another potentially lethal blow to the creation of an entitlement. At a minimum, state laws require that sanctions and terminations be imposed only for "good cause."245 While this gives substantial discretion to a front-line worker, that discretion can be reviewed for abuse or arbitrariness. ${ }^{246}$

Thus, it appears that Congress has chosen a system like that envisioned by scholars Jerry L. Mashaw and Dylan S. Calsyn:

We can imagine a Congress that wants to assist persons with below poverty level incomes, but that is uncertain how best to do so. And we can imagine such a Congress partially funding all state efforts directed at the relevant population. But even in this very loosely defined 'poverty block grant,' we cannot imagine how the national purposes could be consistent with indifference about whether some persons are arbitrarily excluded from whatever programs the states devise. To that extent those beneficiaries should have an entitlement, that is, a legal right secured by appropriate legal remedies. ${ }^{247}$

That the PRA creates such an entitlement is supported by Congress' continued cominitment to providing recipients with fair procedures, as expressed in Section 402 of the PRA..$^{248}$

\section{State Practices Under TANF}

The search for an entitlement under TANF is not merely an academic concern. Rather, it appears that several state statutes enacted after TANF fail to provide the level of due process contemplated by Goldberg. For instance, in Wisconsin, benefits can be denied, reduced, or terminated without prior notice or a hearing. ${ }^{249}$ As a result, a beneficiary contesting an erroneous decision can go for sixty-eight days, if not longer, without benefits as his or her appeal winds through the system. ${ }^{250}$ Furthermore, departmental level review is only required when front-line workers deny an

Id. at 462.

245. The PRA requires that if an individual refuses to work, the state shall reduce or terminate assistance "subject to such good cause and other exceptions as the State may establish." $§ 407(e)(1)(B)$, 110 Stat. at 2129 (codified at 42 U.S.C. $\$ 607(\mathrm{e})$ ).

246. Even if TANF benefits are entitlements, the question remains what level of process is due. Mathews v. Eldridge, 424 U.S. 319 (1976). Under Mathews, a court must balance the interests of the plaintiffs with the government interests at stake and the value of any added procedures. For further analysis of the process that may be due to TANF beneficiaries, see Morawetz, supra note 228, at 106; Conway, supra note 238 , at 219-21.

247. Jerry L. Mashaw \& Dylan S. Calsyn, Block Grants, Entitlements, and Federalism: A Conceptual Map of Contested Terrain, 14 YALE J. ON REG. 297, 323 (1996).

248. See $\$ 402(a)(1)(B)(i i i), 110$ Stat. at 2114 (codified at 42 U.S.C. $\S 602$ ).

249. See Scanlan, supra note 238, at 191-94 (describing constitutional flaws in Wisconsin's welfare reform statute); WIS. STAT. ANN. $\$ 49.152$ (West 2000) (stating that review of adverse action occurs after the action is taken).

250. See Scanlan, supra note 238 , at 191. 
application for failure to meet financial eligibility requirements. ${ }^{251}$ Even in those cases, the administering agency need not provide an opportunity for the parties to be heard or for cross-examination. ${ }^{252}$ Meanwhile, in Arizona, private welfare agencies are authorized to draft their own rules for hearing procedures, which opens the door to a complete lack of accountability to claimants and the public at large. ${ }^{253}$

Even in those states with fairly comprehensive notice and hearing procedures, there is mounting evidence that the agencies carrying out those statutes, both public and private, are not complying with the law. ${ }^{254}$ One welfare rights organization reports that "programs [are] being operated without clear and understandable eligibility standards," that there has been "a general decline $\mathrm{m}$ the adequacy and timeliness of notices," and that "too many states are operating their TANF programs with insufficient standards and inadequate oversight of the work of the staff charged with implementing welfare reform." 255 As discussed earlier, a class of New York welfare recipients successfully challenged these sorts of deficiencies. ${ }^{256}$ But could such a suit be brought in a privatized jurisdiction such as Milwaukee, Phoenix, or Los Angeles?

\section{B. The State Action Dilemma}

Despite the intense and immediate attention given to the entitlement issue, scholars have ignored the fact that many TANF benefits are, or soon will be, distributed by private entities. ${ }^{257}$ Since constitutional protections

251. WIS. STAT. ANN. $\$ 49.152(2)$ (c) (West 2000). However, the statute does permit agency level fact-finding hearings for all timely petitions. Id. $\$ 49.152(2)(a)$.

252. Scanlan, supra note 238, at 192-93.

253. Ariz. Rev. Stat. AnN. \$ 46-349D (West 2000).

254. See Welfare News, Due Process and Fundamental Fairness in the Aftermath of Welfare Reform (Sept. 1998), available at http://www.welfarelaw.org/DueProcess.htm.

255. Id.; see also Family Investment Program Legal Clinic, Time Out! A Status Report on Welfare Reporm in Baltimore City at the Three Year Mark, As Experienced by Those It Was Intended to Help and Their Legal Advocates (1999). This report details bureaucratic barriers to the receipt of benefits imposed at Maryland's local social services offices, including needless and frequent re-determinations of eligibility, long waits in waiting rooms, and discouragement of filing appeals, among other things.

256. See supra notes $16-43$ and accompanying text.

257. By contrast, there is a substantial body of literature discussing the state action doctrine with regard to other privatization efforts. See, e.g., Richard C. Reuben, Public Justice: Toward a State Action Theory of Alternative Dispute Resolution, 85 CALIF. L. REv. 577 (1997); David A. Sklansky, The Private Police, 46 UCLA L. Rev. 1165 (1999); Richard L. Stone \& Michael A. Perino, Not Just a Private Club: Self-Regulatory Organizations As State Actors When Enforcing Federal Law, 1995 Colum. Bus. L. Rev. 453 (1995). Although David Kennedy provides an informative discussion of the technological changes wrought by welfare reform, including the use of electronic benefit transfer to give monetary benefits to recipients, and although he still sees a role for Goldberg in providing due process protections, he ignores the issue of whether the private providers (whom he eschews) are state actors. See generally Kennedy, supra note 6. 
only apply to state actors, ${ }^{258}$ welfare beneficiaries seeking to enforce due process protections in a privatized system must overcome the hurdle of establishing that their private welfare providers are state actors. ${ }^{259}$ Likewise, Section $1983,{ }^{260}$ which provides the statutory vehicle for remedying constitutional and federal statutory violations committed by state actors, reaches only those deprivations of federal rights that occur "under color of law," and excludes "merely private conduct no matter how discriminatory or wrongful." $" 261$

State action is clearly present when a state employee acting in her official capacity pursuant to state law deprives a person of constitutional rights. However, when government officials carry out their programs with the assistance or participation of private persons, as is increasingly the case in the provision of social services, the state action issue becomes more difficult. Privatization poses a challenge to the state action doctrine because it blurs the line, upon which much of our constitutional

258. See The Civil Rights Cases, 10 U.S. 3, 10-14 (1883); Ronald J. Krotoszynski, Jr., Back to the Briarpatch: An Argument in Favor of Constitutional Meta-Analysis in State Action Determinations, 94 MicH. L. Rev. 302, 303 (1995) ("Since at least 1879, the Court has consistently held that the guarantees of both the Fourteenth Amendment and the Bill of Rights protect citizens only from acts committed by the government, and has required plaintiffs asserting claims under these provisions to establish the presence of 'state action' before undertaking an analysis of the merits of a particular claim.").

259. One of the few comprehensive attempts to address the implications of social service privatization on the state action doctrine can be found in Daphne Barak-Erez, A State Action Doctrinc for an Age of Privatization, supra note 6. Barak-Erez recommends that state action be found where (1) the function is public in nature according to current understandings, and (2) the service is supplied by a private monopoly. Id. at 1192 . Although she accurately points out the weaknesses inherent in the state action doctrine, her approach is flawed for at least three reasons. First, there is little consensus on what actions are public in nature given that historically most social services have been provided by both private and public entities. Second, her approach would freeze the public function doctrine based upon the current conception of govemment's role. But as TANF demonstrates, conceptions of the government's role change quickly. Finally, looking at the monopolistic status of the privately provided public service ignores the reality that most social services are provided by a complicated mix of public and private entities.

260. Rev. Stat. $\S 1979,42$ U.S.C. $\$ 1983$ (1996).

261. Blum v. Yaretsky, 457 U.S. 991, 1002 (1982). Section 1983 provides a damages remedy only for unlawful acts of governmental policy makers or acts taken pursuant to official governmental policies. See City of St. Louis v. Praprotnik, 485 U.S. 112 (1988). Section 1983 generally does not reach conduct committed by individual local government officials because it does not provide for respondeat superior liability. See Monell v. Dep't of Soc. Servs., 436 U.S. 658, 694 (1978). However, where individual wrongful incidents are widespread, the conduct may be attributable to the govemmental entity. See, e.g., Samuels v. District of Columbia, 770 F.2d 184 (D.C. Cir. 1985), remanded to 669 F. Supp. 1133, 1137-40 (D.D.C. 1987) (public housing authority's failure to implement grievance procedure was so widespread that housing authority could not claim that delays were isolated incidents of lower level employees failing to follow official policy). Moreover, those courts to consider the issue have determined that the Monell "official policy or custom" requirement does not apply where plaintiffs are seeking prospective injunctive relief. See Reynolds v. Giuliani, 2000 WL 1013952, *7-8 (S.D.N.Y. 2000) (describing caselaw). 
jurisprudence is based, between private and governmental action. ${ }^{262}$ At least in the area of social services, the government cannot deliver services without the use of private providers, and the providers cannot operate without governmental funding. In addition to this interdependency, the public and private actors often share responsibility for carrying out these public functions. Thus, while TANF applicants and recipients are likely entitled to due process protections when interacting with government welfare agencies, the question remains whether those same protections apply when a private entity administers federal entitlements. More pointedly, can private parties distribute public entitlements under contract with state and local governments free froin constitutional restraints? And can state and local governments insulate themselves froin liability by contracting out their welfare programs?

\section{The State Action Tests}

The answers to these questions are neither simple nor encouraging. In Lugar v. Edmondson Oil Co., the Court set forth a two-part test for analyzing when private conduct is "fairly attributable" to the State such that constitutional protections apply. ${ }^{263}$ First, the Court asks whether the alleged constitutional deprivation was "caused by the exercise of some right or privilege created by the State or by a rule of conduct inposed by the State or by a person for whom the State is responsible."264 Satisfying this part of the test is easy in the context of privatized welfare. Private welfare offices operate solely by virtue of a "right or privilege created by the State," namely, the state statute establishing and regulating the welfare program as well as the contract between the State and private provider.

Second, the Court asks whether "the party charged with the deprivation [is] a person who inay fairly be said to be a state actor."265 This prong essentially reiterates the state action requirement and does not itself provide content to the inquiry. Rather, as the Court has acknowledged, "[o]nly by sifting facts and weighing circumstances can the nonobvious involvement of the State in private conduct be attributed its true significance."266 To guide this fact-specific analysis, the Court looks primarily at two

262. Although the public/private distinction is central to our constitutional scheme, numerous scholars have pointed out that it is analytically impossible to isolate private from public action, given the government's role in nearly every aspect of private life. See, e.g., G. Sidney Buchanan, $A$ Conceptual History of the State Action Doctrine: The Search for Governmental Responsibility (pts. 1 \& 2), 34 Hous. L. REv. 333 (1997), 34 Hous. L. REv. 665, 724 (1997) (“[E]very action engaged in by a private person is either compelled, prohibited, or permitted, i.e., authorized, by the legal system within which that person lives."); Cass, supra note 213, at 503-04; Freeman, supra note 216, at 565, 564-71

("There is neither a purely public nor purely private realm. There is only interdependence.").

263. 457 U.S. 922 (1982).

264. Id. at 937 .

265. Id.

266. Burton v. Wilmington Parking Auth., 365 U.S. 715, 722 (1961). 
factors: (1) the degree of state involvement with the challenged private action (the "nexus" analysis), ${ }^{267}$ and (2) whether the private actor is carrying out a public function (the "public function" analysis). Under the nexus test, state action exists where the state "has exercised coercive power or has provided such significant encouragement, either overt or covert, that the choice must in law be deemed to be that of the State."268 Under the public function test, state action will be found where a private entity is carrying out a function traditionally and exclusively performed by the state. ${ }^{269}$ These tests are designed to police the boundary between public and private. ${ }^{270}$ While the law on state action is far from a model of clarity, ${ }^{271}$ the Court has made quite clear that state action will be found under only limited circumstances. ${ }^{272}$

The most relevant Supreme Court state action cases for the welfare privatization context are Blum v. Yaretsky ${ }^{273}$ and Rendell-Baker v. Kohn. ${ }^{274}$ Both of these cases, handed down the same day in 1982, involved private entities funded by the government, which provided public services to needy, dependent populations pursuant to state law. In neither case did the court find state action. In Blum, a class of Medicaid recipients challenged their private nursing homes' decisions to discharge or transfer them to a

267. Variations of this inquiry have been altematively referred to as the symbiotic relationship test, the governmental involvement test, the nexus test, and the joint participation test. See generally Sheldon H. Nahmod, Civil Rights and Civil Liberties Litigation: The Law of Section 1983 \$\$ 2:6-2:10 (4th ed. 1999).

268. Am. Mfrs. Mut. Ins. Co. v. Sullivan, 526 U.S. 40, 52 (citing Blum v. Yaretsky, 457 U.S. 991 , 1004 (1982)). The nexus test is applied in Blum and in Rendell-Baker v. Kohn, 457 U.S. 830 (1982), both of which are discussed in detail infra.

269. American Manufacturers, 526 U.S. at 55 . The classic public function case is Marsh v. Alabama, 326 U.S. 501 (1946), discussed infra note 284.

270. Professor Chemerinsky has argued that this boundary is unjustified and that the Constitution should protect against certain abuses of private power.

[T] he concentration of wealth and power in private hands, for example, in large corporations, makes the effect of private actions in certain cases virtually indistinguishable from the impact of governmental conduct. Just as people may need protection from government because its power can inflict great injuiries, so must there be some shield against infringements of basic rights by private power.

Erwin Chemerinsky, Rethinking State Action, 80 N.W.U.L. REv. 503, 510-11 (I985) (footnote omitted).

271. Commentators have heaped scom on the Court's state action doctrine. See, e.g., Krotoszynski, supra note 258 , at $303 \& \mathrm{n} .13$ ("The state action doctrine, with its intricate mantras and talismanic phrases, has been and remains a dark thicket of constitutional law.").

272. Some scholars have argued for the abolition of the current state action doctrine and have urged instead that courts balance the interests of the alleged violator and the violatee. See generally Chemerinsky, supra note 270; Robert J. Glennon Jr. \& John E. Nowak, A Functional Analysis of the Fourteenth Amendment "State Action" Requirement, 1976 Sup. CT. Rev. 22 I, 231-32, 259 (stating that courts should balance "value of a challenged nongovernmental practice against the harm it does to a given right and the value of that asserted right"); Jerre S. Williams, The Twilight of State Action, 41 TEx. L. Rev. 347, 373 (1963).

273. 457 U.S. 991 (1982).

274. 457 U.S. 830 (I982). 
lower level of care without notice or an opportunity for a hearing. ${ }^{275} \mathrm{Al}$ though the state subsidized the costs of the nursing homes, extensively regulated the operation of the homes, required the homes to periodically assess the appropriate level of care for residents, paid the medical expenses of more than ninety percent of the patients, and licensed the facilities, the Court held that these contacts were insufficient to make the nursing homes state actors. ${ }^{276}$ The Court's decision hinged on the fact that the challenged decisions turned on "medical judgments made by private parties according to professional standards that are not established by the State." ${ }^{.77}$ The Court also made short shrift of the assertion that the nursing homes performed a public function, stating that neither the state constitution nor the Medicaid statute required New York to provide skilled nursing services. ${ }^{278}$

Similarly, the Court's focus on the private actor's discretion in decision making and its rejection of extensive regulation as a source of state action were determinative in Rendell-Baker. There, former employees of a private, nonprofit school that served special needs students sued the school for firing them, allegedly in violation of their free speech rights and without adequate procedural protections. ${ }^{279}$ Public funds accounted for $90 \%$ of the school's funding, state and local school districts regulated the school, and the school operated pursuant to a written contract with the local school system and state agencies. ${ }^{280}$ Nevertheless, the Court held that these contacts did not amount to "coercive power" or "significant encouragement" sufficient to constitute state action. ${ }^{281}$

The Court also rejected the teachers' public function argument. Although it agreed that education of maladjusted high school students is literally a public function, the Court held the fact " $t]$ hat a private entity performs a function which serves the public does not make its acts state action." 282 Rather, "the question is whether the function performed has been "traditionally the exclusive prerogative of the State."'283 Since the

275. Blum, 457 U.S. at 991.

276. Id. at 1006-09.

277. Id. at 1008 .

278. Id. at 1011. Moreover, the Court reasoned that even if the State had an obligation to provide those services, the nursing home's day-to-day decisions were not the type of decisions "traditionally and exclusively made by the sovereign for and on behalf of the public." Id. at 1012 .

279. Rendell-Baker, 457 U.S. at \$34-35.

280. Id. at \$31-34.

281. In a particularly poor analogy, the Court compared the school to other "private corporations whose business depends primarily on contracts to build roads, bridges, dams, ships, or submarines," none of whom become state actors by reason of their performance of public contracts. Id. at $\$ 40-41$. Yet as the dissent pointed out, ship and bridge builders do not perform public duties pursuant to statute, nor do they implicate constitutional values. Id. at $\$ 51$.

282. Id. at 842 .

283. Id. (citation omitted). The exclusivity test was first announced in Jackson v. Metro. Edison Co., 419 U.S. 345 (1974), in which the Court held that a private utility operating under a publicly 
legislature gave school districts the choice of either providing those services themselves or paying private schools to do so, the provision of those services was not the exclusive province of the state. Of course, under this reasoning, the public function exception to the state action doctrine threatens to swallow itself. If a legislature gives the executive branch the choice of providing a service publicly or privately, then the service at issue cannot be deemed to be an "exclusive" function of the state. ${ }^{284}$ By its terms, then, it is hard to see how a privatized service can ever satisfy this interpretation of the public function test.

\section{A Critique of the State Action Tests}

The Court has devised various state action tests, such as those applied in Blum and Rendell-Baker, to sift through the complicated web of private and public interrelationships and to identify those actions properly subject to constitutional constraints. Gradually, these tests have taken on a life of their own, ${ }^{285}$ such that the Court now assumes that running the facts of a given case through the gauntlet of state action tests will produce a result in keeping with the underlying purposes of the state action doctrine.

In Lugar v. Edmondson Oil Co., the Court identified the dual purposes of the state action doctrine: to preserve a sphere of individual freedom and to avoid holding states liable for conduct "for which they cannot fairly be blamed." ${ }^{286}$ With regard to the former purpose, the Court has stated: "One

granted monopoly was not a state actor, and thus did not have to provide due process to a customer before terminating her electric service.

284. The paradigmatic public function case is Marsh v. Alabama, 326 U.S. 501 (1946), in which the Court held that a town wholly owned by a corporation was a state actor and thus could not prohibit a Jehovah's Witness from passing out religious literature in the town. During the early 1990s, the Supreme Court appeared to back away from the requirement of exclusivity in the public function test in two cases in which the court held that the exercise of peremptory challenges by private litigants constituted state action. See Edmonson v. Leesville Concrete Co., 500 U.S. 614 (1991) (holding that the exercise of peremptory challenges constitutes state action in civil cases); Georgia v. McCollum, 505 U.S. 42 (1992) (same holding for criminal cases). However, the Court's recent decision in American Manufacturers Mutual Ins. Co. v. Sullivan, 526 U.S. 40, 55 (1999), seems to have revived and reinforced the exclusivity requirement. The few functions that may fall within the Court's exclusivity test include holding elections, empanelling juries, and operating jails and prisons. See Krotoszynski, supra note 258, at 318; see also Street v. Corrs. Corp. of America, 102 F.3d 810, 814 (6th Cir. 1996) (finding private prison guard to be a state actor); Blumel v. Mylander, 919 F. Supp. 423, 426-27 (M.D. Fla. 1996) (same).

285. Acknowledging the plethora of state action tests (including the "public function" test, the "state compulsion" test, the "nexus" test, and the "joint action" test), the Court in Lugar commented, "[w]hether these different tests are actually different in operation or simply different ways of characterizing the necessarily fact-bound inquiry that confronts the Court in such a situation need not be resolved here." 457 U.S. 922 , 939 (1982). One insightful jurist commented that the vocabulary of state action "is composed entirely of malleable concepts, contractable and expandable depending on how the judge feels. These 'tests' are all pigeonholes and labels; they lack clarity. In application, they provide the illusion of precision." Adams v. Vandemark, 855 F.2d 312, 320 (6th Cir. 1988) (Merritt, J., dissenting).

286. Lugar, 457 U.S. at 936. 
great object of the Constitution is to permit citizens to structure their private relations as they choose subject only to the constraints of statutory or decisional law."287 At the same time, the second purpose helps preserve federalism interests by allowing the states to govern free of unwarranted federal court influence. Together, these two purposes "require the courts to respect the limits of their own power as directed against state governments and private interests."28s

Assuming the validity of these purposes, ${ }^{289}$ Blum and Rendell-Baker demonstrate the discrepancy between the state action tests and their supposed purposes. ${ }^{290}$ In Blum, the patients sued state officials over the fairness of procedures established by state regulations. As the court recognized, a finding of state action would have required the state to change its regulations to provide for notice and a hearing before transferring patients to lower levels of care. Such a result would be entirely in keeping with the purposes of the state action doctrine. It would mean that the state actors were liable for issuing unconstitutional regulations, matters precisely within their control. Moreover, a change in the state regulations would not have interfered with the "imdividual freedom" of the doctors to make medical assessments based on their independent judgment. ${ }^{291}$ Rather, such a change would have constrained what state officials could do based on those assessments. In other words, notice and hearing requirements would simply give the nursing home residents an opportunity to present evidence contrary to the independent medical assessments of the doctors. Thus, Blum allows a state to farm out certain decisions to private parties and then use and enforce those decisions for its own benefit.

287. Edmonson v. Leesville Concrete Co., 500 U.S. 614, 619 (1991). As Professor Tribe has explained, individual freedom "is basic under any conception of liberty, but it would be lost if individuals had to conform their conduct to to the Constitution's demands." TRIBE, supra note 229, at 1691.

2S\$. Lugar, 457 U.S. at 936-37.

289. "Whether this is good or bad policy, it is a fundamental fact of our political order." Lugar, 457 U.S. at 937. Erwin Chemerinsky has argued that the state action doctrine does not serve these claimed purposes. He notes that the preservation of one person's right to violate a constitutional right comes at the expense of the victim's own individual liberty. Chemerinsky, supra note 270, at 536-42. Further, he argues that "[s]tate sovereignty is not sacrificed by federal protection of liberty." Id. at 545.

290. For a discussion of the purpose of the state action requirement in the structure of the Constitution, see Strickland, supra note 217, at 594-96. For discussions of the value of preserving a distinction between public and private action, see generally Kay, supra note 217; Barbara Rook Snyder, Private Motivation, State Action and the Allocation of Responsibility for Fourteenth Amendment Violations, 75 Cornell L. Rev. 1053, 1060-63 (1990); Martha Minow, Partners, Not Rivals?: Redrawing the Lines Between Public and Private, Non-Profit and Profit, and Secular and Religious, 80 B.U. L. REv. 1061, 1081 (2000) ("Commitment to some form of distinction between the public and private realm is also vital to a vibrant pluralist society.").

291. The actual individual freedom of the doctors is questionable in any event. As the dissent in Blum pointed out, the doctors were making formulaic assessments based on regulatory checklists provided by the state. 457 U.S. 991, 1019-28 (19\$2) (Brennan, J., dissenting). 
In Rendell-Baker, a finding of state action would have required the school to change its personnel procedures to comply with due process. Although such a change might interfere with the individual freedom of the school officials to do as they pleased, the school officials' right to hide behind the mantle of "individual freedom" is questionable. When the school officials decided to contract with state and local governmental employees to run the school, and when they accepted almost $95 \%$ of their funding from governmental sources, they gave up some of their "individual freedom" in exchange for valuable resources. ${ }^{292}$ Indeed, the Court hinted that it would likely deem the school to be a state actor with regard to heavily regulated student (as opposed to personnel) matters, thus implicitly conceding that the need to preserve individual freedom lessens once a private entity decides to administer a publicly funded program. ${ }^{293}$

Moreover, a finding of state action in Rendell-Baker would not have resulted in the state being held accountable for matters outside of its control. As a practical matter, no government officials were sued in the case, and the state thus faced no liability. To the degree that the case involved allegedly unconstitutional regulations, it would have been entirely fair to hold the state and its officials accountable. Furthermore, the Court's concern over limiting state liability, while valid, is lessened in a contracting regime, in which the state may require indemnification from private actors whose conduct results in state liability. In any event, given the lack of discretion-constraining standards governing employee relations in the laws at issue in Rendell-Baker, it was unlikely that the teachers had a due process right to a hearing even if the state action question had been answered in their favor. ${ }^{294}$ Thus, the better choice for the Court would have been to hold the school officials to be state actors, but to find that no constitutional violations had occurred. Such a ruling would have fully comported with the purposes of the state action doctrine.

Ironically, the Court's mechanical reliance on the state action tests results in a subversion of the doctrine's purposes even in those cases where the Court has found a private actor to be engaged in state action. In 1982, on the same day that the Court decided Blum and Rendell-Baker, the Court found in Lugar v. Edmondson Oil Co. that state action existed where private party debt claimants used state prejudgment attachment procedures that violated due process. ${ }^{295}$ Lugar was the very decision in which the

292. Some lower federal courts have cited the monetary benefits obtained by government contractors as one factor satisfying the nexus test. See, e.g., Swann v. Gastonia Hous. Auth., 675 F.2d 1342, 1346 (4th Cir. 1982); Anast v. Commonwealth Apts., 956 F. Supp. 792, 798-99 (N.D. III. 1997).

293. Rendell-Baker v. Kohn, 457 U.S. 830, 841-42 (1982).

294. In addition, the plaintiff probably had not alleged a sufficient First Amendment claim. See TRIBE, supra note 231 , at 1717 n. 15 .

295. The Court is generally more comfortable in finding state action where private parties make use of garnishment and prejudgment attachment procedures. In addition to Lugar, see, e.g., Sniadach 
Court explained the foundations of the state action doctrine. Yet the finding of state action in Lugar, based largely on application of the "joint participation" test, ${ }^{296}$ contravened the purposes of the doctrine set forth therein. The debtor in Lugar sued only the private debt claimant. He did not sue any of the state officials who sequestered his property after the creditor filed for and received prejudgment attachment. The Court's decision to hold the private creditor liable for doing no more than invoking a presumptively valid state attachment process undermined its supposed desire to uphold "individual freedom." As a result, the Court imposed liability on a private party for following an unconstitutional state law, while simultaneously allowing that law to stand. The properly liable parties were the state officials who enforced the unconstitutional state law, but they were not named as defendants in the case. Thus, in Lugar, hollow application of the state action "tests" resulted in a decision bearing no relationship to the actual violation-an unconstitutional state law-and placing the "blame" for the violation on the wrong party.

\section{Disentangling Liability}

The Court's dogmatic application of the state action tests has allowed it to skirt the question of who should be liable for what. The Court asks whether private conduct is "fairly attributable to the State," but never delineates whether liability follows from attribution. ${ }^{297}$ In Lugar, the Court

and N. Ga. Finishing, Inc. v. Di-Chem, Inc., 419 U.S. 601 (1975) (petitioner's due process rights were violated by state statutory garnishment procedure that allowed for garnishment based on affidavit without opportunity for notice or a hearing); Mitchell v. W.T. Grant Co., 416 U.S. 600 (1974) (court assumes that constitutional principles apply to sequestration of debtor's property by claimant pursuant to state law); Fuentes v. Shevin, 407 U.S. 67 (1972) (state prejudgment replevin statutes violated due process because they authorized seizure of property before notice and hearing to determine validity of a creditor's claim); Sniadach v. Family Fin. Corp., 395 U.S. 377 (1969) (prejudgment garnishment proceeding violated due process). It seems that where solid, tangible property is involved, the Court can more readily "see" the due process violation than where state-created entitlements are involved. Thus, despite the Court's acknowledgment of new forms of property (such as welfare benefits, state employment, licenses, and other intangibles), the Old Property/New Property distinction still seems to influence judicial thinking.

296. Under the "joint participation" test, "a private party's joint participation with state officials in the seizure of disputed property is sufficient to characterize that party as a 'state actor' for purposes of the Fourteenth Amendment." Lugar v. Edmondson OiI Co., 457 U.S. 922, 941 (1982).

297. One attempt to sort through the liability question can be found in Barbara Rook Snyder, Private Motivation, State Action and the Allocation of Responsibility for Fourteenth Amendment Violations, 75 CORNell L. REv. I053 (I990). She proposes that state action should be deemed violative of the Constitution in two categories of cases:

first, when the acts of state actors provide the impetus for private conduct that would be unconstitutional if done directly by the state actors, and second, when the impetus for the alleged harm comes from the private party, but the state action would be unconstitutional had no private initiative been involved. Id. at 1056.

This approach would hold the state liable for enacting unconstitutional statutes that are then relied upon by private parties. However, in the absence of encouragement or compulsion, it would provide no relief in cases where a government contractor violates the law in a manner that would be 
suggested that private parties who make use of seemingly valid state laws subsequently held to be unconstitutional might have an affirmative, or good faith, defense. But this result would still make the private party bear the costs of litigation, as well as leave the offending statute in operation. At the same time, the state would face no liability for enacting the offending statute. A better solution would be to hold the state and its officials accountable for promulgating unconstitutional laws as well as for private conduct attributable to them, and to hold private parties who meet the state action test liable only for their own conduct. Although there may be no single test that can pinpoint those private actors whose conduct is appropriately attributable to the state, a private actor who contracts with the government to distribute a public entitlement has a sufficient nexus with the state to warrant the imposition of constitutional requirements on the private actor.

The Court recently exacerbated the confusion about who should be held liable for Section 1983 violations in its most recent state action decision, American Manufacturers Mutual Insurance Co. v. Sullivan. ${ }^{298}$ That case involved a challenge to Pennsylvania's workers' compensation statute, which permitted insurers to withhold payment of medical benefits while an independent review committee determined whether the medical treatment sought was "reasonable and necessary."299 The plaintiffs, a class of employees receiving benefits under the statute, alleged that the statutory scheme permitted the withholding of their benefits without prior notice and an opportunity to be heard. They sued various state officials who administered the Act, the director of the State Workers' Insurance Fund, the School District of Philadelphia (which self-insures its employees), and a number of private insurance companies providing workers' compensation coverage. ${ }^{300}$ The Court held that the private insurance companies that withheld the benefits pending the review committee's decision were not state actors. ${ }^{301}$

American Manufacturers is not strictly a privatization case, as it involves a heavily regulated private enterprise rather than the contracting out or transfer of governmental functions to a private entity. Nevertheless, the Court's heavy reliance on Blum and its continued narrow reading of the state action doctrine are relevant to the privatization issue. The Court reaffirmed that " $[\mathrm{t}]$ he mere fact that a business is subject to state regulation

unconstitutional if undertaken by state actors. Yet the receipt of government funds is what gives the private party the authority to undertake the challenged action in the first place. This transfer of power from the public to the private entity should result in some liability, and it should be placed upon the private party.

298. 526 U.S. 40 (1999).

299. Id. at 43 .

300. Id. at 47-48.

301. Id. at 43-44. 
does not by itself convert its action into that of the State." ${ }^{\prime 302}$ The Court then undertook an analysis of the nexus test, which asks "whether the State 'has exercised coercive power or has provided such significant encouragement, either overt or covert, that the choice must in law be deemed to be that of the State." ${ }^{\prime 303}$ The Court found no such nexus, reasoning that while the State statute authorized private insurers to withhold payment pending the determination of necessity and reasonableness, it did not mandate it. The Court noted that the private nursing facilities in Blum were just as extensively regulated as the private insurers in American Manufacturers, but that in both cases, "the state statutory and regulatory scheme leaves the challenged decisions to the judgnient of insurers." 304

American Manufacturers further exposes the Court's failure to distinguish between challenges to state procedures and challenges to private action. ${ }^{305}$ In American Manufacturers, the employees alleged that the statecreated procedures for resolving their worker's compensation claims were unfair. Rather than examine the state statute for procedural fairness, the Court examined the conduct of the private imsurers. Yet the conduct of the private insurers was not at issue and certainly could not be considered wrongful-they were merely following state law. It is not surprising then, that the Court refused to find them liable. Rather, the Court's error was cutting off the workers' characterization of their claim as a facial challenge to the utilization review procedures contained in the Act. While the private insurers were clearly the wrong target for such a challenge, the state actors, all of whom were named in the initial lawsuit, were not. Yet the Court granted certiorari only to the private insurers and not the state defendants, even though a ruling against the private insurers would have required the state actors to take remedial measures. Where a state has authorized the unconstitutional deprivation of an entitlement, a finding of state action does not subvert the purposes of the state action doctrine. The Court's ongoing refusal to focus on which entity is responsible for the alleged constitutional deprivation leads to the unfortunate result that, at least in some

302. Id. at 52 (quoting Jackson v. Metro. Edison Co., 419 U.S. 345,350 (1974)).

303. Id.

304. Id. at 58. The public function argument was also dismissed. The Court rejected the argument that the State had delegated powers traditionally reserved to the State to the private insurers, pointing out that the State was not obligated to provide either medical treatment or workers' compensation benefits to injured workers. Id. at 54-56. Moreover, the Court noted that prior to the enactment of the workmen's compensation statute, Pennsylvania common law allowed insurers to withhold payment for any reason at all. Id. at 56-57. The State simply never had a traditionally exclusive function of deciding whether to suspend payment for disputed medical treatment. Id.

305. For a detailed discussion of the Court's history of reviewing Section 1983 challenges to conduct authorized by state law, see Buchanan, supra note 262, at 356-64, 696-733. Buchanan frames this issue by asking "to what extent may government authorize, i.e., permit, one person or entity to harm another person or entity with legal impunity?" Id. at 696. He concludes that "the Supreme Court has failed to confront the state authorization issue openly and directly, and, in relation to that issue, may fairly be said to have adopted a stance of 'deliberate obfuscation."' Id. 
circumstances, government can avoid the strictures of due process by giving private parties the power to deprive individuals of entitlements.

\section{State Action Limits on Contracting}

One may well wonder whether the Court sees any limits on a government's ability to delegate away responsibility over a public entitlement to avoid accountability. In Rendell-Baker, the Court justified its holding by noting that " $[\mathrm{t}]$ here is no evidence that the State has attempted to avoid its constitutional duties by a sham arrangement which attempts to disguise provision of public services as acts of private parties. ${ }^{9306}$ Presumably then, with such evidence, the Court may have decided the state action question differently. ${ }^{307}$ Yet in the absence of evil intent, the Court apparently has little concern about a lack of due process when the government undertakes privatization for reasons of convenience, such as cost savings or increased efficiency.

Of course, from the beneficiaries' perspective, a denial of due process impacts them the same way whether the government privatizes for "evil" reasons or benign ones. Similarly, from the perspective of private contractors, their legal status should not hinge on the motives underlying the government's decision to privatize, even assuming those motives could be located in the complicated calculus and competing forces that go into such a decision. In fact, it is this mishmash of motives for privatizing that makes it difficult, if not impossible, to demonstrate that the state intended to insulate itself from liability as opposed to save costs, increase efficiency, or shrink the size of government.

One form of evidence that the Court has indicated it will accept as an indication of unlawful purpose is where the government creates a corporation and then seeks to avoid liability for the corporation's activities. In Lebron v. National Railroad Passenger Corp. ${ }^{308}$ the Court considered whether Amtrak, which was being sued for its advertising policies, was subject to the constitutional constraints of the First Amendment. The Court held that Amtrak was not merely a state actor, but rather an arm of government itself. In holding that government-created corporations are part of

306. 457 U.S. 830,842 n.7 (1982). Likewise, in Flagg Bros., Inc. v. Brooks, 436 U.S. 149 (1978), holding that a private warehouseman executing a lien pursuant to state law was not a state actor, the Court stated that "we express no view as to the extent, if any, to which a city or State might be free to delegate to private parties the performance of such functions and thereby avoid the strictures of the Fourteenth Amendment." Id. at 163-64.

307. Cf. Gillette \& Stephan, supra note 216 , at 481 . The authors assert that the government could not evade the Goldberg restrictions by converting welfare agencies into private contractors. They cite cases in which the Supreme Court disregarded the private status of schools that Southern states had converted to "private" in the 1960s to avoid desegregation. However, converting offices into private entities, as in the Lebron case, is different from contracting out and thus may not be subject to the same limits.

308. 513 U.S. 374 (1995). 
the government, the Court stated that "[i]t surely cannot be that government, state or federal, is able to evade the most solemn obligations imposed in the Constitution by simply resorting to the corporate form." ${ }^{309}$

Likewise, it could be argued that government should not be able to avoid constitutional obligations by contracting out. Nevertheless, the Court has never viewed contracting out to preexisting private corporate entities as raising the same types of risks as creation of a corporate entity by the government, perhaps because of its longstanding view that the abuse of public power raises more of a threat than the abuse of private power. ${ }^{310}$ However, the decision to contract may itself constitute abuse of governmental power, as may governmental abdication of any duty to oversee the performance of the contract. Moreover, in contracting cases, the private power is being exercised only because of a governmental grant of authority. In sum, while the Court has acknowledged that there may be limits on the government's ability to contract away liability, the Court is unlikely to recognize those limits in the welfare privatization context.

\section{The Lower Courts' Approach}

Despite Blum and Rendell-Baker, the lower federal courts have occasionally found state action to exist in public benefits schemes that rely on private actors to carry out their functions, such as Medicaid and Medicare, as well as the Section 8 housing program, in which the federal government pays a portion of the rent of qualifying low-income tenants to private landlords. These courts have, understandably, virtually ignored the public function test. ${ }^{311}$ As for the nexus test, the lower courts have distinguished Blum and Rendell-Baker by focusing on the level of discretion afforded the private decision-maker by the legislature. Where the discretion of the private decision-maker is constrained by substantive statutory or regulatory standards, the lowver courts have generally found state action. This door was implicitly left open in Blum by its emphasis on the role of the independent judgment of the nursing home physicians, ${ }^{312}$ and expressly left open in Rendell-Baker, where the Court indicated that if the local

309. Id. at 397.

310. This assumption has been questioned. See Chemerinsky, supra note 270, at 510-11.

311. Even under an expansive view of the public function doctrine, it is unlikely that the provision of welfare benefits would be considered a public function given this country's long history of mixed public and private poor relief efforts. See supra Part 11.A. Of course, part of the problem with the public function test is a definitional one, i.e, how narrowly or broadly one defines the function at issue. Arguably, the provision of government-funded public assistance has been, and is, undertaken only by the government. Yet such a narrow definition is unlikely to sway the Court. Rather, the Court refuses to acknowledge a public function unless it is one required by federal or state law or constitution. See, e.g., Am. Mfrs. Mut. Ins. Co. v. Sullivan, 526 U.S. 40, $55-57$ (1999) (discussed supra in Part IV.B.3).

312. See supra note 277 and accompanying text. 
regulations governing school personnel were more specific, state action might have been found. ${ }^{313}$

Grijalva v. Shalala represents this approach. ${ }^{314}$ There, the plaintiffs, a class of Medicare beneficiaries enrolled in HMOs, sued the Secretary of Health and Human Services (HHS) for failing to monitor denials of medical services by HMOs and for failing to enforce due process protections. Specifically, the plaintiffs asserted that the HMOs denied them medical services with inadequate notice of the basis for the denials, in violation of the Medicare Act's procedural protections. HHS countered that the decisions by the HMOs did not constitute state action and, thus, could not be attributed to HHS. The court disagreed, holding that the HMOs were state actors. ${ }^{315}$

The court reasoned that HMOs and the federal government "are essentially engaged as joint participants to provide Medicare services such that the actions of HMOs in denying medical services to Medicare beneficiaries ... may fairly be attributed to the federal government." 316 The court pointed to the government's extensive regulation of the HMOs and the fact that the "federal government has created the legal framework - the standards and enforcement mechanisms - within which HMOs make adverse determinations, issue notices, and guarantee appeal rights. ${ }^{\text {"317 }}$ Moreover, the statute provided that Medicare beneficiaries enrolled in HMOs could appeal adverse decisions to the Secretary of HHS who had the power to reverse the HMOs decision. The court expressly distinguished Blum, explaining that the decisions at issue in that case hinged on the independent medical judgments of private doctors and could not be approved or disapproved by state officials. ${ }^{318}$ Rather, the state officials could only alter the level of Medicaid benefits in response to the doctors' assessments. By contrast, in Grijalva, the court determined that the HMOs were making decisions as a governmental proxy pursuant to congressional and administrative mandates. ${ }^{319}$ Thus, the HMO decisions in Grijvala were more akin to coverage decisions or interpretations of the Medicare statute, rather than purely medical judgments. The court admonished that the government could not "avoid the due process requirements of the Constitution merely by delegating its duty to determine Medicare coverage to private entities." ${ }^{320}$

\footnotetext{
313. 457 U.S. $830,841-42$ (1982).

314. 152 F.3d 1115 (9th Cir. 1998), vacated by 526 U.S. 1096 (1999), remanded to 185 F.3d 1075 (9th Cir. 1999).

315. Id. at 1120 .

316. Id.

317. Id.

318. Id.

319. Id.

320. Id. at 1121 (citations omitted).
} 
Grijalva gets the state action analysis right. To begin with, the government was not held liable for actions outside of its control; indeed, HHS had direct responsibility for ensuring that HMOs followed the law. Moreover, concern over the individual freedom of the HMOs was misplaced; once they agreed to accept Medicare payments, they subjected themselves to strict regulatory controls as part of the deal. They thus voluntarily gave up any claim to individual freedom. Grijalva also properly placed liability on a culpable party, HHS. Importantly, Grijalva merged the standard for finding state action with the standard for establishing an entitlement; both emphasize the constraints on the discretion of decision-makers. The logical extension of this emphasis on discretion is that where an entitlement is at stake, a finding of state action should follow. In other words, because an entitlement is created by a rule-based legal scheme, it is hard to see how a private person can strip that entitlement away without becoming a state actor. After all, that actor is constrained by the same rules. The incongruous result of the Supreme Court's approach is a decision like Blum, in which an acknowledged entitlement (Medicaid) was stripped away by a private actor, who, as the dissent pointed out, was bound by detailed regulatory provisions. ${ }^{321}$ Grijalva suggests that it is entirely reasonable that the nexus inquiry include consideration of the type of interest at stake. That is, where an entitlement is at issue, the presumption should be that anyone affecting the status of that entitlement is a state actor. As Grijalva demonstrates, such a result is consistent with the underlying purposes of the state action doctrine.

Despite the logic and consistency of the Grijalva approach, it is questionable whether it will carry the day. Indeed, Blum implicitly rejected such an approach by holding that an entitlement can be lawfully stripped away by the discretionary decision of a private entity. As a result, and much to the surprise of many lawyers and laypersons alike, the entitlement status of a piece of property does not necessarily travel with the property. Notably, the Supreme Court reversed and remanded the Ninth Circuit's decision in Grijalva for review in light of American Manufacturers and certain statutory changes. ${ }^{322}$ Thus, the search for accountability over private welfare providers may well have to continue elsewhere.

\section{The Problem of Qualified Immunity for State Actors}

Even if a welfare beneficiary can establish that TANF benefits retain their entitlement status and that the private provider is a state actor, there

321. Blum v. Yaretsky, 457 U.S. 991, 1019-28 (1982) (Brennan, J., dissenting). This is not to say that the private doctor should have been personally liable for his decision. Rather, as noted supra, it was the state-created procedures which were unfair, and liablility should thus have fallen on the state.

322. 526 U.S. 1096 (1999). The Ninth Circuit remanded the case to the district court on September 1, 1999. 185 F.3d 1075 (9th Cir. 1999). 
remains the issue whether the private provider can claim qualified immunity from suit. In Section 1983 cases, qualified immunity protects government officials against liability from damages "insofar as their conduct does not violate clearly established statutory or constitutional rights of which a reasonable person would have known." ${ }^{\prime 323}$ Because the immunity issue is implicated only in damages cases, it does not pose a barrier to suits for structural and injunctive relief; $; 24$ thus, qualified immunity may have limited bearing on most constitutional litigation under the PRA.

Qualified immunity was designed to protect individuals from constitutional violations while ensuring that fear of damage liability does not deter government officials from performing their duties. ${ }^{325}$ For example, in a due process welfare case, a challenged official might base a claim of immunity on the uncertain entitlement status of TANF benefits. The official could argue that, as a result of this uncertainty, a failure to provide Goldberg-level process does not violate clearly settled law. ${ }^{326}$ However, current Supreme Court doctrine makes it unlikely that private welfare providers will be able to claim qualified immunity for any constitutional or statutory violations.

In Richardson v. McKnight, ${ }^{327}$ the Court held that prison guards employed by a private prison contractor are not entitled to qualified immunity in prisoner Section 1983 suits. The Court rejected a functional approach, and instead looked primarily to history and policy to gnide its analysis. After finding no historical tradition of immunity for private prison guards, ${ }^{328}$ the Court concluded that qualified immunity was not needed to deter timid decision making because marketplace pressures would ensure that private guards perform their job vigorously. ${ }^{329}$ The Court thus looked at the underlying purposes of the immunity and found that granting immunity to private prison guards did not further those purposes. The Court limited its holding in Richardson to cases "in which a private firm, systematically organized to assume a major lengthy administrative task

323. Harlow v. Fitzgerald, 457 U.S. 800, 818 (1982).

324. See, e.g., Am. Fire, Theft \& Collision Managers, Inc. v. Gillespie, 932 F.2d 816, 818 (9th Cir. 1991).

325. Wyatt v. Cole, 504 U.S. 158, 167 (1992).

326. Of course, one possible rejoinder to this argument would be that the flawed process violates the clear terms of the federal statute, which mandates that State plans "set forth objective criteria for the delivery of benefits and the determination of eligibility and for fair and equitable treatment, including an explanation of how the State will provide opportunities for recipients who have been adversely affected to be heard in a State administrative or appeal process." Pub. L. No. 104-193, $\S$ 402(a)(1)(B)(iii), 110 Stat. 2105, 2114 (1996) (codified at 42 U.S.C. $\S 602(a)(1)(B)(i i i))$.

327. 521 U.S. 399 (1997).

328. Id. at $405-07$.

329. Id. at 409 . By contrast, the dissent contended that immunity should be determined on the basis of the public function being performed. Id. at $4 \mathrm{I} 6$ (Scalia, J., dissenting). However, Justice Scalia would likely reject a public function analysis on the threshold state action question, making his immunity analysis irrelevant in most cases. 
(managing an institution) with limited direct supervision by the government, undertakes that task for profit and potentially in competition with other firms." ${ }^{330}$ The Court's limited holding appears to encompass most welfare contracting schemes because the private welfare providers assume the major administrative task of putting the poor to work, and they do so for profit and with only overall monitoring by their government contracting partners. Even nonprofit organizations might be included in the Court's holding because they compete for contracts with other nongovernmental welfare providers. ${ }^{331}$ Accordingly, once a welfare beneficiary jumps over the difficult due process and state action hurdles, the immunity issue will present little cause for concern. ${ }^{332}$

\section{$\mathrm{V}$}

\section{Alternatives to Constitutional Litigation}

Given the Court's current narrow reading of the state action doctrine, the need for alternatives to constitutional litigation to enforce accountability in privatized welfare jurisdictions is apparent. ${ }^{333}$ These potential alternatives include statutory, contractual, and equitable claims. In fact, the latter two types of claims are available only in privatized jurisdictions; they have only a limited role in enforcing accountability against governmental entities. Yet, as explained below, each of these alternatives retains significant limitations. At present, in a privatized welfare jurisdiction, there is simply no reliable, unified theory for enforcing procedural norms. Just as the welfare system has been decentralized and devolved, so will be the law that governs it.

\section{A. Statutory Causes of Action}

The federal and state statutes governing TANF programs are potential sources of procedural rights for welfare beneficiaries. These statutes generally provide some notice and hearing requirements, even though some of those requirements arguably fall short of constitutional due process nornis. However, these statutory requirements are not necessarily enforceable. Where statutes do not expressly provide for private enforcement, the $\mathrm{Su}-$ preme Court and the state courts have placed tight limits on their

330. Id. at 413. By contrast, the court excluded from its holding cases that "involve a private individual briefly associated with a government body, serving as an adjunct to government in an essential governmental activity, or acting under close official supervision." Id. None of these situations appear to apply to the welfare contracting context.

331. E.g., Halvorsen v. Baird, 146 F.3d 680, 686 (9th Cir. 1998).

332. The Court in Richardson left open the issue whether the private prison guards could assert some sort of "good faith" defense. 521 U.S. at 414. Thus, this type of defense could arise in future Section 1983 privatization lawsuits.

333. Exploration of these alternatives may also prove essential in any jurisdiction which denies entitlement status to TANF benefits and where the state action question is thus irrelevant. 
enforceability. Moreover, courts are more likely to limit enforceability of rights asserted against private, rather than governmental, parties.

At the state level, other mechanisms for enforcing procedural rights include claims under state administrative procedure acts and statutory mandamus claims (which are sometimes alternatively founded in common law). Both of these types of claims are used to force government officials to comply with statutory duties. Yet it is not clear that they would be effective against private entities. This Part discusses how privatization affects the availability of various statutory theories for enforcing due process norms.

\section{Federal Enforcement Mechanisms \\ a. The TANF Enforcement Scheme}

Congress did not completely ignore the procedural rights of TANF recipients. To be eligible for TANF funds, each state must submit a plan to HHS outlining its family assistance program. ${ }^{334}$ As part of its plan, a state must "set forth objective criteria for the delivery of benefits and the determination of eligibility and for fair and equitable treatment, including an explanation of how the State will provide opportunities for recipients who have been adversely affected to be heard in a State administrative or appeal process. ${ }^{\prime 335}$ However, TANF does not provide any express private right to enforce this provision.

Federal government enforcement of TANF rights is also extremely limited. The statute provides that the federal government can enforce the statute only where expressly permitted. ${ }^{336}$ The federal government's sole enforcement mechanism is to reduce grants to states that fail to comply with certain, defined statutory requirements. ${ }^{337}$ However, failure to adhere

334. The Personal Responsibility Act of 1996, Pub. L. No. 104-193, § 402, 101 Stat. 2105, 2113 (codified at 42 U.S.C. $\S 602(a)$ ), sets forth the criteria that must be addressed in the state plan.

335. See $\S 402(a)(1)(B)(i i i)$ (codified at 42 U.S.C. $\S 602(a)(1)(B)(i i i)$ ). In the legislative history, the House reported that while it was

granting flexibility to States to operate block grant programs, it is determined that the delivery of benefits for needy families is provided for in a fair and equitable manner. Consequently, Statcs must establish as part of their State plan that determinations of eligibility, and the provision of benefits, will be conducted according to these standards.

H.R. REP. No. 104-651, at 1330 (1996), reprinted in 1996 U.S.C.C.A.N. 2183, 2389.

336. $\S 417$ (codified at 42 U.S.C. $\$ 617$ ) ("No officer or employee of the Federal Government may regulate the conduct of States under this part or enforce any provision of this part, except to the extent expressly provided in this part."). This limits the scope of HHS' regulatory authority. See MARK Greenberg \& Steve Savner, Ctr. for law and Soc. Policy, A Detailed Summary of Key Provisions of the Temporary Assistance for Needy Families Block Grant of H.R. 3734, at 46 (1996) ("Section 417 does not prevent HHS from saying what the agency thinks the law means, but HHS' interpretation will not be binding on a State except where expressly authorized, and it is unclear how much a court would defer to HHS' interpretation.").

337. Section 409 , codified at 42 U.S.C. $\$ 609$, sets forth fourteen instances in which a State's grant may be reduced, ranging from misexpenditure of TANF funds to failure to comply with the five-year limit on assistance. No grant can be reduced by more than twenty-five percent. Id. $\S 409$ (d). The Act 
to Section 402 does not expressly trigger a penalty. ${ }^{338}$ At most, under current HHS interpretations of the statute, a state that denies due process before sanctioning TANF recipients for failure to work could face a reduction in the amount of its grant, and presumably the states would be held accountable for violations committed by private welfare agencies.

But this penalty structure provides no remedy to individual TANF recipients who are improperly sanctioned. Nor does it ensure fair procedures for individuals facing adverse action by a welfare provider outside of the sanction-for-failure-to-work context, such as denials of eligibility.

\section{b. Section 1983 Statutory Enforcement}

Accordingly, the lack of express private remedies in the Act and the limited scope of federal enforcement raise the issue whether Section 402 of the Act creates any implied remedies, either through the statute itself or through Section 1983. When plaintiffs seek to enforce federal statutes against state actors, Section 1983 is available as a vehicle for enforcement. ${ }^{339}$ In Section 1983 cases, it is presumed that Congress intends to allow private enforcement of federal statutes. Accordingly, to defeat a Section 1983 statutory cause of action, the defendant bears the burden of showing that Congress affirmatively intended to foreclose Section 1983 enforcement. ${ }^{340}$

The Court requires the presence of three factors to show that a particular statutory provision gives rise to a federal right enforceable under Section $1983:{ }^{341}$ (1) Congress has intended that the provision in question

also provides bonuses for certain state achievements such as reducing out-of-wedlock births and "high performance." Id. $\$ 403$ (codified at 42 U.S.C. $\$ 603$ ).

338. The statute allows for penalties to be assessed against states who fail to sanction non-working adults. Id. $\$ 409(\mathrm{a})(14)$ (codified at 42 U.S.C. $\$ 609(\mathrm{a})(14))$. In turn, HHS has interpreted this penalty provision to "appl[y] both to a State's failure to sanction when it should have and to its imposition of a sanction when it should not have imposed one." 64 Fed. Reg. 17,793 (Apr. 12, 1999). In determining the extent of a penalty, HHS has stated that it will look at whether the state has established a control mechanism to ensure that grants are appropriately reduced. This control mechanism "should ensure that recipients are informed of their rights to fair hearings and advised of the process for invoking that right." 64 Fed. Reg. 17,794 (Apr. I2, 1999).

339. Maine v. Thiboutot, 448 U.S. I, 4 (1980) (holding that a Section 1983 remedy is available to vindicate rights secured by federal laws). As noted supra note 260, Section 1983 provides for vindication of "right[s] . . . secured by the Constitution and laws." Rev. Stat. $\$ 1979,42$ U.S.C. $\$$ I 983 (1996).

340. Golden State Transit Corp. v. City of Los Angeles, 493 U.S. 103, 107 (1989).

341. Even if the statute creates enforceable remedies, Section 1983 is not available if the statute contains a comprehensive enforcement scheme evidencing congressional intent to preclude Section 1983 enforcement. Middlesex County Sewerage Auth. v. Nat'l Sea Clammers Ass'n, 453 U.S. 1, 20 (1981). This exception is not a concern in the context of the PRA because the PRA provides for no enforcement by private parties and for only limited enforcement by the federal government. See supra text accompanying notes 332-336. The Court has only found remedial schemes sufficient to displace Section 1983 twice. In Sea Clammers, the Court held that the "unusually elaborate enforcement provisions" of the Federal Water Pollution Control Act, 33 U.S.C. $\$ 1251$, evidenced congressional intent to foreclose Section 1983 because the statute granted the Environmental Protection Agency 
benefit the plaintiff; (2) the right is not so vague and amorphous that its enforcement would strain judicial competence; and (3) the statute unambiguously imposes a binding obligation on the states by using mandatory rather than precatory language. ${ }^{342}$ Valid arguments can be made that Section 402 satisfies these prongs; however, because the procedural protections in TANF are far less specific and detailed than those in other federal public welfare statutes, success under such a theory may be elusive. ${ }^{343}$

As to the first factor, the courts have long held that procedural protections in public welfare statutes are intended to benefit the beneficiaries of those statutes. ${ }^{344}$ Indeed, it is difficult to see any other reason for such requirements. As to the second factor, the rights enumerated in Section 402(a)(1)(B)(iii) of the PRA are not further defined in either the statute or the regulations (and HHS likely lacks the authority to delineate these rights). Nevertheless, the right to notice and a fair hearing is not so vague and amorphous that its enforcement would "strain judicial competence." To the contrary, the judiciary has special competence in defining the content of due process mechanisms as it is largely responsible for the development and enforcement of those norms.

The third prong of the test poses the greatest challenge. The PRA speaks in mandatory terms: the state "shall set forth objective criteria for the delivery of benefits and the determination of eligibility and for fair and equitable treatment....3345 Arguably, however, this language merely requires states to write "objective criteria" into their plans, and not necessarily to implement those criteria. After the Court's decision in Suter v. Artist $M$., in which the Court held that a private plaintiff could not enforce a state plan requirement, ${ }^{346}$ it has been hotly contested whether State plan

enforcement power through the use of noncompliance orders, civil suits, and criminal penalties and included two citizen-suit provisions. Id. at 13. Likewise, in Smith v. Robinson, 468 U.S. 992, 1010-11 (1984), the Court held that the Education of the Handicapped Act, 20 U.S.C. $\$ 1400$ et seq., precluded a Section 1983 remedy bccause it contained a "carefully tailored administrative and judicial mechanism," that included local administrative review that culminated in a right to judicial review. Id. at 1009, 100911. The Court rcasoned that allowing parents to skip the administrative procedures by going straight to court would have "render[ed] superfluous most of the detailed procedural protections outlined in the statute." Id. at 1011.

342. See Blessing v. Freestone, 520 U.S. 329, 340-41 (1997).

343. Compare Pub. L. No. 104-193, $\$ 402,110$ Stat. 2105, 2113 (1996) (codified at 42 U.S.C. $\$$ 601 ), with Food Stamp Act, 7 U.S.C. $\$ 2011$ and the regulations promulgated thereunder at 7 C.F.R. $\$$ 273; and Medicaid program, 42 U.S.C. $\$ 1396$ and the regulations promulgated thereunder at 42 C.F.R. $\S 431$.

344. See, e.g., Meacham v. Wing, 77 F. Supp. 2d 431, 438-40 (S.D.N.Y. 1999) (analyzing Food Stamp Act and Medicaid Act).

345. $\$ 402(a)(1)(B)(i i i)$ (codificd at 42 U.S.C. $\$ 602(a)(1)(B)(i i i)$ ) (emphasis added).

346. 503 U.S. 347 (1992). In Suter, the Court held that the Adoption Assistance and Child Welfare Act of 1980's requirement that "rcasonable efforts" be made to prevent removal of children from their homes was unenforceable. Id. at 363 . The Court reasoned, in part, that the state had a plan providing that "reasonable efforts" would be made, and that there was no concommitant duty to actually exercise those reasonable efforts. Id. at 358-62. The Court also held that the "reasonable efforts" language gave 
requirements entitle beneficiaries to the actual rights enumerated in the state plan. Courts have split on this issue. ${ }^{347}$ Accordingly, Section 1983 challenges to violations under state plans that contam unfair or inadequate procedural protections may fare better than challenges to procedural violations committed under otherwise conforming plans. ${ }^{348}$

\section{c. Implied Right of Action}

Where a case does not involve state action, plaintiffs cannot rely on Section 1983 and they must establisl that the statute creates an implied right of action. ${ }^{349}$ To establish an implied right of action, the plaintiff bears the burden of showing that Congress intended to create an enforceable private right when it enacted the relevant statute. ${ }^{350}$ The opposite presumptions for section 1983 statutory actions and implied rights of action generally make it easier to establish a Section 1983 cause of action than an implied right of action. ${ }^{351}$ One legal effect of privatization, then, is that because of the restrictive nature of the Court's current state action doctrine, beneficiaries of social welfare programs in privatized jurisdictions may have a harder time enforcing federal statutes than those in public jurisdictions.

A TANF beneficiary pursuing an implied right of action is likely to fail. Under the Court's current implied right of action analysis, the "most important inquiry ... is whether Congress intended to create the private

states discretion to determine how they would comply with the language such that the clause did not create enforceable rights. Id. at 360 .

347. The subsequent debate among the circuit courts over whether plaintiffs can challenge actions in violation of otherwise valid state plans in these types of circumstances is discussed in Harris $\boldsymbol{v}$. James, 127 F.3d 993, 1002-03 (11th Cir. 1997) (holding that there is no federal right enforceable through Section 1983 for transportation to and from Medicaid providers). Some courts have decided that the substance of a state plan requirement is enforceable if it is specific. Id. Under this approach, a requirement that a state plan include provision for fair hearings would be more enforceable than a requirement (such as in Suter) that a state plan include "reasonable efforts" to meet a goal. This is beeause the former is less open to the exercise of discretion than the latter.

348. Assuming the three prongs of the Section 1983 statutory enforcement test are satisfied, a plaintiff could easily surmount the exception to enforcement for statutes that indicate affirmative congressional intent to preclude Section 1983 enforcement. The lack of a comprehensive enforcement scheme in the PRA, see supra notes 336-338 and accompanying text, means that individual enforcement is not incompatible with the statute. But it also suggests that Congress did not contemplate private enforceinent.

349. If a statute expressiy provides for private enforcement, then the plaintiff can bring a suit directly under the statute without relying on either Section 1983 or the implied right of action doctrine. PRA does not provide for private enforcement.

350. See Susan J. Stabile, The Role of Congressional Intent in Determining the Existence of Implied Rights of Action, 8I NOTRE DAME L. REV. 861, 872 (1996). The leading case explaining this difference is Samuels v. District of Columbia, 770 F.2d 184 (D.C. Cir. 1985); see also Chan v. City of New York, 1 F.3d 96, 103 (2d Cir. 1993).

351. Section 1983 was regularly used as a vehicle to enforce various AFDC provisions. E.g., Albiston v. Me. Comm'r of Human Servs., 7 F.3d 258 (1st Cir. 1999); Howe v. Ellenbecker, 8 F.3d 1258 (8th Cir. 1993). 
remedy sought by the plaintiffs." 352 Intent can be divined through statutory language, legislative history, and statutory structure. ${ }^{353}$ Here, courts are unlikely to conclude that Congress "intended" the statute to be enforced at all, except perhaps to penalize states that give benefits to undeserving individuals. ${ }^{354}$ First, Congress attempted to strip away the entitlement status of welfare benefits. ${ }^{355}$ Second, Congress gave no significant enforcement mechanisms in any portion of the statute. ${ }^{356}$ Not surprisingly, the implied right of action theory has been of little assistance in recent years to beneficiaries of public programs. ${ }^{357}$ Simply put, it is hard to divine intent from congressional silence. ${ }^{358}$

352. Suter v. Artist M., 503 U.S. 347, 364 (1992). This analysis is derived from the four-part test of Cort v. Ash, 422 U.S. 66 (1975), which has never been overruled, but which has essentially been boiled down to an intent inquiry. The Cort factors ask (1) whether plaintiff is within the class for whose benefit the statute was enacted; (2) whether the legislative intent shows a desire to either create or deny a remedy; (3) whether implying a remedy is consistent with the statute's purposes; and (4) whether the cause of action is one traditionally relegated to state law such that it would be inappropriate to infer a federal cause of action. Id. at 78. For the development of the legislative intent test, see generally H. Miles Foy, IIl, Some Reflections on Legislation, Adjudication, and Implied Private Actions in the State and Federal Courts, 71 Cornell L. Rev. 50I, 562-66 (1986); Stabile, supra note 350.

353. Specific factors that courts have considered include: whether the statute grants exclusive enforeement jurisdiction to a regulatory agency; whether the statute contains an elaborate and comprehensive remedial scheme; whether the legislative history indicates that Congress expected federal courts to be active in creating federal common law under the statute; whether Congress explicitly created or denied a cause of action or remedy in a related context; whether the statute explicitly confers a right directly upon a particular class of persons, whether a private right of action effectuates Congress's goals in enacting the statute; and whether the private right of action is consistent with Congress's purpose. See generally Stabile, supra note 346.

354. The implied right of action doctrine has narrowed dramatically since Rosado v. Wyman, 397 U.S. 397 (1970), in which the Court held that New York welfare recipients could challenge the validity of a New York welfare statute that conflicted with AFDC requirements. The Court reasoned that

We are most reluctant to assume Congress has closed the avenue of effective judicial review to those individuals most directly affected by the administration of its program.... It is ... peculiarly part of the duty of this tribunal, no less in the welfare fleld than in other areas of the law, to rcsolve disputes as to whether federal funds allocated to the States are being expended in consonance with the conditions that Congress has attached to their use.

Id. at 420-23.

355. See supra note 235 and accompanying text.

356. The only penalties facing non-complying states are found in Pub. L. No. 104-193, $\$ 409,110$ Stat. 2105, 2142 (1996) (codifled at 42 U.S.C. $\S 609$ ), and none of those penalties are triggered by failure to enforce due process norms. See supra Part V.A.l.a-b.

357. See generally Pauline E. Calande, State Incorporation of Federal Law: A Response to the Demise of Implied Federal Rights of Action, 94 YALE L.J. 1144, 1145 (1985); Foy, supra note 352; Stephen E. Ronfeldt, Implying Rights of Action for Minorities and the Poor Through Presumptions of Legislative Intent, 34 Hastings L.J. 969 (1983). Foy explains how, in the twentieth century, courts shifted from implying a remedy for every legal wrong to a view that "the adjudicatory consequences of legislation depended upon demonstrable legislative purposes and intentions." Foy, supra note 352, at 548.

358. See Calande, supra note 357, at 1145. As H. Miles Foy explains:

If the controlling consideration was whether Congress had affirmatively intended to create a private remedy, then the implied remedy ceased to be a remedy that was implied in law. It became, instcad, a remedy that was implied in the legislative facts. It rested upon affirmative 


\section{d. Conclusion}

In brief, while it is conceptually easier to argue for Section 1983 enforcement of Section 402 than for an implied right of action under the statute, the PRA's unique structure makes either argument tenuous at best. If anything can be said of Congress's intent, it is that the states have discretion im fashioning their own procedural protections. Thus, we can agam see how the grant of discretion in the administration of public benefits programs lessens beneficiaries' procedural rights, particularly im privatized jurisdictions. An increase in discretion lessens the likelihood that a benefit will obtam entitlement status; lessens the likelihood that a private actor administering the benefit will be deemed a state actor; and lessens the ability of plaintiffs to enforce underlying statutes through either Section 1983 or an implied right of action theory. Unfortunately then, an increase in discretion results in fewer protections for beneficiaries precisely when more are needed. Accordingly, under the PRA, plaintiffs will likely need to turn to state-granted procedural protections.

\section{State Enforcement Mechanisms}

As a result of the block grant approach, a better source of procedural protections for TANF beneficiaries may lie in state law. Congress expressly requested that states devise their own due process schemes for TANF benefits. Although most states have retained the same generous notice and hearing procedures that were available under AFDC, there is evidence from several jurisdictions that welfare agencies are not complying with those procedures. ${ }^{359}$ Thus, in many cases, relief outside the scope of the administrative review process is required. However, enforcing these state provisions may prove to be as frustrating as enforcing the federal requirement. Thus, just as TANF devolved discretion downward to the states, it also is likely to herald the growth of state court welfare litigation based on state laws, and the result will be a patchwork of procedural protections among the states.

\section{a. State Implied Rights of Action}

There is no analog to Section 1983 in the state courts. Therefore, absent any express statutory causes of action, plaintiffs must argue that they have an implied private right of action to enforce favorable state procedural protections. ${ }^{360}$ Unlike the federal courts, the states historically developed

legislative intentions that Congress had somehow failed to express in the legislative text.

Absent affirmative intentions, express or implied, the private remedy simply did not exist. Foy, supra note 352 , at 565 .

359. See supra notes $254-256$ and accompanying text.

360. For instance, in Wisconsin, there is an express right of action to enforce the nondiscrimination provisions of the state's welfare contracting program with religious entities. Wis. 
the implied right of action theory in the context of tort law. That is, the states have long held that the violation of legislative rules, particularly penal ones, can constitute negligence per se. ${ }^{361}$ Theoretically, under this approach, a welfare recipient who is wrongly sanctioned or cut off from TANF benefits could sue their welfare provider under a negligence theory for any resulting personal injuries. As the Giuliani litigation makes clear, the injuries that flow from unfair procedures can be severe, including emotional distress, hunger, loss of housing, injuries sustained from lack of medical attention, and the like.

Yet states have difficulty applying a negligence per se theory in cases that do not fit the mold of a traditional personal injury action. ${ }^{362}$ In addition, several states appear to be drifting toward the Supreme Court's view of implied rights of action. That is, state courts are increasingly focusing on legislative intent, which they divine through an analysis of language, legislative history, statutory purpose, and alternative remedies. ${ }^{363}$ The exact balance of these factors varies from state to state, and state law in this area is extremely hard to characterize. However, a focus on legislative intent is likely to have the same impact as the federal doctrine, where implied rights of action are few and far between.

\section{b. State APA Enforcement}

Typically in public benefits litigation, the shortcomings of the implied right of action doctrine have been compensated for by the availability of

Stat. ANN. $\S 49.114(8)$ (West 2000). But there is no comparable provision with regard to the other aspects of the Wisconsin Works program.

361. RestatemENT (SECOND) OF ToRTS $\$ 285$ (1965) provides:

The standard of conduct of a reasonable man may be (a) established by a legislative enactment or administrative regulation which so provides, or (b) adopted by the court from a legislative enactment or an administrative regulation which does not so provide, or (c) established by judicial decision, or (d) applied to the facts of the case by the trial judge or the jury, if there is no such enactment, regulation, or decision.

362. Foy, supra note 352, at 567-68. For instance, in Guibault v. Pima County, 778 P.2d 1342, 1344 (Ariz. Ct. App. 1989), the court held that an indigent person had no private right of action against a county agency for damages resulting from the alleged wrongful denial of the patient's application for medical assistance. The court reasoned that "when the state creates rights against itself that were unknown at common law, it is free to define not only the extent of the obligation undertaken but also the remedy, if any, for its enforcement." Thus, the patient was limited by the statute to the recovery of benefits wrongfully withheld. Id. at 1346 .

363. See, e.g., Murthy v. N. Sinha Corp., 644 So.2d 983, 985 (Fla. 1994) ("[L]egislative intent ... should be the primary factor considered by a court in determining whether a cause of action exists when a statute does not expressly provide for one."). Simiilarly, the court in Kranzush v. Badger State Mut. Cas. Co., 307 N.W.2d 256, 266 (Wis. 1981) stated

'The legislative intent to grant or withhold a private right of action for the violation of a statute ... is determined primarily from the form or language of the statute. The nature of the evil sought to be remedied, and the purpose it was intended to accomplish, may also be taken into consideration. In this respect, the general rule is that a statute which does not purport to establish a civil liability, but merely makes provision to secure the safety or welfare of the public as an entity, is not subject to a construction establishing a civil liability.' (citations omitted). 
judicial review under federal and state Administrative Procedure Acts. These acts provide standing to statutory beneficiaries to enforce agency accountability. ${ }^{364}$ Although the federal APA does not liave much of a potential role in TANF litigation because federal agencies have very little to do witl TANF implementation, state APAs may provide valuable support for enforcing procedural norms in many public jurisdictions. For instance, the 1981 Revised Model State APA provides for public participation in state agency rulemaking and for private rights of action to enforce adherence to state rules and regulations. It also requires that agencies formulate regulatory standards. ${ }^{365}$ Along these lines, the states recognize the administrative law principle that an agency must adhere to its own regulations. ${ }^{366}$

However, this principle may play little role in privatized jurisdictions because APAs operate as constraints on governmental, rather than private, action. $^{367}$ The case law is replete with examples of quasi-governmental and private organizations who were deemed to fall outside of Administrative Procedure Act requirements because they were not "agencies." ${ }^{\text {"368 }}$ Moreover, local and municipal governments generally do not have counterparts to state APAs. ${ }^{369}$ Thus, where private entities have contracted with local governments, neither entity is likely to be subject to APA-type requirements. Accordingly, beneficiaries in privatized welfare jurisdictions inay be denied this avenue of relief otherwise available to their counterparts in public ivelfare jurisdictions. ${ }^{370}$

364. For federal law, see 5 U.S.C. $\$ 702$ ("A person suffering legal wrong because of agency action ... is entitled to judicial review thereof."); see also Japan Whaling Ass'n. v. Am. Cetacean Soc'y, 478 U.S. 221 \& n.4 (1986) (including cases cited therein). For model state law, see MODEL State Adinistrative Procedure Act $\$ \$$ 5-101 to 5-118, 15 U.L.A. 118-166 (2000).

365. Model State Administrative Procedure Act $\$ \S 2-104,3-104,3-10 \$, 5-106,15$ U.L.A. $29,37,43,125(2000)$.

366. In federal law, this is known as the Accardi doctrine from the case United States ex rel. Accardi v. Shaughnessy, 347 U.S. 260 (1954).

367. See Diller, supra note 59, at 1190.

368. See, e.g., Dorris v. Mo. Substance Abuse Counselors' Cert. Bd., Inc., 10 S.W.3d 557, 560-61 (Mo. Ct. App. 1999) (holding that a private substance abuse counselors' certification organization was not an agency under state APA); Ins. Premium Fin. Ass'n of N.Y. v. N.Y. State Dep't of Ins., 668 N.E.2d 399, 402-03 (N.Y. 1996) (finding that New York Automobile Insurance Plan, which consisted of private insurers who provided liability insurance for drivers otherwise unable to obtain it, was not an agency); League Gen. Ins. Co. v. Catastrophic Claims Ass'n, 458 N.W.2d 632, 635 (Mich. 1990) (holding that an unincorporated, nonprofit association of private insurers was not an agency under state's APA); Graham v. Baker, 447 N.W.2d 397, 399 (Iowa 1989) (holding that a nonprofit organization which contracted with state to perform farm mediation services was not an agency). But cf. Bruggeman v. S.D. Chem. Dependency Counselor Cert. Bd., 571 N.W.2d 851, 853 (S.D. 1997) (holding that a nonprofit certification board was agency where state APA defined "agency"as including an "agent of the state vested with the authority to exercise any portion of the state's sovereignty"); Meri-Weather, Inc. v. Freedom of Info. Comm'n, 2000 WL 351351 (Conn. Super. Ct. 2000) (holding that a nonprofit community economic development corporation was an agency because it was the alter ego of a public agency).

369. See Charles H. Koch, Administrative Law \& Practice $\$ 2.32$ (1987).

370. Accordingly, welfare advocates in privatized jurisdictions should look closely at whether governmental officials have played a role in any procedural wrongdoing, such as by failing to monitor 


\section{c. State Mandamus Claims}

Mandamus is another doctrine often used at the state level to compel government officials to comply with governing laws. It is used to "compel performance of statutory duties," 371 and it has been used successfully to force state officials to provide due process before taking adverse action. ${ }^{372}$ For instance, one court held that mandamus could be used to force a university to provide a due process hearing to a tenured professor before discharging him for cause. ${ }^{373}$

Unfortunately, TANF beneficiaries will mostly find the mandamus option unfruitful for several reasons. Mandamus is considered an "extraordinary" remedy, available only to enforce specific legal rights, and courts will not issue it where other adequate relief is available to the complaining party. ${ }^{374}$ Moreover, because it is used to enforce existing rights, it is not available to control the exercise of official discretion, ${ }^{375}$ and discretion is the cornerstone of the PRA. In addition, it is generally available only against government officials, although some courts will apply it against private entities where public interests are involved. ${ }^{376}$ Thus, while mandamus could potentially play a role in forcing private (and public) welfare officials to provide specific due process rights, it is a limited remedy that must satisfy many hurdles before it is imposed.

\section{d. Conclusion}

In sum, because TANF devolves authority over welfare to the states, advocates will need to focus on state laws to enforce procedural protections. However, state remedies traditionally used to constrain official discretion may prove ill-fitted for privatized schemes. Moreover, implying rights of action under the state TANF laws appears to be an uphill battle. Thus, while statutory remedies should be examined, they may prove elusive in many cases.

private providers. Moreover, where due process failures occur higher in the administrative appeals process, government officials are likely to be involved.

371. 52 AM. JuR. 2D Mandamus $\$ 4$ (1970).

372. See, e.g., Plymel v. Moore, 770 So.2d 242 (Fla. Dist. Ct. App. 2000) (granting mandamus to force Department of Corrections to provide due process protections to inmate accused of drug trafficking); Haas v. County of San Bernardino, 81 Cal Rptr. 2d 900 (1999) (granting writ of mandamus to force county officials to provide due process hearing before revoking license to operate massage clinic).

373. Gamer v. Mich. State Univ., 462 N.W.2d 832, 838 (Mich. Ct. App. 1990).

374. 52 AM. JuR. 2D Mandamus $\$ 31$ (1970).

375. Id. $\S 76$. However, mandamus can be used to force an official to exercise discretion. Id. $\S 77$.

376. See, e.g., State v. County Comm'n of Boone County, 452 S.E.2d 906, 919 (W. Va. 1994) (private nonprofit corporation was subject to mandamus because it elected to participate in state program and to reap the benefits of the program); Graham v. Baker, 447 N.W.2d 397, 400 (lowa 1989); Mobile Cmty. Action v. Hanke, 411 So.2d 783, 785 (Ala. 1982) ("A corporation may be compelled by mandamus to perform a specific duty imposed on it by law, because the corporation is the recipient of a franchise from the state ...."). 


\section{B. Contractual Claims}

Contract law provides a potentially more fertile avenue for relief, and, notably, one not available in government-run welfare programs. Welfare beneficiaries may be able to sue private providers under a third-party beneficiary theory to force compliance with the terms of the contract between the private welfare provider and the government entity. Of course, the desirability of suing for breach of contract hinges upon whether the terms of the contract are favorable for beneficiaries. To the degree that the terms are favorable, for example, by expressly requiring the private contractor to adhere to specified due process norms, beneficiaries in privatized jurisdictions may have an additional avenue to enforce their procedural rights. ${ }^{377}$

States have several incentives to include favorable terms in their contracts with private welfare providers. It makes sense for local governments to enter into contracts that permit private enforcement of TANF because they can reduce their own enforcement burden. Moreover, local governments can structure contracts so that the costs of noncompliance fall on the private contractors, either by requiring indemnification or by allowing direct suits against noncomplying private contractors. Yet whether local governments will seek such terms and be able to negotiate them will depend on a variety of factors, such as bargaining power, the political process, and procurement strategies, most of which are outside the control of beneficiaries.

The Restatement (Second) of Contracts $\S 302$ envisions two classes of third-party beneficiaries: intended and incidental. The former may enforce contracts; the latter may not. The distinction between the two hinges on the key question whether the contracting parties intended to benefit the alleged beneficiaries. ${ }^{378}$ Intent can be derived from "the circumstances surrounding the transaction as well as the actual language of the contract." ${ }^{379}$

In cases involving government contractors, the Restatement puts an additional gloss on the analysis. Given the potentially large size of the class of beneficiaries to a government contract, the Restatement (Second) of

377. See, e.g., DODENHOFF, supra note 61, at 21 (explaining that the welfare contracts in Milwaukee with private providers include sanctions for private agencies that fail to provide procedural due process); Office of Contracting and Procurement, District of Columbia, Job Placement AND Retention Services for Welfare Reform Request for Proposal (RFP), Solicitation No. JASC-CS-70090-01 (Jun. 28, 1999) (requiring the contractor, as part of the special contract requirements, to adhere to the Department of Human Services' grievance procedures).

378. A beneficiary is intended "if recognition of a right to performance... is appropriate to effectuate the intention of the parties ...." RESTATEMENT (SECOND) OF CONTRACTs \$ 302(1) (1981). In addition, an intended beneficiary must establish either that performance of the promise will satisfy a debt to the beneficiary or that the circumstances indicate that the promisee intends to benefit the beneficiary. Id. Despite the Restatement's emphasis on the intent of the promisee, courts have insisted on looking at the intent of both parties to the contract. See, e.g., Holbrook v. Pitt, 643 F.2d 1261, 1270 n.17 (7th Cir. 1981) (discussed infra this Part).

379. Restatement (Second) of Contracts $\$ 302 \mathrm{cmt}$ a (1981). 
Contracts $\S 313(2)$ presumes that a government contractor is not subject to consequential damages to a member of the public unless "the terms of the promise provide for such liability." $" 380$ As a result, those seeking damages for violation of public contracts must establish not only that the contracting parties intended to benefit them, but also that they intended to grant the beneficiaries the right to enforce the benefit. However, because this section expressly addresses only actions for consequential damages, it leaves the more general intent test of section 302 in place for third-party beneficiaries seeking injunctive or structural relief-far more common remedies in cases involving public programs. ${ }^{381}$

The third-party beneficiary theory has had some success in public housing cases, which also involve an interplay between government agencies, private contractors, and benefit recipients. ${ }^{382}$ For instance, in the leading case of Holbrook $v$. Pitt, ${ }^{383}$ Section 8 tenants alleged that they were denied benefits for several months without notice or hearings while their landlord delayed in sending in their Section 8 certification forms. The tenants claimed that they were third-party beneficiaries of the contracts executed between HUD and the private owners, and sought prompt implementation of the contracts and the receipt of retroactive benefits. ${ }^{384}$ The contracts provided that the owner was "responsible for determination of eligibility of applicants [for housing subsidies] ... and computation of the amount of housing assistance payments on behalf of each selected Family ...."385

380. A contractor could also be liable if "(b) the promisee is subject to liability to the member of the public for the damages and a direct action against the promisor is consistent with the terms of the contract and with the policy of the law authorizing the contract and prescribing remedies for its breach." Id. $\$ 313(2)$. In drafting these rules for government contractors, the Restatement recognized the rise in cases involving social service contracts, stating "recent cases have involved rights of poor people in federal-state social services agreements ...." Id. $\$ 313 \mathrm{cmt}$. a, note.

381. See Anthony Jon Waters, The Property in the Promise: A Study of the Third Party Beneficiary Rule, 98 HARv. L. REv. 1109, 1204 (1985). Waters argues that equitable restitutionary principles are much more appropriate for analyzing cases involving public programs. Id. at 1206-08. By contrast, all of the examples used in this section of the Restatement involve commercial transactions, such as contracts to carry mail, to maintain a certain water pressure at fire hydrants, to build a subway, and the like. See Restatement (SEcond) of Contracts $\$ 313 \mathrm{cmt}$. a (1981).

382. See e.g., Ayala v. Boston Hous. Auth., 536 N.E.2d 1082 (Mass. 1989) (Section 8 tenants wcre third-party beneficiaries of contracts between HUD and Boston Housing Authority as well as contracts between the Housing Authority and private landlords and could therefore recover damages flowing from housing authority's breach of obligations under contract to inspect for lead paint hazards); Holbrook v. Pitt, 643 F.2d 1261 (7th Cir. 1981); Hurt v. Phila. Hous. Auth., 806 F. Supp. 515 (E.D. Pa. 1992); Henry Horner Mothers Guild v. Chicago Hous. Auth., 780 F. Supp. 511 (N.D. 111. 1991); McNeill v. New York City Hous. Auth., 719 F. Supp. 233 (S.D.N.Y. 1989); Gonzalez v. St. Margaret's House Hous. Dev. Fund Corp., 620 F. Supp. 806 (S.D.N.Y. 1985). But see Reiner v. West Village Assocs., 768 F.2d 31 (2d Cir. 1985); Perry v. Hous. Auth. of Charleston, 664 F.2d 1210 (4th Cir. 1981).

383. 643 F.2d 1261 (7th Cir. 1981).

384. Id. at $1265-67$.

385. Id. at $1268 \mathrm{n} .13$ 
After consideration of both the statutory and regulatory provisions governing Section 8, as well as the terms of the contract, the court held that the tenants were third-party beneficiaries of this contract, reasoning that "[i]f the tenants are not the primary beneficiaries of a program designed to provide housing assistance payments to low income families, the legitimacy of the inulti-billion dollar Section 8 program is placed in grave doubt."386 The court went on to imply terms in the contract that required owners to certify tenants within a reasonable time after execution of contracts and that required HUD to pay the tenants retroactive benefits. ${ }^{387}$

Holbrook demonstrates how, in cases involving government contracts, the terms of the underlying statute play a role in interpreting the contract. ${ }^{388}$ Thus, the PRA's language requiring states to provide some procedural protections to claimants can potentially be quite helpful in these cases. The statute can be read as an overlay to the contract; that is, its terms are incorporated by the contract.

It should be noted that actual tenants, such as those in Holbrook, have had far greater success in pursuing a third-party beneficiary theory than apphicants for housing. ${ }^{389}$ This applicant/recipient divide likely reflects a concern with extending third-party beneficiary rights to a potentially vast

386. Id. at 1271 .

387. Id. at 1273-76. However, a Holbrook type theory is useless where the contractual language expressly prohibits third-party claims. See, e.g., Cobos v. Dona Ana County Hous. Auth., 908 P.2d 250, 255 (N.M. Ct. App. 1995) ("[T] he intent of the clause is clear, and our duty is to enforce the contract as written.").

388. See H. Miles Foy, III, Legislation and Pedagogy in Contracts 101, 44 ST. LouIs U. L.J. $1273,1280-81$ (2000). Foy explains that

In cases involving government contracts, various courts have suggested that the answer [to the 'intended beneficiary' question] may turn on the interpretation of the legislation that creates the contracting authority. If the legislation itself contains evidence of a legislative intention to benefit a certain class of people, then such people may be the intended beneficiaries' of contracts made pursuant to that legislation, and they may therefore be able to sue to enforce them.

389. Compare Holbrook v. Pitt, 643 F.2d 1261 (7th Cir. 1981) (finding that tenants are third-party beneficiaries of contracts between HUD and landlords holding HUD insured mortgages), with Price v, Pierce, 823 F.2d 1114, 1121 (7th Cir. 1987) (finding that prospective tenants were not third-party beneficiaries of contracts because "to give each applicant for subsidized housing the status of a party to the contract would make almost every lower-income person in the United States a potential plaintiff..."). But see Gomez v. Hous. Auth. of El Paso, 805 F. Supp. 1363 (W.D. Tex. 1992) (applicants can sue under third-party beneficiary theory).

Another distinction has arisen in the caselaw between tenants of Section 8 property and tenants living in properties with federally insured inortgages who then sue on the basis of the agreement between HUD and the property owner. The leading cases rejecting a third-party beneficiary theory are of the latter sort. See Reiner v. West Village Assocs., 768 F.2d 31 (2d Cir. 1985); Perry v. Hous. Auth. of Charleston, 664 F.2d 1210 (4th Cir. 1981); Angleton v. Pierce, 574 F. Supp. 719 (D.N.J. 1983). In these cases, the contracts between HUD and the developer are primarily loan documents that do not spell out rights for tenants. Accordingly, there are no terms within the contracts that benefit the tenants, and they do not provide a source for relief. As stated earlier, a contractual claim is only useful if there are beneficial contractual terms. 
number of persons. ${ }^{390}$ As one court cautioned in a public housing case, "so wide a net of liability could make developers reluctant to participate in the program."391 This concern seems overblown in cases involving public benefits programs because the underlying statutes define an identifiable class of beneficiaries. Moreover, these courts are conflating actual applicants with potential applicants, who would likely lack standing to bring suit in the first place.

This concern over vast numbers of plaintiffs in government contract cases is more appropriate in disputes involving commercial contracts, which are not so narrowly circumscribed. For instance, in the paradigm case of H.R. Moch Co. v. Rensselaer Water Co. ${ }^{392}$ a company providing fire hydrant services by contract with the city was sued by a private warehouse owner after the hydrant did not provide adequate water during a fire. Judge Cardozo held that the plaintiff was not an intended beneficiary of the contract, stating that "[a] promisor will not be deemed to have had in mind the assumption of a risk so overwhelming for any trivial reward." ${ }^{\prime 393}$ By contrast, the PRA identifies a specific class of persons-far sinaller than the general public - as potential recipients of TANF benefits, that is, needy families with children. Moreover, the policies articulated in the PRA einbody a congressional desire to make objective standards, fair hearings, and appeal procedures available to welfare recipients (even if Congress arguably did not want those procedures to rise to a constitutionally protected status). This public policy, along with the defined class of beneficiaries, cuts in favor of allowing welfare applicants to enforce contractual terms that embody or enact those policies. ${ }^{394}$

The third-party beneficiary theory holds great promise for TANF recipients in privatized jurisdictions. It makes sense that a contract theory should play a large role for enforcing accountability in a contracting scheme. Unfortunately, the usefulness of this theory lies outside the control of TANF claimants. To begin with, this approach only makes sense if the underlying contractual terms are beneficial to claimants. But since TANF claimants are not at the negotiating table, they are left at the mercy of the negotiating process. ${ }^{395}$ The problem becomes particularly acute when

390. See Melvin Aron Eisenberg, Third-Party Beneficiaries, 92 CoLum. L. REv. 1358, 1407 (1992).

391. Price v. Pierce, 823 F.2d 1114, 1121 (7th Cir. 1987).

392. 159 N.E. 896 (1928).

393. Id. at 898 . This is the first case cited in the second illustration of the RESTATEMENT (SECOND) of CONTRACTs $\S 313$ (1981).

394. Although the PRA is quite punitive in many respects, it clearly establishes a public policy of assisting the poor to become self-sustaining. Accordingly, any contractual breaches that undermine this policy should be fair game for legal attack.

395. Notably, state and local procurement laws are directed at preserving fairness in the bidding process and protecting the rights of bidders. They make scant provision for including contract 
powerful corporations such as Lockheed and Maximus are involved because they may be able to demand concessions from local governments that accrue to their own benefit. ${ }^{396}$ For example, a simple declaration in the contract that it is unenforceable by third-parties will render the contractual approach moot. It is unclear who, if anyone, will look out for the interests of the poor populations who rely on TANF. Thus, just as TANF recipients are largely at the mercy of the political process to grant them entitlements and due process rights, they are at the mercy of contracting parties to define and/or grant them contractual rights.

\section{Equitable Claims}

One component of due process is the right to accurate information. As the Giuliani litigation demonstrates, severe harms can flow from misinformation. Thus, when welfare beneficiaries rely on a welfare provider's misinformation to their detriment, either by failing to receive benefits to which they are entitled, or by obtaining benefits to which they are not lawfully entitled (and are then asked to repay), they may be able to assert a claim of equitable estoppel. Although estoppel claims are unlikely to be used to affirmatively seek structural, injunctive relief, an estoppel claim "creates a personal, situation-specific bar to an assertion of the truth, or to a claim or defense that is generally applicable and meritorious. ${ }^{.397}$ As a result, it has the potential to serve as a constraining mechanisin on welfare officials.

Normally, the government and its agents are granted substantial immunity from estoppel claims. For instance, in Schweiker v. Hansen, ${ }^{398}$ a front-line worker at a Social Security office erroneously told a claimant that she was ineligible for insurance benefits. When the claimant later discovered that she could apply for benefits, she sought benefits retroactive to the date of the misinformation. However, the Supreme Court held that the agency was not bound by the eniployee's statements and could deny the claim. The Court reasoned that to allow estoppel would put the Government " "at risk that every alleged failure by an agent to follow instructions to the last detail in one of a thousand cases"' would undermine the

beneficiaries in the contracting process, whether it be soliciting bids, selecting bids, or monitoring contracts. See Model Procurement Code for State and Local Governments (1979).

396. For instance, in a child support enforcement contract with California, Lockheed was able to limit its liability to $\$ 3$ million. Yet cost overruns that led to the contract's cancellation ran into the hundreds of millions of dollars. See supra note 8.

397. Joshua 1. Schwart, The Irresistible Force Meets the Immovable Object: Estoppel Remedies for an Agency's Violation of Its Own Regulations or Other Misconduct, 44 ADMIN. L. REV. 653, 661 (1992).

398. 450 U.S. 785 (1981). 
underlying regulations. ${ }^{399}$ As a result, courts allow estoppel to lie against the government only in extreme cases, such as those involving "affirmative misconduct" or where the injury to the private interest substantially outweighs the public interest. ${ }^{400}$ By contrast, estoppel is regularly awarded as a remedy against private parties. This suggests that estoppel claims may more easily be brought im privatized welfare jurisdictions against front-line workers who negligently or intentionally mislead claimants.

A word of warning is in order, however. The estoppel doctrine speaks in terms of agents and principals, not in terms of state action. Indeed, one reason given for governmental immunity from estoppel claims is a reluctance to make the government accountable for the unauthorized, or ultra vires, conduct of its agents. ${ }^{401}$ As a result, potentially complicated issues exist regarding whether a private welfare provider could avoid estoppel by claiming to be an agent of the government. Clearly, the incentives for a private welfare provider to assume the cloak of governmental status differ with the area of law. ${ }^{402}$ Where state action is concerned, private entities will stress their remoteness from government. Where estoppel is concerned, private entities will stress their interconnectedness with government. And the current state of law may well allow them to have their cake and eat it too.

399. Id. at 789-90 (quoting Schweiker v. Hansen, 619 F.2d 942, 956 (1980) (Friendly, J., dissenting). The reasons given for limiting estoppel of the government vary in the caselaw, and generally include one or more of the following:

(1) sovereign immunity; (2) the separation of powers theory, under which certain judicial determinations of government liability are inappropriate; (3) lack of reasonable reliance by the person seeking estoppel due to the limited scope of governmental agents' authority; (4) the greater weight given to public interests over private interests to be vindicated by estoppel; (5) the desire to limit potentially vast liability; (6) protection of the free dissemination of government information; and (7) the fear that an estoppel rule might be used by government agents acting in collusion with private parties to defraud the government.

Frederick S. Kuhlman, Comment, Government Estoppel: The Search for Constitutional Limits, 25 LOY. L.A. L. REv. 229, 229-30 (1991).

400. Schwartz, supra note 390 , at 665-66. Another notable exception at the state level to the general rule is Lentz v. McMahon, 777 P.2d 83 (Cal. 1989), in which the court held that a welfare recipient could assert estoppel as a defense in an administrative proceeding in which the government sought to recoup overpayments. The court stated, "estoppel against a welfare agency may be appropriate when ... a government agency has negligently or intentionally caused a claimant to fail to comply with a procedural precondition to eligibility, and the failure to invoke estoppel would cause great hardship to the claimant." Id. at 401-02.

401. Kuhlman, supra note 399 , at 243-47.

402. For instance, government contractors regularly attempt to claim sovereign immunity in products liability cases. See generally John F. Seymour, Liability of Government Contractors for Environmental Damage, 21 PuB. ConT. L.J. 491 (1992). The Supreme Court created a governmentcontractor defense for military contractors who comply with government specifications in Boyle $v$. United Techs. Corp., 487 U.S. 500 (1988). 


\section{CONCLUSION}

The Personal Responsibility Act dramatically reformed welfare administration. Welfare providers now do much more than check off boxes on forms and dispense checks. Rather, they engage in a wide variety of counseling tasks in order to carry out their mandate of putting people to work. This new approach results in both a lack of objective, measurable criteria to judge providers' performance, and an increase in the discretion of front-line workers. When privatization is added to the PRA's discretionary mix, accountability to welfare claimants attenuates. Further, although the government plays a role in defining and monitoring contract terms, the complexity of welfare provision after the PRA makes it difficult for governmental entities to ineasure private performance in a meaningful way. As a result, the actions of private welfare providers remain screened from view.

Accordingly, it is inore important than ever to locate enforceable legal rights for welfare beneficiaries. Unfortunately, as the preceding analysis of procedural protections demonstrates, privatization limits the availability of procedural protections. Under our current legal regime, property rights and accompanying due process protections derive froun discretion-constraining standards. Likewise, standing to enforce statutory protections also hinges on the creation of enforceable, clearly defined rights. Simply put, constitutional and statutory due process rights were conceived as constraints on governmental abuse of power. When private actors fill public shoes, these doctrines no longer fit.

Accountability in a privatized scheme could be heightened by strengthening and expanding existing doctrines. Every branch of government could potentially play a role in securing the rights of welfare beneficiaries. For instance, legislators could enact express rights of action to enforce fair procedures, and in so doing, reduce their own enforceinent burden while ensuring equitable treatment for our most disenfranchised citizens. ${ }^{403}$ Yet legislatures have been largely unsyınpathetic to the rights of the poor. While the state TANF laws pay lip service to fair procedures, there seems to be a prevailing attitude that the poor are lucky to get any assistance, and that they should therefore swallow the "bitter with the sweet." Legislatures could also expand the reach of administrative procedure acts and mandamus statutes to include certain types of private contractors, although such expansion would surely be costly and perhaps undermine the perceived cost savings of privatization. Separate from legislative solutions, local governments entering into valuable contracts with

403. In this regard, it should be noted that TANF will have to be reauthorized in 2002, and lengthy policy debates about TANF reform are expected at that time. See Barry L. Van Lare \& Gretchen Griener, Reauthorization of TANF-An Early Perspective, Issue Notes (July 2000), available at http://www.welfareinfo.org/issuenotereauthorization.htm. 
private entities could negotiate favorable terms for welfare recipients and provide express rights of enforcement by third-parties. Again, however, it is not clear that welfare beneficiaries have the political capital necessary to pressure local governments to negotiate on their behalf.

Throughout this century, the courts have largely been the defenders of the rights of the poor, and perhaps now, more than ever, their vigilance is necessary. A more robust state action doctrine, faithful to the doctrine's underlying purposes, could encompass government contractors who distribute public entitlements, and thereby ensure that constitutional protections are provided to welfare claimants in privatized jurisdictions.

Privatization has been heralded as the cure to many government ills. For certain, discrete municipal services, privatization may indeed be the necessary salve. However, the empirical evidence strongly suggests that privatization is not likely to improve upon government performance in complex social service arenas such as welfarc. Moreover, welfare claimants may end up worse off than they are under even the dreariest of governmental bureaucracies. As a nation, we have embarked on a bold experiment, but we have jumped in headfirst, with scant attention to the legal implications of this shift. Not surprisingly then, the legal rights of the poor have fallen by the wayside. 